Prepared in cooperation with the

Southwest Florida Water Management District and

Tampa Bay Water

\title{
Factors that Influence the Hydrologic Recovery of Wetlands in the Northern Tampa Bay Area, Florida
}

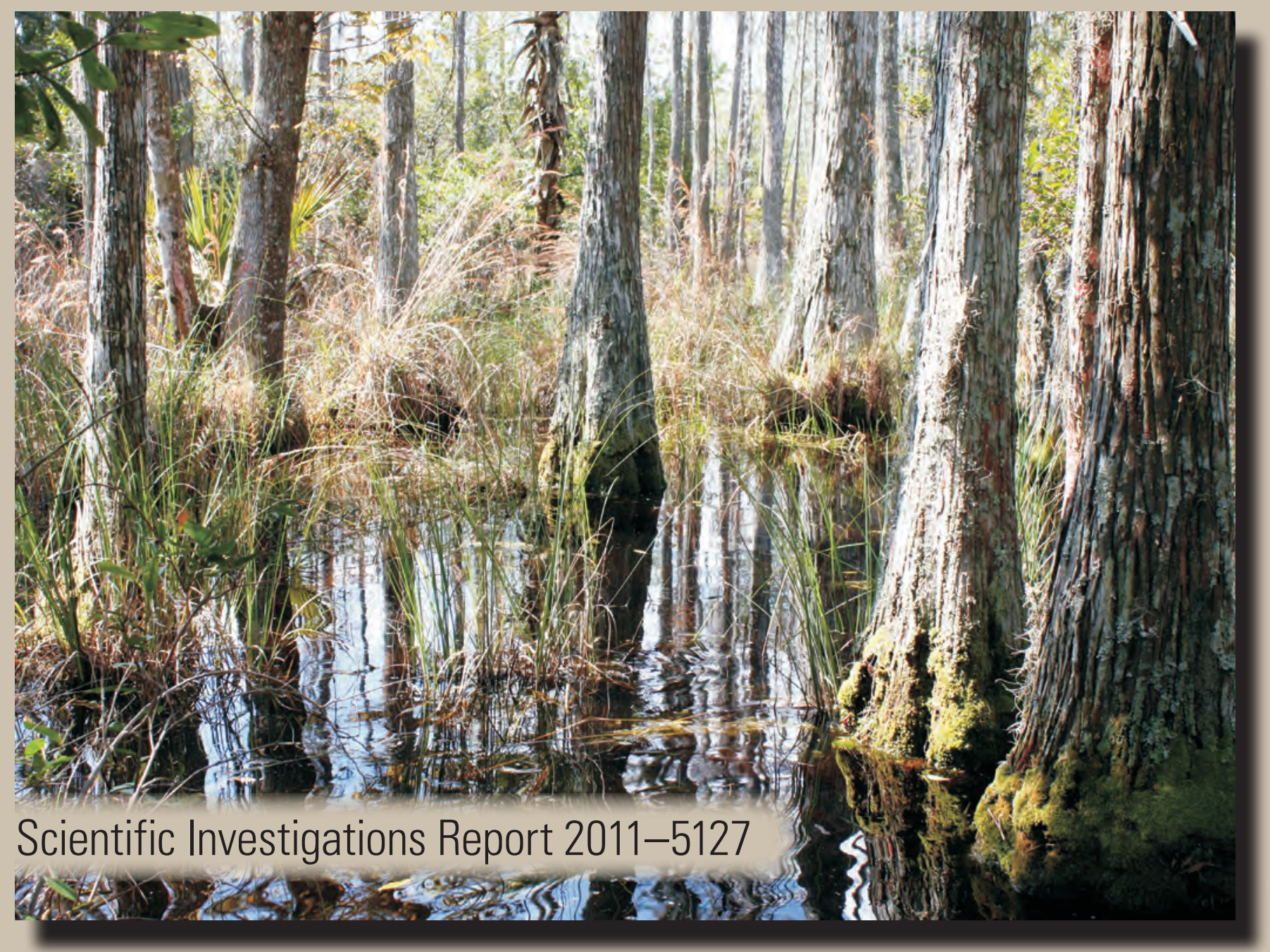

U.S. Department of the Interior U.S. Geological Survey 
On the Cover: W-33 Cypress wetland, Cypress Creek well field.

Opposite page: S-68 Cypress wetland, Starkey well field.

Photographs taken by the author, P.A. Metz. 


\section{U.S. Department of the Interior \\ KEN SALAZAR, Secretary \\ U.S. Geological Survey \\ Marcia K. McNutt, Director}

U.S. Geological Survey, Reston, Virginia: 2011

For more information on the USGS - the Federal source for science about the Earth, its natural and living resources, natural hazards, and the environment, visit http://Www.usgs.gov or call 1-888-ASK-USGS.

For an overview of USGS information products, including maps, imagery, and publications, visit $h t t p: / / w w w . u s g s . g o v / p u b p r o d$

To order this and other USGS information products, visit http://store.usgs.gov

Any use of trade, product, or firm names is for descriptive purposes only and does not imply endorsement by the U.S. Government.

Although this report is in the public domain, permission must be secured from the individual copyright owners to reproduce any copyrighted materials contained within this report.

Suggested citation:

Metz, P.A., 2011, Factors that influence the hydrologic recovery of wetlands in the Northern Tampa Bay area, Florida: U.S. Geological Survey Scientific Investigations Report 2011-5127, 58 p. 


\section{Acknowledgments}

The author acknowledges Southwest Florida Water Management District (SWFWMD) employees Michael Hancock for his help with the study wetland selection and for his constructive technical discussions and review comments, Robert Peterson for his help in compiling groundwater withdrawal data for the Northern Tampa Bay well fields, and Vince Pelham and Robert Parker for performing geophysical logging tests for several study wells. Special recognition is given to former SWFWMD employee Ted Rochow for his long-term effort in documenting the history of wetlands in the Northern Tampa Bay area.

The author also acknowledges Tampa Bay Water employees Warren Hogg and Jeff Geurink for their constructive technical review comments, and Patricia Fesmire and Chris Shea for their help with the study wetland selection. The author would like to thank Reynolds, Smith, and Hills employee Cynthia Wheeler for her assistance with initial logistics in the monitoring of the study area wetlands.

Special recognition is given to U.S. Geological Survey (USGS) employees Terrie M. Lee and Amy Swancar for their valuable technical insight during this project, and Leel Knowles, James LaBaugh, and Arturo Torres for their constructive technical review comments. The author acknowledges the assistance of Nancy DeWitt and Billy J. Reynolds of the USGS St Petersburg Coastal and Marine Science Center for the collection of vibracores at six of the study wetlands. The author also expresses gratitude for field support and data analysis provided by the USGS interns from the University of South Florida; Geoffrey Fouad, Robert Schroeder, William Pfeiffer, Scott Orr, Suzana Hernandez, and Gene Morell. 


\section{Contents}

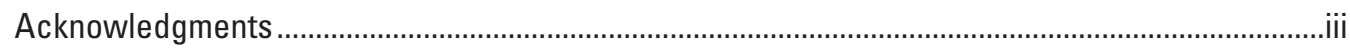

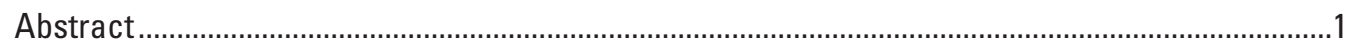

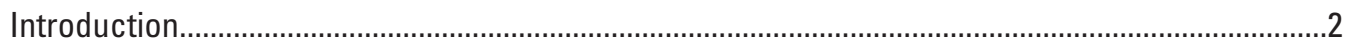

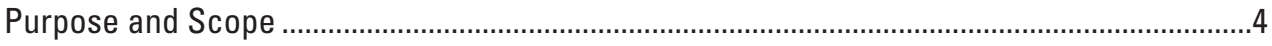

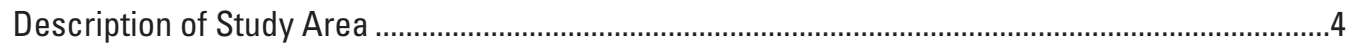

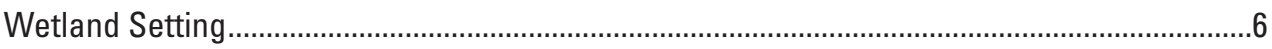

Anthropogenic Impacts on Regional Wetlands....................................................................

Description of Well Fields.........................................................................................................

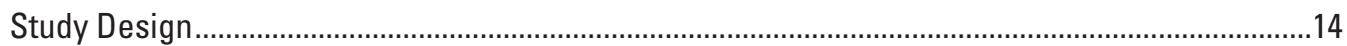

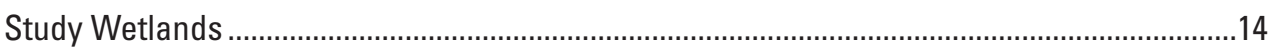

Methods of Investigation.......................................................................................................... 16

Factors that Influence the Hydrologic Recovery of Wetlands .......................................................20

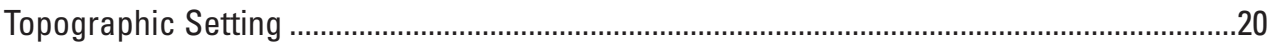

Hydrogeologic Setting ...........................................................................................................22

Permeability of Sediments Underlying the Wetlands ...................................................22

Influence of Karst Features on Wetland Hydrology.........................................................26

Potentiometric Surface of the Upper Floridan Aquifer..............................................................33

Historical Trends in Groundwater Levels...........................................................................33

Potentiometric Surface Elevations before and after Reductions in

Effects of Groundwater Withdrawals on Wetland Hydroperiods ....................................42

Ranking of Factors Influencing the Hydrologic Recovery of Wetlands.................................46

Summary. .49

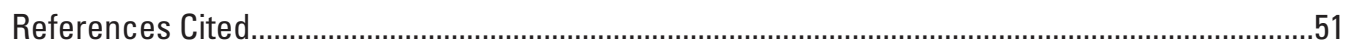

Appendix 1. Potentiometric surface map of the Upper Floridan aquifer prior to development at the Starkey and Cypress Creek well fields................................56

Appendix 2. Potentiometric surface map of the Upper Floridan aquifer at the Starkey well field for September 2008 and May 2009 ...........................................57

Appendix 3. Potentiometric surface map of the Upper Floridan aquifer at the Cypress Creek well field for September 2008 and May 2009.

\section{Figures}

1. Map showing wetland study area and the 11 consolidated well fields located in the Northern Tampa Bay area...

2. Graphs showing rainfall departures and 3-year moving average of this departure at the Tarpon Springs and Saint Leo rainfall stations for 1970-2009.

3. Diagrams showing generalized interactions of groundwater with the study wetlands, including groundwater recharge, groundwater flow-through, and groundwater discharge 
4. Aerial photographs showing isolated wetlands connecting through low-gradient surface-water drainage channels and outflow ditches from wetlands. 8

5. Graphs showing combined groundwater withdrawals from the 11 consolidated well fields, allocation for water supply in the Northern Tampa Bay area, and annual groundwater withdrawal rates for the Starkey, Cypress Creek, and Cypress Bridge well fields.

6-8. Photographs and aerial site maps showing location of the study wetlands and productions wells at the:

6. Starkey well field and individual study wetlands

7. Cypress Creek well field and individual study wetlands .

8. Cypress Bridge well field, monitoring sites and land-use development surrounding the wetland, encroachment of upland species and tree fall, and small and large sinkholes at the Cypress Bridge 01 wetland

9. Light Detection and Ranging (LIDAR) digital elevation maps showing topography surrounding the study wetlands at the Starkey and Cypress Creek well fields. .21

10. Generalized hydrogeologic sections showing an unimpacted to minimally impacted wetland, a moderately impacted wetland, and two severely impacted wetlands.

11. Photographs showing vibracore samples and graphs showing percentage of sand, silt, and clay in the upper 2 feet of wetland sediments, and clay content at and below land surface for six of the study wetlands

12. Photographs showing vibracore sample collection and core samples highlighting the variability of the clay layers in cores beneath the study wetlands.....

13. Map showing generalized thickness of the intermediate confining unit overlying the Upper Floridan aquifer

14. Geologic and natural-gamma logs showing the variability in the clay units near the study wetlands at the Cypress Creek and Starkey well fields

15. Maps showing bathymetry of severely impacted wetlands, an unimpacted wetland, and a minimally impacted wetland....

16. Maps showing bathymetry of the Cypress Bridge 01 wetland ..........................................30

17-19. Aerial photographs showing:

17. Location of sinkholes that formed in and around the Section 21 well field due to groundwater withdrawals.

18. Location of ground-penetrating radar transect lines, and geophysical profile $A-A^{\prime}$ with interpreted geologic features below Cypress Bridge 01 at the Cypress Bridge well field.

19. Location of ground-penetrating radar transect lines, and geophysical profile $D-D^{\prime}$ with interpreted geologic features below W-16 Marsh at the Cypress Creek well field.

20. Box plots showing water-level differences between the wetland/surficial aquifer and Upper Floridan aquifer for the study wetlands, 2007-08....

21. Hydrographs showing long-term water levels for the Upper Floridan aquifer and surficial aquifer at the Cypress Creek well field and surrounding areas.....

22. Hydrographs showing long-term water levels for the Upper Floridan aquifer and surficial aquifer at the Starkey well field and surrounding areas 
23-25. Maps showing elevation difference between land surface and the potentiometric surface of the Upper Floridan aquifer:

23. Prior to well-field production at the Starkey and Cypress Creek well fields.......... 38

24. During September 2008 and May 2009 at the Starkey well field................................ 39

25. During September 2008 and May 2009 at the Cypress Creek well field .................. 40

26. Box plots showing elevation of the potentiometric surface of the Upper Floridan aquifer above or below the study-wetland bottom elevations prior to and after the reductions in groundwater withdrawals at the Starkey and Cypress Creek well fields

27. Graphs showing groundwater withdrawals within a 1-mile radius of the center of the study wetlands prior to and after reductions in groundwater withdrawals..........42

28. Hydrographs of historical water levels at an unimpacted, a minimally impacted, and two severely impacted wetlands

29. Maps showing the shape of flooded areas at different levels of inundation and graphs showing duration of flooding prior to and after reductions in groundwater withdrawals at S-68 and S-44 Cypress at the Starkey well field.

30. Maps showing the shape of flooded areas at different levels of inundation and graphs showing duration of flooding prior to and after reductions in groundwater withdrawals at W-33 Cypress and W-16 Marsh at the Cypress Creek well field.

31. Graph showing total ranking of factors that influence the hydrologic recovery of wetlands in the Northern Tampa Bay area

\section{Tables}

1. Name, location, and other characteristics of the study wetlands

2. Methods used to describe the factors affecting the hydrologic condition and recovery of each study wetland. $\ldots 17$

3. Well characteristics and other data collected at the study wetlands 18-19

4. Relation between surficial and Upper Floridan aquifer levels at the study wetlands

5. Ranking of the study wetlands based on the factors that influence the hydrologic recovery of wetlands in the Northern Tampa Bay area. 


\title{
Conversion Factors
}

Inch/Pound to SI

\begin{tabular}{|c|c|c|}
\hline Multiply & By & To obtain \\
\hline \multicolumn{3}{|c|}{ Length } \\
\hline inch (in.) & 2.54 & centimeter $(\mathrm{cm})$ \\
\hline inch (in.) & 25.4 & millimeter $(\mathrm{mm})$ \\
\hline foot $(\mathrm{ft})$ & 0.3048 & meter $(\mathrm{m})$ \\
\hline mile (mi) & 1.609 & kilometer (km) \\
\hline \multicolumn{3}{|c|}{ Area } \\
\hline acre & 4,047 & square meter $\left(\mathrm{m}^{2}\right)$ \\
\hline acre & 0.4047 & hectare (ha) \\
\hline square mile $\left(\mathrm{mi}^{2}\right)$ & 2.590 & square kilometer $\left(\mathrm{km}^{2}\right)$ \\
\hline \multicolumn{3}{|c|}{ Volume } \\
\hline gallon (gal) & 3.785 & liter $(\mathrm{L})$ \\
\hline gallon (gal) & 0.003785 & cubic meter $\left(\mathrm{m}^{3}\right)$ \\
\hline million gallons (Mgal) & 3,785 & cubic meter $\left(\mathrm{m}^{3}\right)$ \\
\hline acre-foot (acre-ft) & 1,233 & cubic meter $\left(\mathrm{m}^{3}\right)$ \\
\hline \multicolumn{3}{|c|}{ Flow rate } \\
\hline gallon per day (gal/d) & 0.003785 & cubic meter per day $\left(\mathrm{m}^{3} / \mathrm{d}\right)$ \\
\hline inch per year (in/yr) & 25.4 & millimeter per year (mm/yr) \\
\hline million gallons per day (Mgal/d) & 0.04381 & cubic meter per second $\left(\mathrm{m}^{3} / \mathrm{s}\right)$ \\
\hline \multicolumn{3}{|c|}{ Hydraulic conductivity } \\
\hline foot per day $(\mathrm{ft} / \mathrm{d})$ & 0.3048 & meter per day $(\mathrm{m} / \mathrm{d})$ \\
\hline \multicolumn{3}{|c|}{ Leakage } \\
\hline inch per day (in/d) & 2.54 & centimeter per day $(\mathrm{cm} / \mathrm{d})$ \\
\hline
\end{tabular}

Vertical coordinate information is referenced to the National Geodetic Vertical Datum of 1929 (NGVD 1929).

Horizontal coordinate information is referenced to the North American Datum of 1983 (NAD 83).

Elevation, as used in this report, refers to distance above the vertical datum.

\section{Acronyms and Additional Abbreviations}

\author{
GIS geographic information system \\ GPR ground-penetrating radar \\ LIDAR Light Detection and Ranging \\ NOAA National Oceanic and Atmospheric Administration \\ NWI National Wetland Inventory \\ SWFWMD Southwest Florida Water Management District \\ USGS U.S. Geological Survey \\ WAP Wetland Assessment Procedure \\ $<$ less than \\ $>$ greater than
}



in the Northern Tampa Bay Area,

Florida

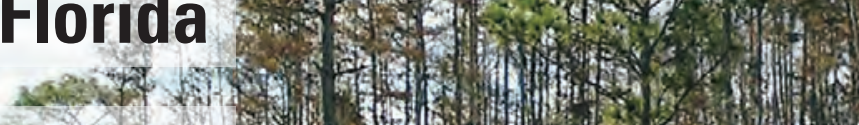

By P.A. Metz
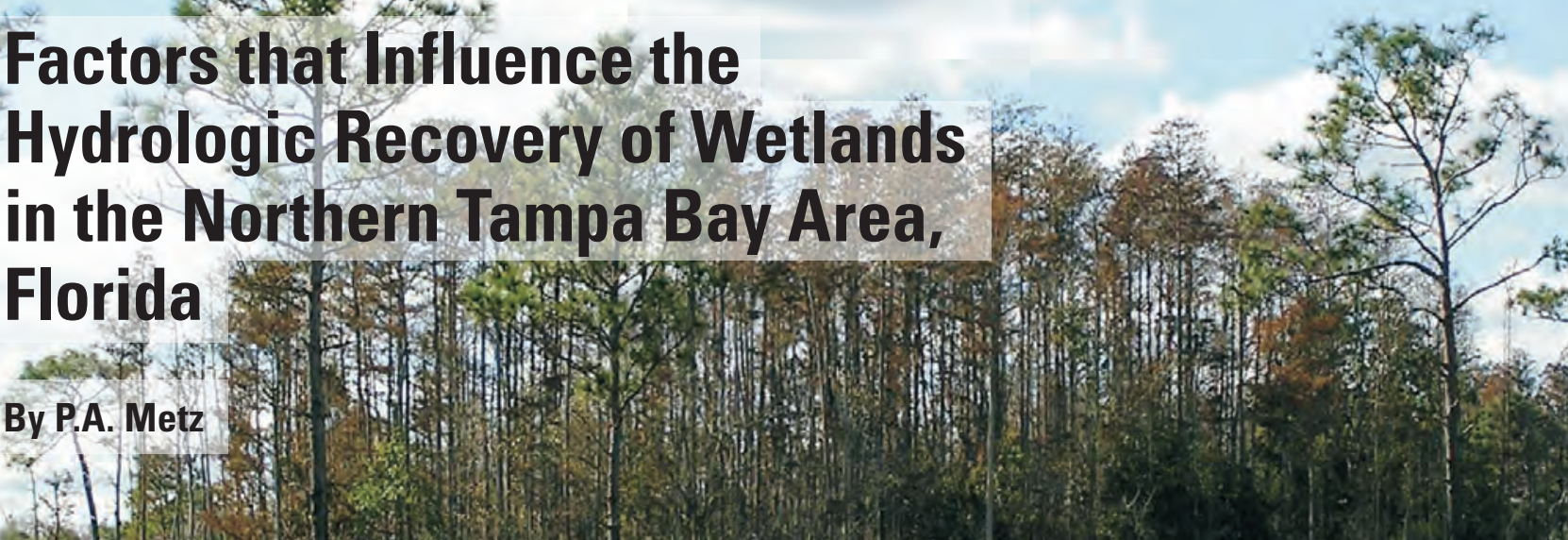

Reductions in groundwater withdrawals from Northern Tampa Bay well fields were initiated in mid-2002 to improve the hydrologic condition of wetlands in these areas by allowing surface and groundwater levels to recover to previously higher levels. Following these reductions, water levels at some long-term wetland monitoring sites have recovered, while others have not recovered as expected. To understand why water levels for some wetlands have not increased, nine wetlands with varying impacts from well field pumping were examined based on four factors known to influence the hydrologic condition of wetlands in west-central Florida. These factors are the level of the potentiometric surface of the Upper Floridan aquifer underlying the wetland, recent karst activity near and beneath the wetland, permeability of the underlying sediments, and the topographic position of the wetland in the landscape.

The combination of two factors, the presence of recent karst activity below or near the wetlands and the depth to the potentiometric surface of the Upper Floridan aquifer below the wetlands, had the most influence on the hydrologic recovery of the study wetlands. The study wetlands are located in an area where numerous localized surface or buried depressions (karst features or sinkholes) are common throughout the mantled karst landscape, which increases the hydrologic connection between the wetlands and the underlying aquifers. Breaches or breaks in the underlying sediments or in the intermediate confining unit due to recent karst subsidence activity act as pathways for downward leakage. For the study wetlands, the leakage potential increased when the vertical separation between the potentiometric surface of the Upper Floridan aquifer and the wetland-bottom elevation (a surrogate for the wetland water level) increased.
The increase in the potentiometric surface of the Upper Floridan aquifer below the wetland was the primary factor influencing the hydrologic recovery of the study wetlands, even in areas affected by karst subsidence. For one of the study wetlands influenced by karst subsidence (S-44 Cypress at Starkey well field), the potentiometric surface of the Upper Floridan aquifer increased to the level of the wetland-bottom elevation following the reductions in groundwater withdrawals. Despite the karst subsidence in the wetland, having the level of the potentiometric surface just below the wetland bottom limited the downward leakage potential and resulted in an increase in the flooded area and duration of the wetland hydroperiod.

In contrast, two study wetlands affected by karst subsidence (W-12 Cypress and W-16 Marsh at Cypress Creek) remained mostly dry during the period of groundwater withdrawal reductions, even though the median elevation of the potentiometric surface of the Upper Floridan aquifer rose about 5 feet in this area of the well field. These wetlands are located in an area of the well field where large groundwater withdrawals are concentrated, and during the last 20 years (1989-2009) the wetlands were inundated only during periods of extreme rainfall. During these brief inundation periods, the wetland water levels receded after 1 to 2 months, much more rapidly than wetlands located in areas without karst subsidence or concentrated pumping, indicating the increased leakage between the wetlands and underlying aquifers. Because of this interconnection, water levels in these wetlands and others impacted by karst subsidence in this region will not recover if the potentiometric surface of the Upper Floridan aquifer remains at its current (2009) elevation (median distance of about 10 feet below the wetland-bottom elevation). 
Low permeability sediments and the absence of karst features underlying the wetlands had a positive influence on the wetland recovery following the reductions in groundwater withdrawals. In these settings, intact low permeability subsurface layers help maintain water within and beneath the wetland, and limit the downward leakage potential to the Upper Floridan aquifer. For wetlands in these settings, the increase in potentiometric surface of the Upper Floridan aquifer below the study wetland-bottom elevations resulted in an increase in the flooded area and the duration of the wetland hydroperiod.

Although of less importance than the other three factors, a low-lying topographical position benefited the hydrologic condition of several of the study wetlands (S-68 Cypress and $\mathrm{W}-12$ Cypress) both before and after the reductions in groundwater withdrawals. Compared to wetlands in a higher topographical position, those in a lower position had longer hydroperiods because of their greater ability to receive more runoff from higher elevation wetlands and to establish surfacewater connections to other isolated wetlands and surface-water bodies through low-lying surface-water channels during wet conditions. In addition, wetlands in low-lying areas benefited from groundwater inflow when groundwater levels were higher than wetland water levels.

\section{Introduction}

Groundwater use in the Northern Tampa Bay area has increased steadily since the 1930s, and by the early 2000s, groundwater was withdrawn for public supply from the Upper Floridan aquifer at an average annual rate of 165 million gallons per day (Mgal/d) (Robert Peterson, Southwest Florida Water Management District, written commun., 2009). Groundwater is the major component of the water supply for the Northern Tampa Bay area, and most of this groundwater is withdrawn from 11 consolidated well fields managed by the regional utility, Tampa Bay Water (fig. 1). Due to the long-term groundwater withdrawals from the well fields, the potentiometric surface of the Upper Floridan aquifer has been lowered within and around the well fields in the Northern Tampa Bay area (Hutchinson, 1984; Southwest Florida Water Management District, 1996). Surface-water bodies generally are well-connected to the groundwater system in the Northern Tampa Bay area, and water-level declines have also been observed in many lakes and wetlands in the areas around the well fields (Metz and Sacks, 2002; Lee and others, 2009). For some of the wetlands in these areas, water-level declines have reduced the length of time these wetlands contain standing water (wetland hydroperiod), and in some cases have caused extensive damage to wetland ecosystems (Dooris and others, 1990; Rochow, 1998; Lee and others, 2009).

Most of the well fields in the Northern Tampa Bay area are located on undeveloped tracts of land that contain many acres of isolated cypress domes, freshwater marshes, and wet prairies (Rochow, 1998). The Southwest Florida
Water Management District (SWFWMD) has established minimum surface-water levels in areas where groundwater withdrawals have contributed to or have the potential to create substantial harm to wetland ecosystems (Southwest Florida Water Management District, 1999a,b). Currently (2009), a number of wetlands in and around the well fields are below their established minimum levels and a decline in the health of many wetlands has been observed (Mike Hancock, Southwest Florida Water Management District, unpub. data, 2009).

In response to lowered groundwater, lake, and wetland water levels, efforts have been made to reduce the reliance on groundwater for public-water supply. With the reduction in groundwater use, river and desalinated water have served as supplementary resources (Tampa Bay Water, 2010b). In addition, water conservation and reuse measures have been implemented to further reduce overall water use and reliance on groundwater (Southwest Florida Water Management District, 2009). Reductions in groundwater withdrawals began in mid-2002, and the average annual groundwater withdrawn from the 11 well fields decreased from about $130 \mathrm{Mgal} / \mathrm{d}$ in 2002 to about $96 \mathrm{Mgal} / \mathrm{d}$ during 2003-09 (Robert Peterson, Southwest Florida Water Management District, written commun., 2009).

Because of the reductions in groundwater withdrawals, groundwater levels surrounding some of the previously impacted wetlands have increased and some of the wetlands may return to naturally functioning ecosystems. Based on historical benchmark levels, however, water levels in a number of wetlands have not rebounded as expected (Mike Hancock, Southwest Florida Water Management District, unpub. data, 2009). To address this issue, the U.S. Geological Survey initiated a 2-year study in 2007 to characterize the factors that influence the general hydrologic condition of wetlands and the recovery of water levels for wetlands impacted by well-field pumping in the Northern Tampa Bay area. The study was conducted in cooperation with the Southwest Florida Water Management District and Tampa Bay Water. Four factors known to influence the hydrologic condition of the wetlands in west-central Florida were examined at selected wetlands during the study: the topographic setting, the permeability of the underlying sediments, recent karst activity, and the depth to the potentiometric surface of the Upper Floridan aquifer underlying the wetlands. This analysis provided an indication of the hydrologic condition of each wetland and identified which factors limit the increase in wetland water levels. Reducing pumping is expected to raise wetland water levels by raising groundwater levels and decreasing the distance of the potentiometric surface below wetlands, but it will have little direct effect on the other three factors. For this reason, all four factors need to be examined to understand why the water levels in some wetlands have not increased as expected.

The data collected and knowledge gained during this investigation provide an understanding of the factors affecting wetland water levels in relation to the elevation of the potentiometric surface of the Upper Floridan aquifer in a 


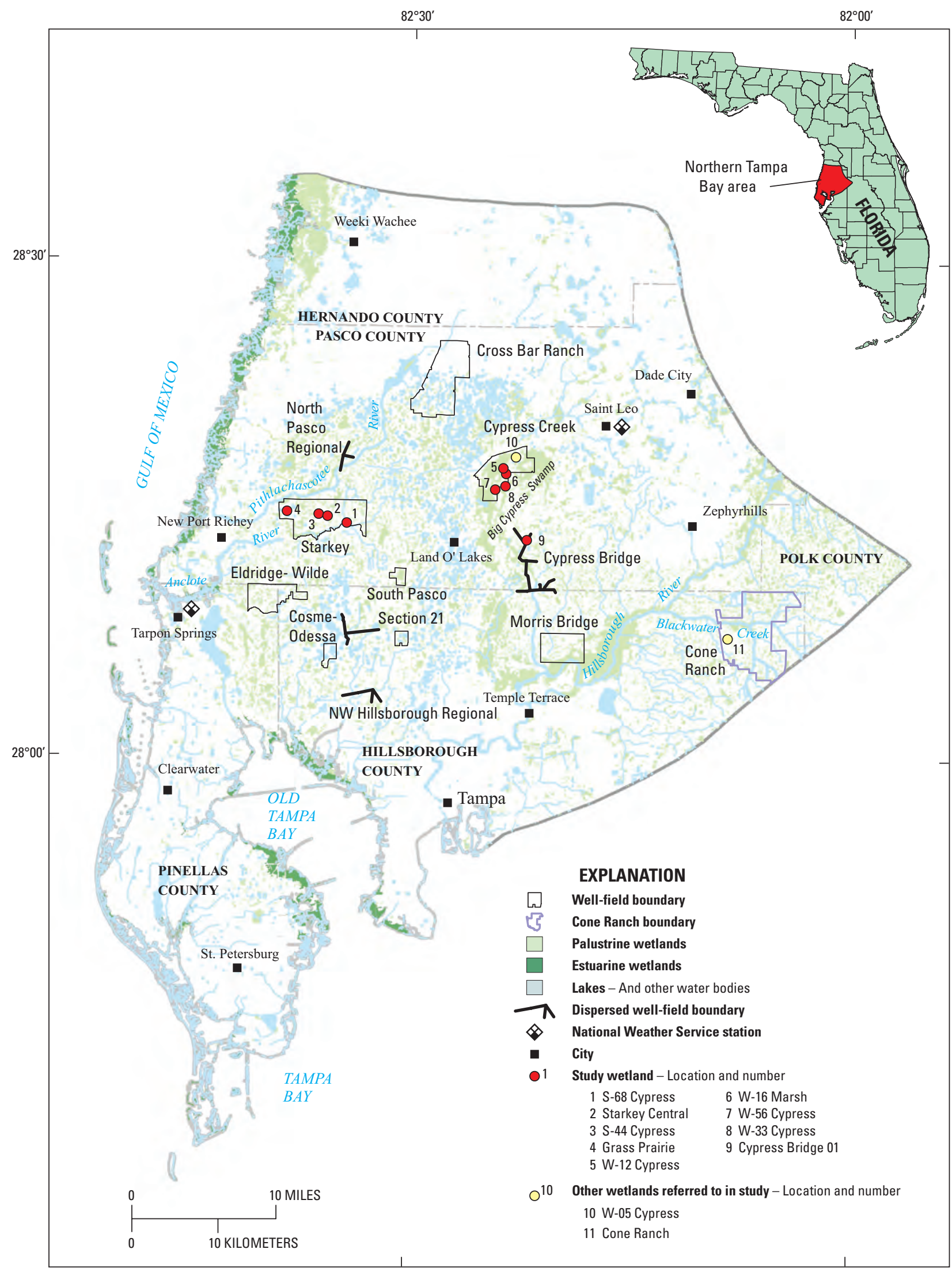

Figure 1. Wetland study area and the 11 consolidated well fields located in the Northern Tampa Bay area. 
karst hydrogeologic setting. A broader understanding of the interaction between surface water, groundwater, and wetland ecosystems is an important component of the USGS Strategic Plan. Understanding the issues of surface-water response to groundwater withdrawals, and groundwater recharge responses to surface-water management changes is vital to the protection and management of wetland ecosystems in the Northern Tampa Bay area.

\section{Purpose and Scope}

The purpose of this report is to document the effects of four factors known to influence the hydrologic condition of the wetlands in west-central Florida, namely, the topographic setting, the permeability of underlying sediments, recent karst activity, and the depth to the potentiometric surface of the Upper Floridan aquifer underlying the wetland. The study wetlands included a relatively unimpacted wetland and eight wetlands with documented impacts from well-field pumping located at Starkey, Cypress Creek, and Cypress Bridge well fields (fig. 1). This report also evaluates how each of these factors has affected the hydrology of the nine wetlands following the reduction of groundwater pumping.

Comparisons and analyses of the nine study wetlands were made using hydrologic, vegetation, bathymetric, geophysical, geologic, and land-surface elevation data. Historical data from 1975 to 2009 were compiled for this investigation, and consisted of surface-water and groundwater levels, groundwater withdrawal rates, rainfall amounts, and geologic, vegetation, and soil data. These data were collected by the USGS, SWFWMD, Tampa Bay Water, National Oceanic and Atmospheric Administration (NOAA), and private consultants. Additional data used for analysis were collected by the USGS from November 2007 to May 2009 as part of this study, and consisted of surface-water and groundwater-level data, precipitation data, and geologic, geophysical, and bathymetric data.

\section{Description of Study Area}

The Northern Tampa Bay study area covers about 1,800 square miles $\left(\mathrm{mi}^{2}\right)$ and includes all of Pinellas County, and parts of Pasco, Hernando, Hillsborough, and Polk Counties (fig. 1). The population in the area has increased from 1.1 million in 1980 to an estimated 2.4 million in 2009 (U.S. Census Bureau, 2002; Tampa Bay Water, 2010a). Despite the increased use of surface water, the area continues to rely on groundwater withdrawn from regional well fields for almost half of the public supply.

The topography of the Northern Tampa Bay area is characterized by flat, marshy lowlands along the coast, low rolling hills in the central region, and sand ridges and terraces of up to $200 \mathrm{feet}$ (ft) in elevation in the northern and eastern regions. Much of the recharge to the study area occurs along these sand ridges and terraces (Southwest Florida Water Management District, 1993). Hundreds of lakes, wetlands, and marshes are interspersed throughout the study area, and range from less than 1 acre to more than 2,500 acres in extent (Haag and Lee, 2010). The majority of residential and commercial land use is concentrated along the coast and in the southern part of the study area near Tampa Bay, whereas the majority of the freshwater wetlands are scattered throughout the central and eastern regions of the study area (Metz and others, 2007). Groundwater withdrawals are concentrated in areas that contain numerous wetlands and small tributary streams that have wetlands as headwaters.

The regional hydrogeologic setting of the Northern Tampa Bay area is one of a mantled karst landscape. Such areas are characterized by a thick sequence of weathered limestone, overlain by a clay layer 0 - to $200-\mathrm{ft}$ thick, overlain by a sequence of sand 10- to 100-ft thick (Southwest Florida Water Management District, 1996). The landscape contains sinkhole depressions ranging in their period of development from older stable depressions to recent collapsed features (Sinclair, 1982). The older shallow surface depressions commonly contain swamps, marshes, or cypress domes, the latter of which are one of the most characteristic vegetative and geomorphic features in the study area (Sinclair, 1982). The deeper depressions form sinkhole lakes (Metz and Sacks, 2002).

The broad range of karst development in the study area is reflected by varying degrees of hydraulic connection between the wetlands and underlying aquifers. The shallow hydrogeologic system in the study area consists of, in descending order: the unconfined surficial aquifer system, the intermediate confining unit, and the Upper Floridan aquifer. The surficial aquifer system in this area consists of unconsolidated to poorly indurated clastic deposits of sand and clayey sand (Southeastern Geological Society, 1986). Commonly, this unit is called the surficial aquifer system where more than one permeable zone is present or where the deposits are interbedded. In this report, these deposits are considered to form a single homogeneous aquifer and are referred to as the surficial aquifer. Sediments that compose this unit consist of silt, sand, and clay that range in thickness from less than $10 \mathrm{ft}$ in coastal areas to over $100 \mathrm{ft}$ along sandy ridges (Southwest Florida Water Management District, 1996). Recharge to the water table within the surficial aquifer is relatively rapid because the surficial sands are generally permeable and the water table is close to land surface. Although water recharged to the surficial aquifer can move laterally along short flow paths to points of discharge, most of the water leaks downward through the underlying intermediate confining unit (where present) to the Upper Floridan aquifer.

The intermediate confining unit is a non-water-yielding stratum that consists of a dense, marine green-gray plastic clay that contains varying amounts of sand and carbonate mud. The clay unit is variable in extent, permeability, and thickness throughout the study area (Sinclair, 1974). Although the intermediate confining unit impedes downward flow between the surficial aquifer and Upper Floridan aquifer, the 
hydraulic connection between the aquifers is compromised in areas where the intermediate confining unit is thin, permeable, contains sand filled conduits (piping features), or is breached by sinkhole development (Stewart and Parker, 1992).

The Upper Floridan aquifer consists of a series of carbonate units and is the primary source of water supply in the study area. The limestone and dolomite of the Upper Floridan aquifer contain many solution-enlarged fractures and typically yield large quantities of groundwater to public and private wells (Metz and Sacks, 2002). Groundwater within this aquifer is pressurized or under artesian conditions, except in the extreme northern part of the Northern Tampa Bay area (Southwest Florida Water Management District, 1996). The general direction of regional groundwater flow is west to southwest towards the Gulf of Mexico, but is locally modified by major centers of groundwater withdrawals, including municipal well fields and industrial and agricultural withdrawals.

Warm, wet summers and relatively mild, dry springs typically characterize the subtropical climate of the study area. Long-term average annual rainfall recorded at the National Weather Service Tarpon Springs (1892-2009) and Saint Leo (1895-2009) stations in Florida was about 52 and 55 inches (in.), respectively (National Oceanic and Atmospheric Administration, 2010; station locations shown in fig. 1). Typically, rainfall totals at both stations are lowest in November, followed by December, April, and January; totals are highest in July, followed by June, August, and September. Rainfall during the wet season (June through September) accounts for more than half of the total annual rainfall.

Cumulative rainfall departures at the two rainfall sites (Tarpon Springs and Saint Leo, Florida; fig. 2) during a 40-year period (1970-2009) were used to help determine when relative wet and dry periods occurred in the study area prior to and during well-field production at the study well fields. Departures from the long-term average annual rainfall for 1970 to 2009 indicate that rainfall was below average for 21 and 27 years out of the 40-year period for Tarpon Springs and Saint Leo rainfall sites, respectively (fig. 2). The minimum annual average rainfall for Tarpon Springs occurred in 2007 and was about 17 in. below average; the minimum for Saint Leo occurred in 2000 and was about 16 in. below average. The maximum average annual rainfall for both stations occurred in 1983, and totaled about 23 and 20 in. above the annual averages for Tarpon Springs and Saint Leo, respectively.

A 3-year moving average of the cumulative rainfall departure was used to help determine the duration and magnitude of wet or dry periods for the two rainfall stations (fig. 2). Based on the 3-year moving average at Tarpon Springs rainfall station, the wettest period occurred during 1984, and the driest period occurred during 2007. Based on the 3-year moving average at the Saint Leo rainfall station, the wettest period occurred during 2004, which was the culmination of 3 years of above average rainfall that included several hurricanes and tropical storms in 2004. Two similar low rainfall periods occurred at Saint Leo station during 2001 and 2008 due to 3 and 4 years of below average rainfall, respectively. For a number of wells with long-term record (1949-2009) throughout the study area, the lowest groundwater levels occurred after extended dry periods in 2000-2002, and 2007 (http://wdr.water.usgs.gov/wy2009/search.jsp).

In addition to rainfall, evaporation and evapotranspiration partly determine the hydrology of wetlands in the study area. Evaporation rates are relatively high in Florida and are higher than most areas of the country (Farnsworth and others, 1982). The high evaporation rates in this subtropical climate are primarily due to high solar radiation and water temperatures. Long-term annual estimates of shallow lake evaporation range from 48 to 59 in. in central Florida and can vary depending on climatic conditions (Amy Swancar, U.S. Geological Survey,
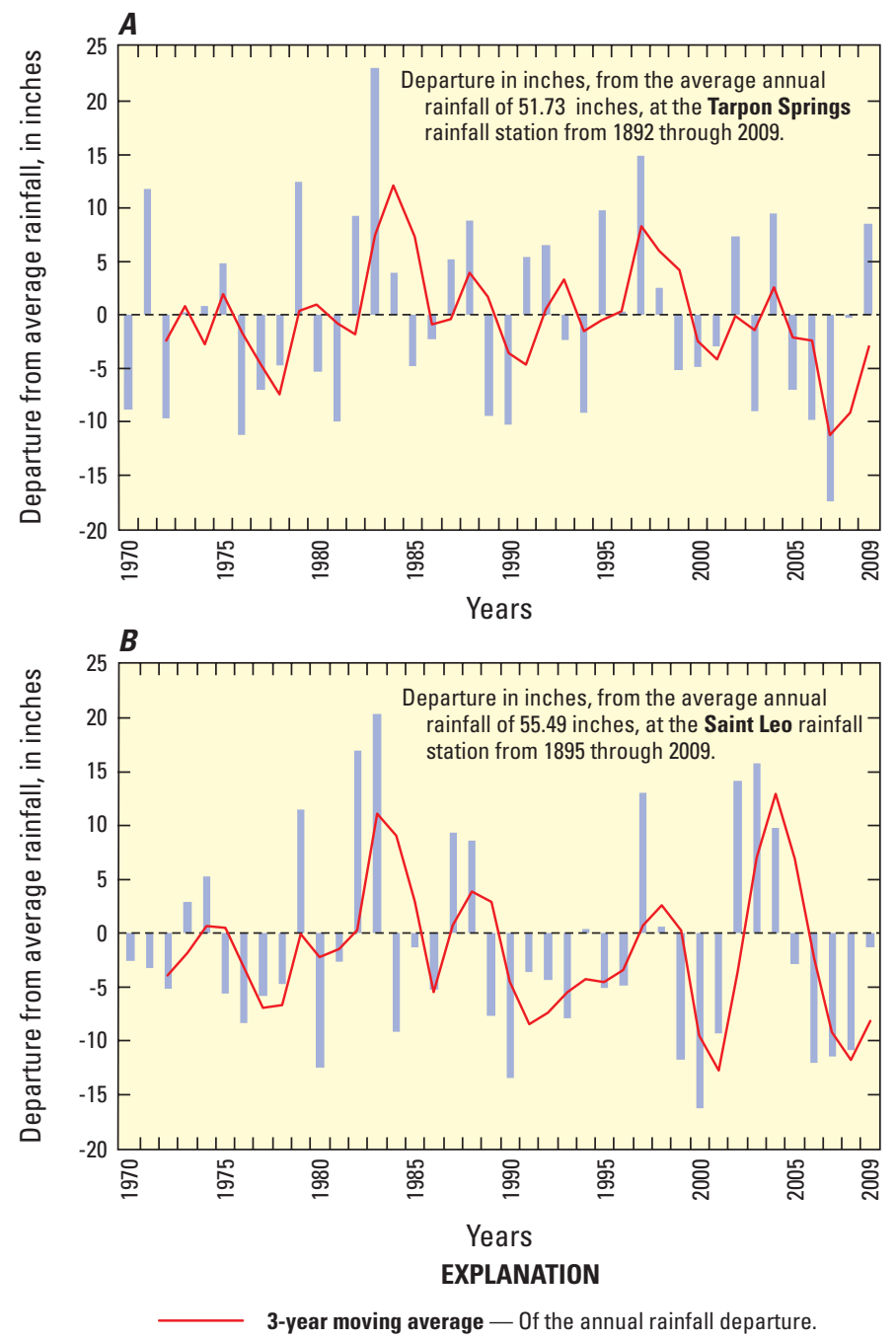

Figure 2. Rainfall departures and 3-year moving average of this departure at the $A$, Tarpon Springs and $B$, Saint Leo rainfall stations for 1970-2009. Locations of the rainfall stations are shown in figure 1. 
written commun., 2010). The annual evapotranspiration rate for cypress wetlands is about 38 inches per year (in/yr) (Bidlake and others 1996; Sumner, 2001).

Although rainfall and evaporation can vary among wetlands and rainfall dominates wetland water-budgets over short time periods (Sumner, 2006; Lee and others, 2009), atmospheric factors are assumed to affect all wetlands in this region equally over long time periods. All Northern Tampa Bay area wetlands are more likely to be dry during droughts and to flood during wet years, but how individual wetlands respond to reductions in groundwater withdrawals is more a function of differences in their physical and hydrogeologic settings than differences in climate.

\section{Wetland Setting}

More than 33,000 wetlands are located throughout the Northern Tampa Bay area with the majority (81 percent) consisting of freshwater wetlands (Southwest Florida Water Management District, 2004; fig. 1). The numerous wetlands in the study area are widely distributed, relatively small, and are typically isolated. In many places, wetlands are surrounded by uplands, forming a mosaic of contrasting environments. These wetlands typically contain unique wildlife habitat that is often adjacent to dense human development (Haag and Lee, 2010). The relatively small size and vast numbers of wetlands challenge efforts to characterize them collectively as a statewide water resource (Lee and Haag, 2006).

The Northern Tampa Bay area contains a variety of freshwater wetland types; the most common in the study area are floodplain wetlands, cypress domes, marshes, and wet prairies (Rochow, 1998; Southwest Florida Water Management District, 2004). The floodplain wetlands consist of more than one wetland type, and may include both mixed-hardwood and cypress swamp forests. The cypress domes in the study area are dominated by pond cypress trees (Taxodium ascendens), which form the characteristic dome-shaped profile. Marshes and wet prairies are mostly treeless wetlands that support a diverse assemblage of grasses, sedges, and forbs (Rochow, 1998). These wetland types are typically surrounded by upland pine flatwoods.

Three general groundwater flow conditions were observed at the study wetlands based on the seasonal configuration of water levels in the surficial aquifer and Upper Floridan aquifer relative to the wetland levels.

The most commonly observed condition was groundwater recharge, indicated by downward leakage from the wetland into the underlying aquifers (fig. $3 A$ ). This condition exists when water levels in a wetland are generally higher than the levels in the surficial aquifer, allowing water to leak into and recharge the underlying aquifers. The next most common condition, groundwater flow-through, was observed at several study wetlands. This condition is indicated by simultaneous groundwater inflow and outflow along different parts of a wetland perimeter (fig. $3 B$ ). The third flow condition, groundwater discharge, occurred during wet conditions when
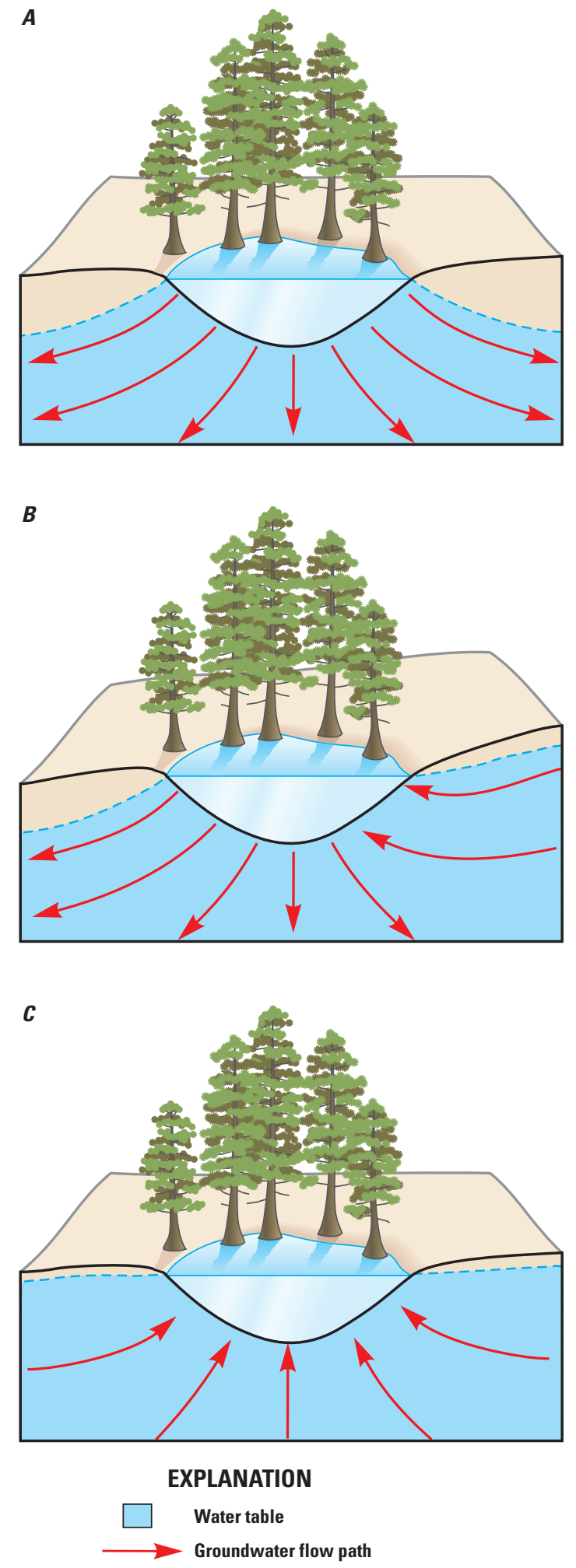

Figure 3. Generalized interactions of groundwater with the study wetlands, including $A$, groundwater recharge; $B$, groundwater flow-through, and $C$, groundwater discharge. Modified from Winter and others (1998) and Lee and others (2009). 
the potentiometric surface of the Upper Floridan aquifer was generally at or slightly above land surface, which limited the downward leakage potential from the surficial aquifer and wetland (fig. 3C).

The typical annual water-level pattern for isolated wetlands in the study area includes two wet periods (summer and winter) and two dry periods (spring and fall) (Carr and others, 2006). Wetlands in the study area commonly follow a hydrologic pattern in which water levels decline during the spring dry period and reach a minimum in May and June (Lee and others, 2009). During the dry season, the water table remains below land surface, forming a shallow groundwater mound beneath the wetland bottom. Wetland water levels typically begin rising during the summer rainy season and reach a maximum in September (Berryman and Hennigar, Inc., 2000; Lee and others, 2009).

During years with average rainfall, unimpacted marshes and cypress wetlands typically contain standing water (and thus have a hydroperiod of) more than 6 months per year (Ewel and Wickenheiser, 1988). For a shallow, unimpacted cypress wetland located in the study area (S-68 Cypress), the 19-year average hydroperiod was 235 days, or the wetland contained standing water during 63 percent of the year and was dry during 37 percent of the year (Lee and others, 2009). The hydroperiod of wetlands in the study area is largely determined by the difference between precipitation and evapotranspiration, but also is influenced by the elevation of the potentiometric surface of the Upper Floridan aquifer. When aquifer levels decline in the Upper Floridan aquifer because of groundwater withdrawals or sustained drought, the decline induces downward leakage from the overlying surficial aquifer, which in turn decreases wetland water levels (Metz and Sacks, 2002; Lee and others, 2009). A small $(<0.5 \mathrm{ft})$ change in wetland water levels resulting from groundwater withdrawals or climatic conditions can cause large changes in wetland surface area, because these wetlands are situated in relatively shallow topographic depressions (Lee and others, 2009).

\section{Anthropogenic Impacts on Regional Wetlands}

The numerous wetlands in the Northern Tampa Bay area provide important environmental functions in regards to the contribution and maintenance of baseflow to streams, recharge to the groundwater system, flood control, waterquality enhancements, and wildlife habitat and breeding grounds (Haag and Lee, 2010). In the rapidly developing area of Northern Tampa Bay, the hydrology and ecology of these wetlands have been affected by anthropogenic activities such as urban and agricultural development, construction of roadways and ditches, and large groundwater withdrawals in surrounding areas. Understanding the impacts of wetland loss and wetland responses to anthropogenic activities is necessary for effectively managing this important resource.
The first wetland inventory in Florida, completed in 1845 , indicated that wetlands composed 59 percent of the State; by 1996, wetlands composed only 29 percent of the State (Dahl, 1990, 2000, 2005, and 2006). The loss of wetlands in Florida has primarily been attributed to the conversion of wetlands to agricultural and urban lands (Tiner, 1984; Pittman and Waite, 2009). Other reasons for the loss of wetlands include flood control, forestry, road development, and mosquito control (Carter, 1986; Dahl, 1990; Frayer and Hefner, 1991). Although wetland mitigation banks have been used in the past decade to offset wetland loss, the methods and accounting systems for these losses have not been fully understood and further research is needed (Reiss and others, 2009). The examples that follow briefly explain how changes in surface-water flow patterns, land-use changes, ditching, and groundwater withdrawals have affected the hydrology of wetlands in the study area.

Runoff or surface-water inflow to wetlands has played a major role in the hydrology of some of the wetlands in the Northern Tampa Bay area. Water-budget analyses conducted by Lee and others (2009) provided insight into the importance of runoff on the hydrology of isolated wetlands. Lee and others (2009) found that overland flow from surrounding areas contributed half to almost twice as much water to some Northern Tampa Bay wetlands as direct rainfall during high rainfall events. Ewel and Odum (1984) indicated that the transition from isolated wetlands to wetland chains connected by streams usually occurs at the end of a wet season for cypress-pine flatwoods wetlands (fig. 4A). Lee and others (2009) found that all five cypress wetlands studied during the 2003-05 wet period generated an outflow stream during part of the period, and four received inflow from neighboring wetlands. Runoff estimates in the study by Lee and others (2009) emphasize the importance of preserving the linkage between wetlands and surrounding uplands to sustain the natural wetland hydrology.

The study wetlands in Lee and others (2009) were located in relatively undisturbed areas where intermittent linkages formed between isolated wetlands as well as streams and rivers. In many areas of Northern Tampa Bay area, however, land-use changes have severed these linkages. During high rainfall events, many isolated wetlands become interconnected through surface-water flow channels. Although these channels are often barely discernable on the ground because of their extremely low gradients, the "trails" between wetlands shown in figure $4 B$ provides visual evidence of these channels. Land-use changes can interfere with overland flow patterns and consequently reduce or increase surface-water inflow to wetlands, altering their predevelopment hydroperiod (Mike Hancock, Southwest Florida Water Management District, unpub. data, 2009). In one example, the natural connection between two adjacent wetlands has been restricted by a land berm that surrounds the northern half of one wetland, limiting surface-water inflow (fig. 4C). 
$\boldsymbol{A}$

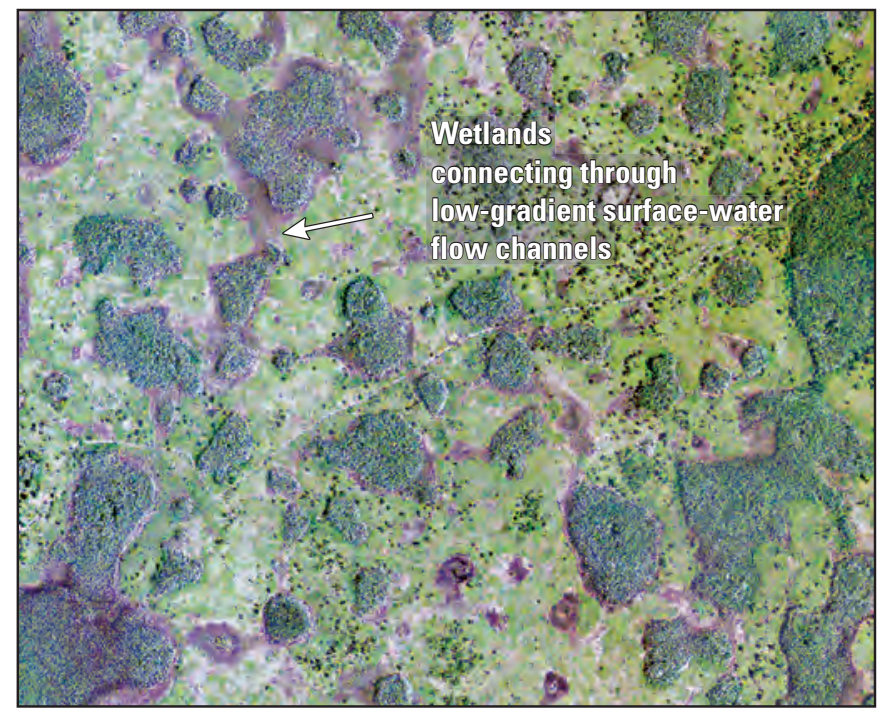

C

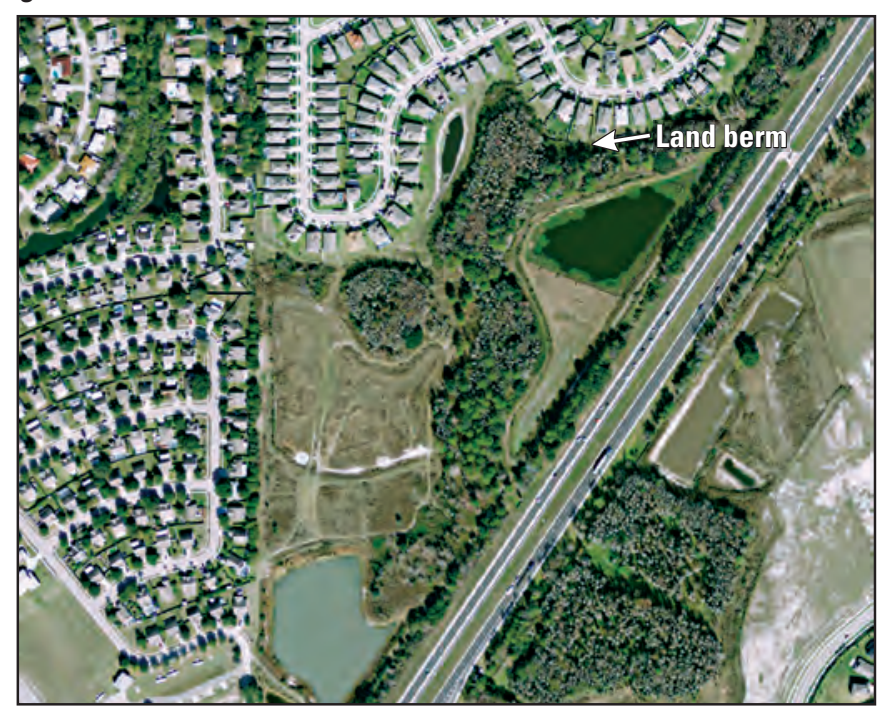

B

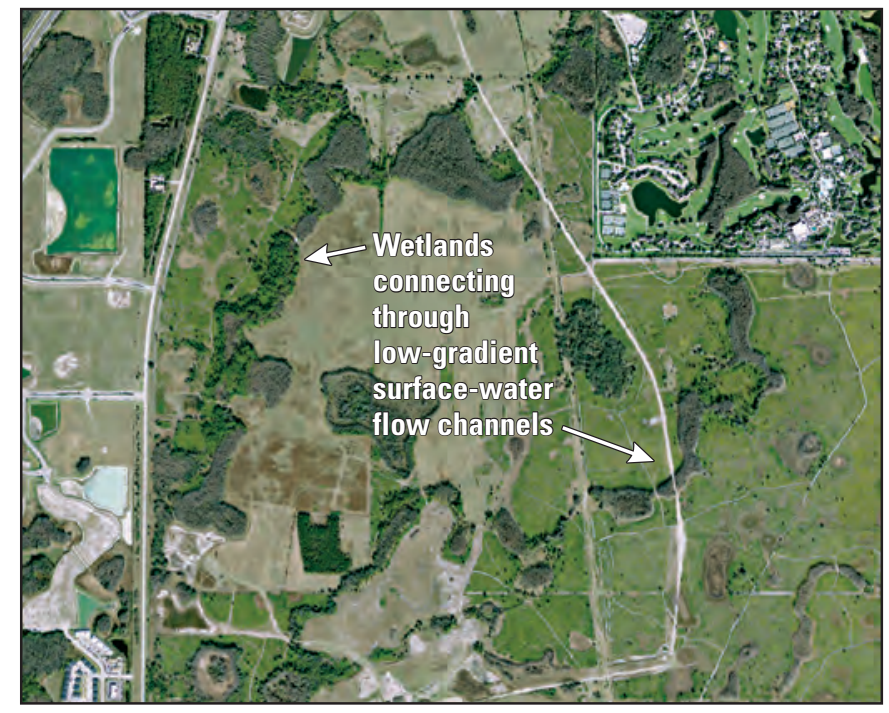

D

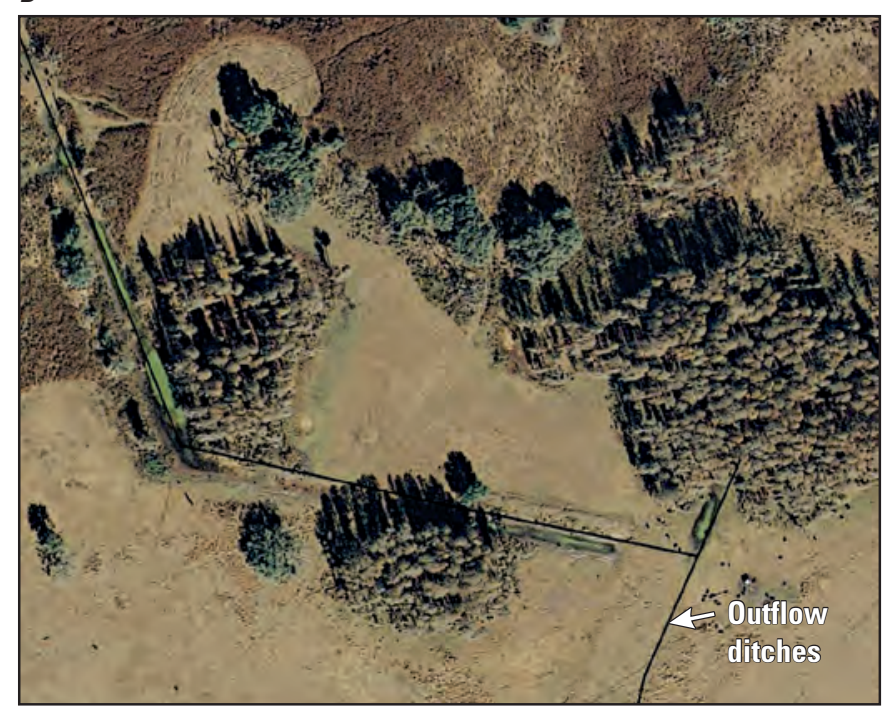

Aerial photos courtesy of the Southwest Florida Water Management District, 2009

Figure 4. $A-C$, isolated wetlands connecting through low-gradient surface-water drainage channels and $D$, outflow ditches from wetlands.

Changes in land use, such as road construction, also have affected wetland hydrology for hundreds of years (Biebighauser, 2007). Many roads in Florida were originally built through wetlands and their construction required wetland drainage, reducing the predevelopment flooded area (fig. 4C). Haag and others (2005) reported that a small roadway through the eastern part of the 8.8-acre W-05 Cypress wetland in the Cypress Creek well field (fig. 1) reduced the potential flooded area by 18 percent. A ditch created along the western side of the roadway reduced the outflow elevation below that of the wetland perimeter, artificially reducing the flooded area of the wetland at high levels. This was confirmed by stage-volume relation curves of W-05 Cypress wetland, which indicated that the maximum inundated area of the wetland was only 7.2 acres. Therefore, the inundated area of W-05 Cypress never covered the entire 8.8 -acre extent of the wetland. Although W-05 Cypress has been affected by the roadway and ditch construction, lowered groundwater levels from localized groundwater withdrawals and karst subsidence also impacted the wetland. As of 2009, this wetland was augmented with groundwater to maintain surface-water levels.

Although ditching has been beneficial to agricultural needs, associated declines in the hydrology of wetlands have been documented. Ditches are often constructed in agricultural areas to reduce the amount of standing water and 
enhance productivity (fig. 4D). A study by Bailey (1994) in the Cone Ranch (fig. 1) showed that wetland ditching eliminated some wet prairie wetlands and reduced the hydroperiod of other isolated cypress wetlands. The study determined that 49 percent of the wetlands originally present at Cone Ranch had been converted to uplands. The elevations of nearby creeks were lowered by artificial excavation, and wetlands connected to these creeks by ditches had undergone induced surface-water drainage. The percentage of individual wetland loss at the ranch was directly related to ditch size and distance from the ditch (Bailey, 1994).

Increased groundwater withdrawals have contributed substantially to the hydrologic decline of some impacted wetlands in the study area. In 2005, Florida ranked sixth in the Nation in groundwater use (Marella, 2009), and in the Northern Tampa Bay area, the majority of the groundwater is obtained from the Upper Floridan aquifer. Groundwater is obtained for a variety of uses, including agriculture, industry, and recreation, with public supply accounting for the largest use (Metz and others, 2007). The largest groundwater withdrawals are from the 11 interconnected well fields located throughout the study area (fig. 1). Average annual groundwater withdrawals from the consolidated well fields have increased steadily since the 1930 s to an average of $165 \mathrm{Mgal} / \mathrm{d}$ by the early 2000s (fig. $5 \mathrm{~A}$; Robert Peterson, Southwest Florida Water Management District, unpub. data, 2009).

Prior to 1999, Tampa Bay Water (previously known as West Coast Regional Water Supply Authority), obtained the public water supply exclusively from groundwater in the Northern Tampa Bay area (fig. 5B; Tampa Bay Water, 2010b). As efforts have been made to reduce the reliance on groundwater, alternative sources such as surface water and desalinated water have been used to supplement this use (fig. 5B; Tampa Bay Water, 2010b). Reductions in groundwater withdrawals were initiated in late 2002 at various well fields, and withdrawals decreased from an average annual rate of about $150 \mathrm{Mgal} / \mathrm{d}$ in 2001 to $96 \mathrm{Mgal} / \mathrm{d}$ during 2003-09 (Robert Peterson, Southwest Florida Water Management District, unpub. data, 2009). In 2008, Tampa Bay Water's potable water supply consisted of 61 percent groundwater, 28 percent surface water, and 11 percent desalinated water (fig. 5B; Tampa Bay Water, 2010b). Future (2012) water plans for the study area include increasing the use of surface water to 45.5 percent to augment water supplies, thereby reducing the dependency on groundwater by about 16 percent and desalinated water by 2 percent (fig. $5 B$; Tampa Bay Water, 2010b). The remainder of this report will examine current and long-term monitoring data at three well fields (Starkey, Cypress Creek, and Cypress Bridge) to determine the factors that influence the recovery of wetlands impacted by historical groundwater withdrawals.

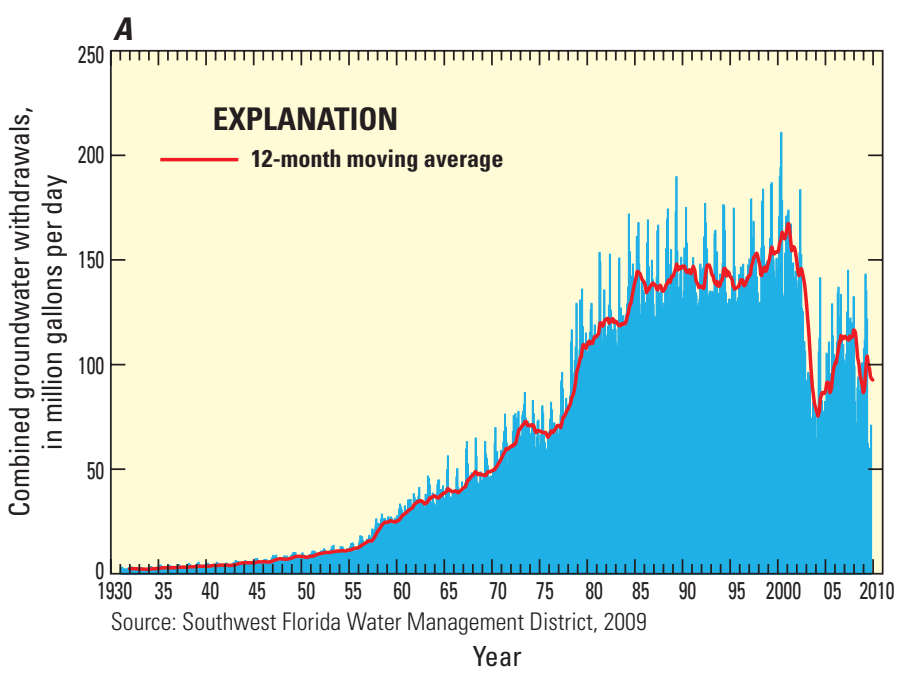

B

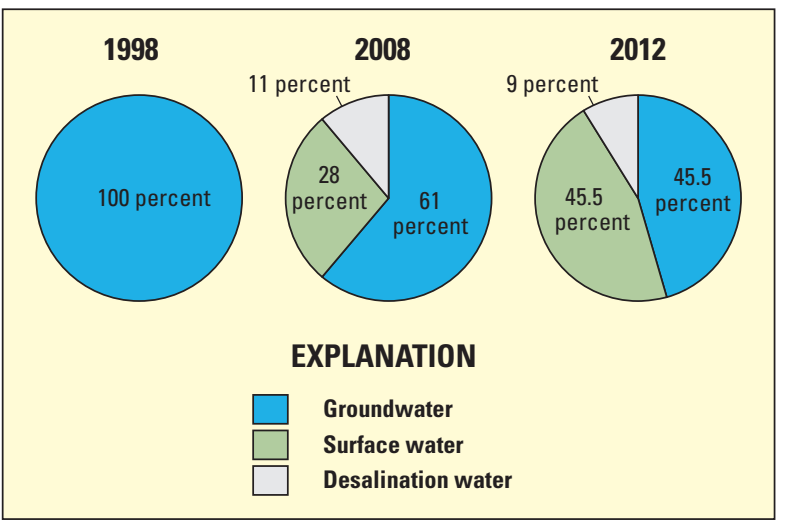

Source: Tampa Bay Water, 2010

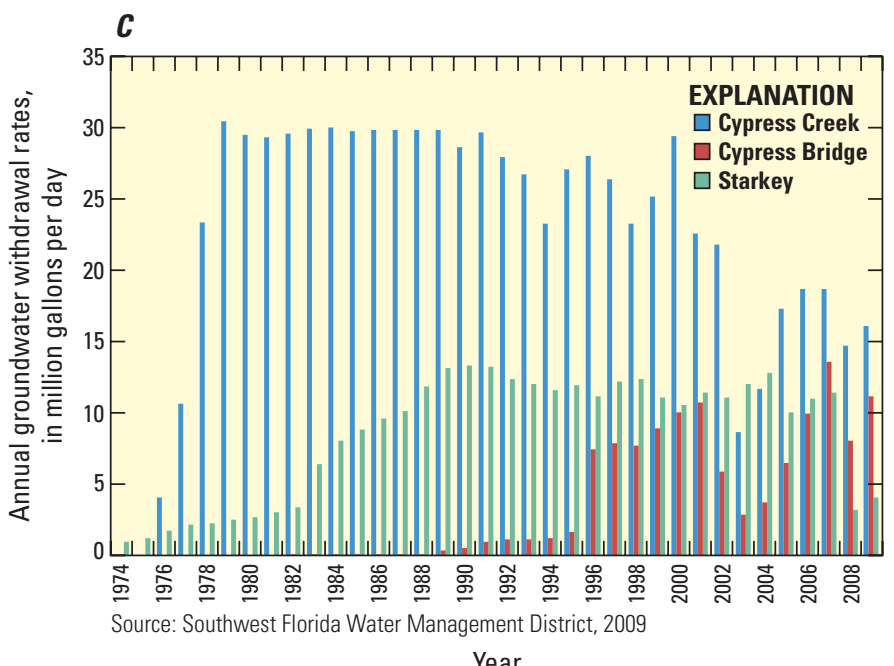

Figure 5. $\quad A$, Combined groundwater withdrawals from the 11 consolidated well fields; $B$, allocation for water supply in the Northern Tampa Bay area; and $C$, annual groundwater withdrawal rates for the Starkey, Cypress Creek, and Cypress Bridge well fields. 


\section{Description of Well Fields}

Wetlands selected for this study are located at three well fields (Starkey, Cypress Creek, and Cypress Bridge) in the Northern Tampa Bay area (fig. 1). The annual groundwater withdrawal rates for these well fields are shown in figure $5 C$. Starkey well field is located about 7 miles (mi) east of the Gulf of Mexico on a flat coastal flood plain situated in a hummocky karst environment (Hutchinson, 1984). Starkey well field covers about $12 \mathrm{mi}^{2}$ of undeveloped land that mostly consists of pine flatwoods and sand hills; about a third of the area consists of cypress domes, marshes, and wet prairies (Rochow, 1998). Large strands of riverine swamps (associated with the Pithlachascotee and Anclote Rivers) are located to the north, south, and east of the well field. Lands adjacent to the well field are mostly rural, although moderate-density residential development borders the western side of the property and a four-lane highway borders the eastern side.

In the Starkey well field, 14 production wells pump groundwater from the Upper Floridan aquifer, and these wells are located along an approximate 5-mi east-west orientation (fig. 6A). Between 1975 and 1983, annual pumpage ranged from about 1 to $6 \mathrm{Mgal} / \mathrm{d}$, and from 1984 to 2007, annual pumpage ranged from 8 to $13 \mathrm{Mgal} / \mathrm{d}$. Groundwater withdrawals were then reduced to less than $4 \mathrm{Mgal} / \mathrm{d}$ during 2008 (fig. 5C).

Groundwater withdrawals began in the mid-1970s from four production wells on the western part of Starkey well field, and by the late 1970s, hydrologic and vegetation changes were noted in these areas (Rochow and others, 1976; Rochow and Bartos, 1978). The first observations of environmental declines affecting Starkey well-field wetlands included reduced hydroperiods followed by stresses to the aquatic vegetation (Rochow 1982, 1983a, 1985a, 1998). Later impacts to the wetlands included replacement of aquatic plants by upland plants or trees, introduction of invasive species, wetland-bottom subsidence, soil loss and compaction, leaning and fallen trees, intense fires, and a reduction in wetland-dependent wildlife (Dooris and others, 1990; Rochow, 1998). By 1983, groundwater withdrawals were concentrated at the center of the well field, and in following years, similar adverse effects were noted in this area (Rochow, 1998). In 1989, groundwater production began at two wells in the eastern part of the well field, but at a smaller rate $(2.7 \mathrm{Mgal} / \mathrm{d})$. Consequently, wetlands in this area were not as impacted as those in the central and western parts of the well field (Rochow, 1998).

Because of the adverse effects of groundwater withdrawals on the hydrology of wetlands at Starkey well field, various water-management measures were implemented to minimize the impacts to wetlands and reduce the reliance on groundwater. Since 1990, one impaired wetland at Starkey well field has been augmented with groundwater to raise water levels and protect native flora and fauna (Tampa Bay Water, 2000). In 1998, Tampa Bay Water implemented the
Optimized Regional Operations Plan to rotate and optimize production between the 11 well fields (Tampa Bay Water, 2004, 2010b). In 2008, groundwater withdrawals at Starkey well field were reduced to an average annual rate of about $4 \mathrm{Mgal} / \mathrm{d}$, a reduction of more than half the 2007 rate of $11 \mathrm{Mgal} / \mathrm{d}$ (Robert Peterson, Southwest Florida Water Management District, unpub. data, 2009).

Cypress Creek well field is about $7 \mathrm{mi}^{2}$, and is located about 8 mi east of Starkey well field (fig. 1). Most of the well field lies within a natural, relatively undisturbed setting surrounded by agricultural and residential areas. About 62 percent of the well field is composed of palustrine wetlands that are bisected by Cypress Creek, which flows southward through the center of the well field (fig. 7A). The creek is poorly defined where it meanders through the Big Cypress Swamp (figs. 1 and 7A). In the low-lying areas, the water table is at or above land surface part of the year, and in the upland areas the water table gently slopes toward Cypress Creek (Yobbi, 2002).

A total of 12 Upper Floridan aquifer production wells are located at Cypress Creek well field trending along an approximate 2.5 -mi northeast to southwest orientation (fig. 7A). Groundwater withdrawals expanded from three wells in mid-1976 to 13 wells by 1980 . The average annual production rate from 1978 to 2002 was approximately $28 \mathrm{Mgal} / \mathrm{d}$ (fig. 5C). Groundwater withdrawals were reduced to an average of $15 \mathrm{Mgal} / \mathrm{d}$ after 2002 to lessen the impacts to wetlands at this well field (fig. 5C).

As with Starkey well field, large declines in surficial and Upper Floridan aquifer water levels negatively affected wetlands at Cypress Creek well field after the production rate increased (Rochow, 1998). These impacts included reduced hydroperiods, stresses to aquatic vegetation, replacement of aquatic plants by upland plants, wetland-bottom subsidence, development of sinkholes, leaning and fallen trees, intense fires, soil loss and compaction, and the reduction in wetlanddependant wildlife (Rochow and Bradbury, 1978; Rochow 1981, 1983b, 1983c; Mike Hancock, Southwest Florida Water Management District, unpub. data, 2009). Because of declines in aquifer water levels and the resulting reduced hydroperiods, five wetlands in the Cypress Creek well field have been augmented with groundwater to protect native flora and fauna (Tampa Bay Water, 2004).

Cypress Bridge is a dispersed well field located several miles south of Cypress Creek well field, and encompasses about 73 acres of proximate but unconnected publicly and privately owned land parcels in Pasco and northern Hillsborough Counties (fig. 1). The 10 production wells are interspersed among marshes, cypress domes, wet prairies, and residential and commercial areas; in recent years residential and commercial development have increased (fig. 8A). About 32 percent of Cypress Bridge well field is composed of palustrine wetlands that include mixedhardwood and cypress swamp forests associated with several small creeks in the area. 
A.
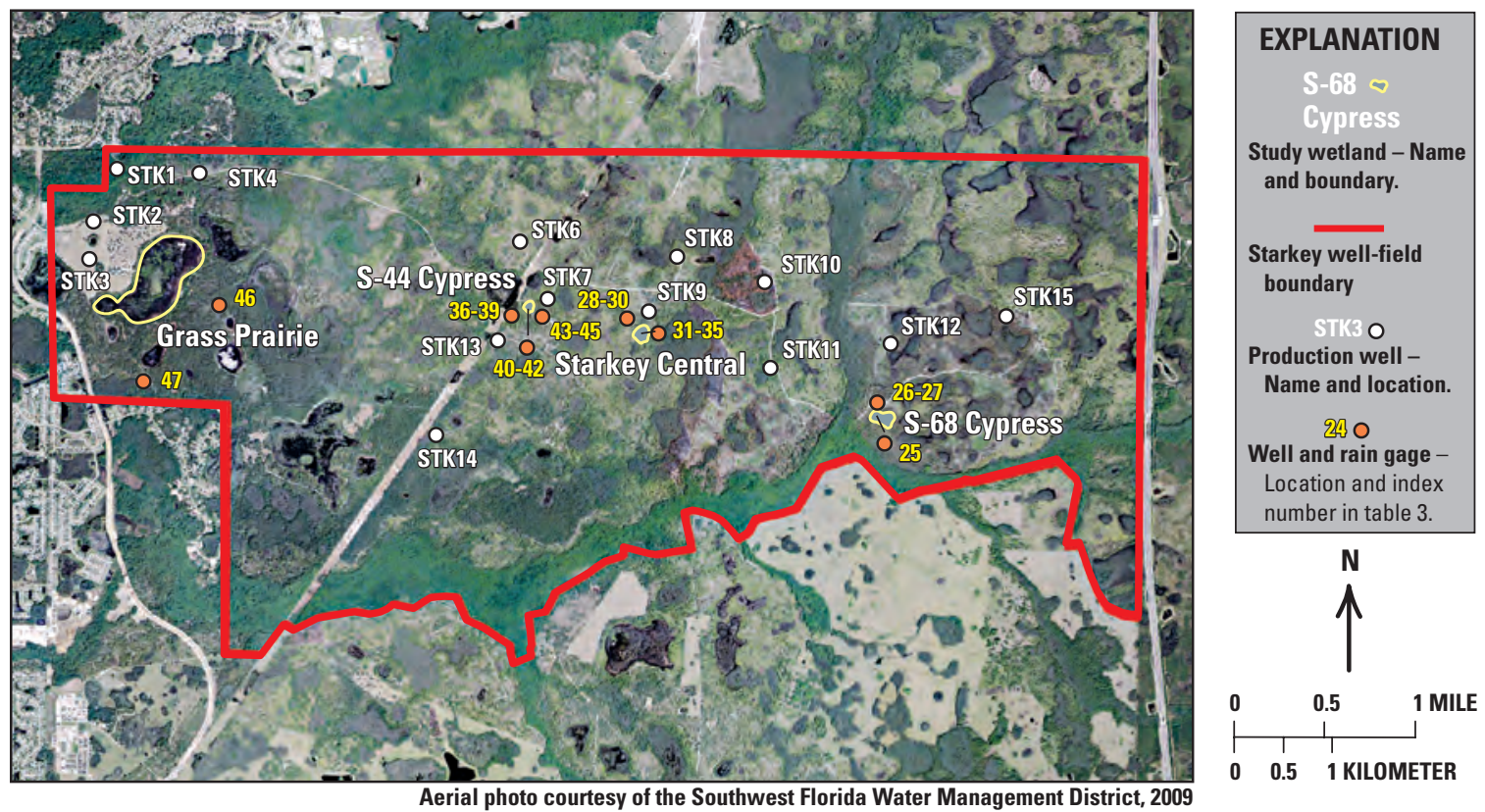

B. S-68 Cypress, December, 2009

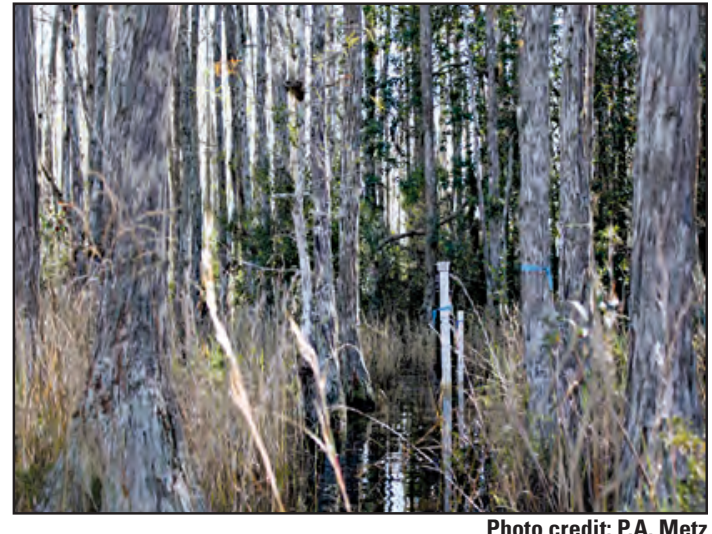

D. S-44 Cypress, November, 2007

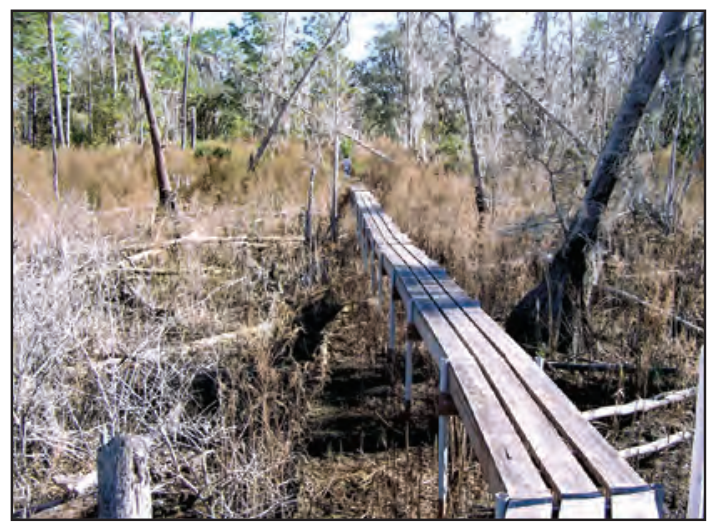

Photo credit: P.A. Metz
C. Starkey Central, November, 2007

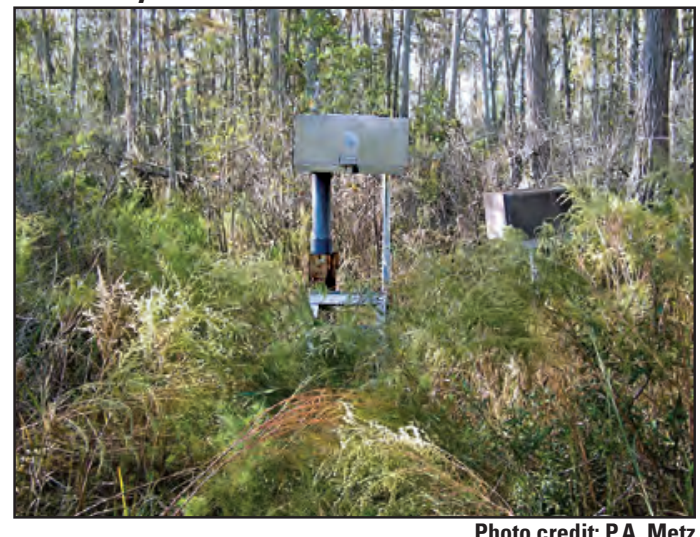

E. Grass Prairie, January, 2009

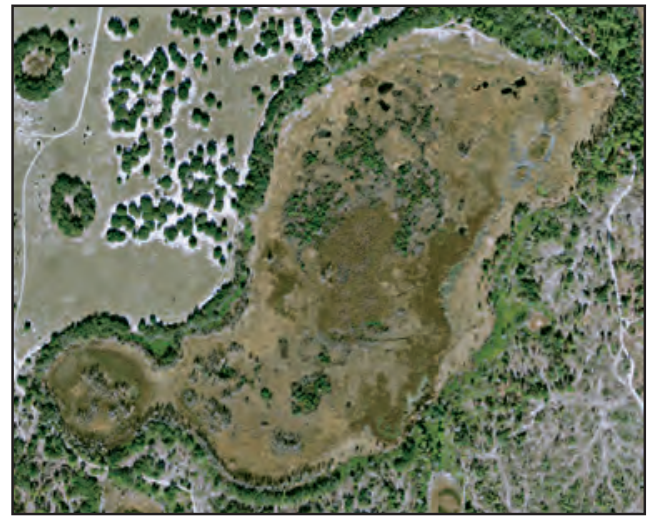

Aerial photo courtesy of the Southwest Florida Water Management District, 2009

Figure 6. A, location of the study wetlands and production wells at the Starkey well field and $B$ - $E$, individual study wetlands. 

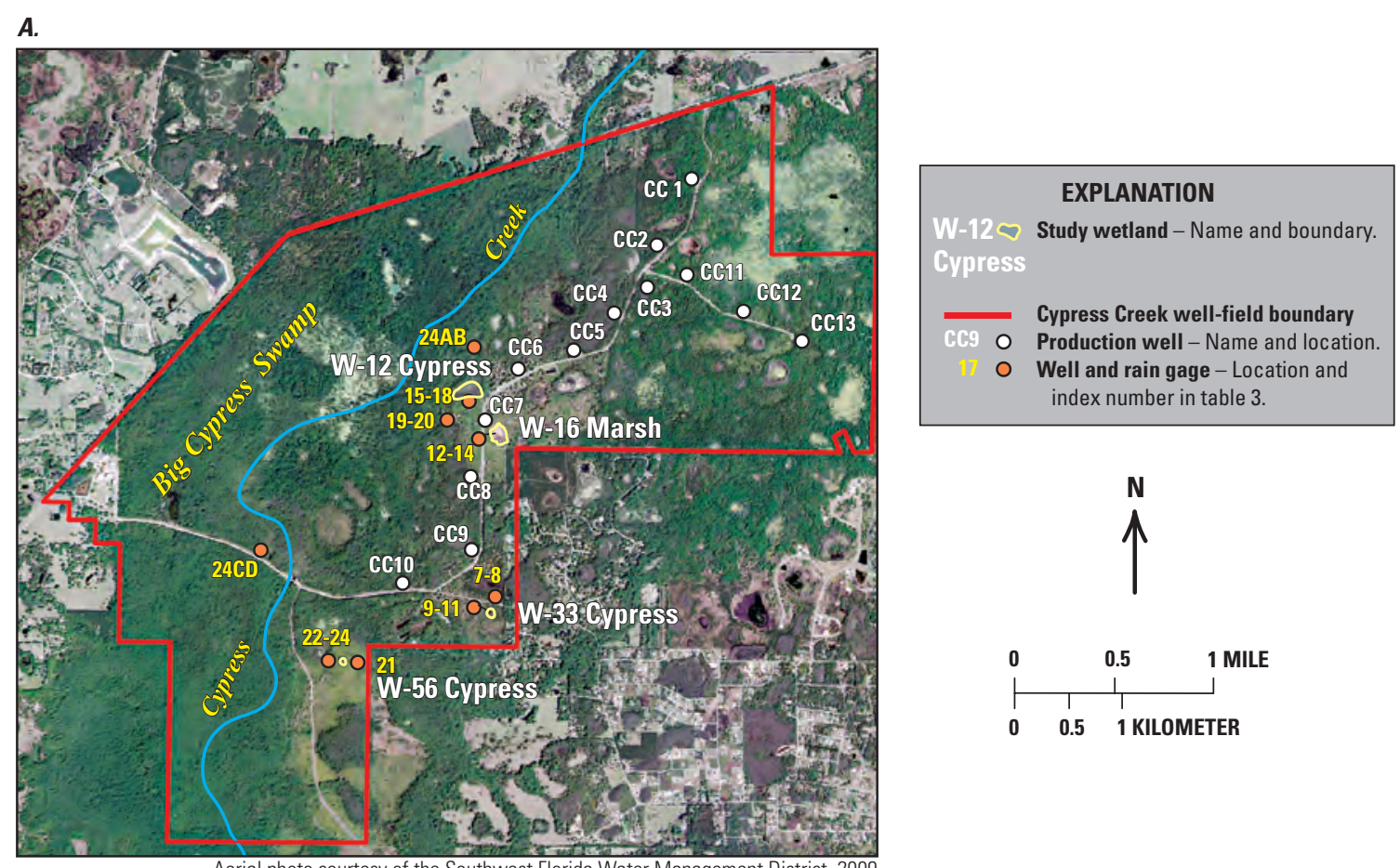

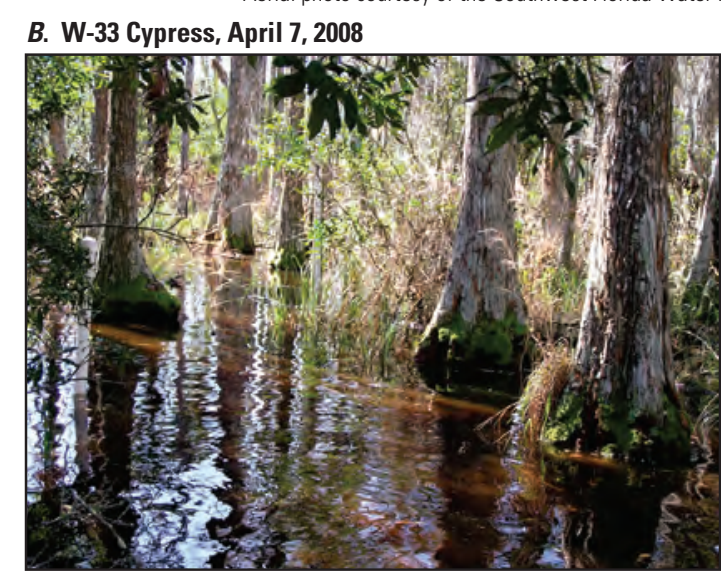

D. W-12 Cypress, April 7, 2008

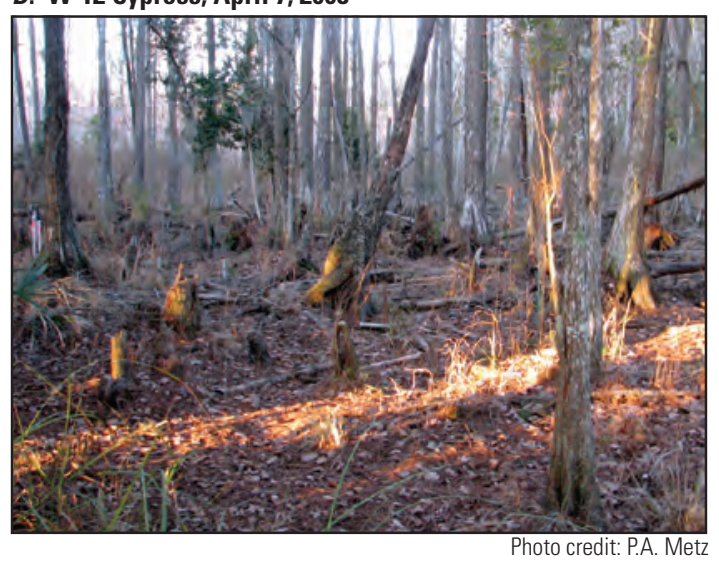

C. W-56 Cypress, April 7, 2008

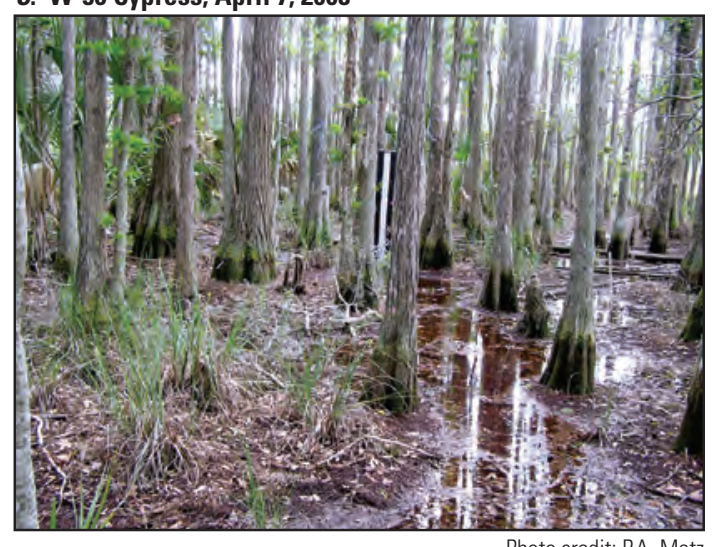

E. W-16 Marsh, April 7, 2008

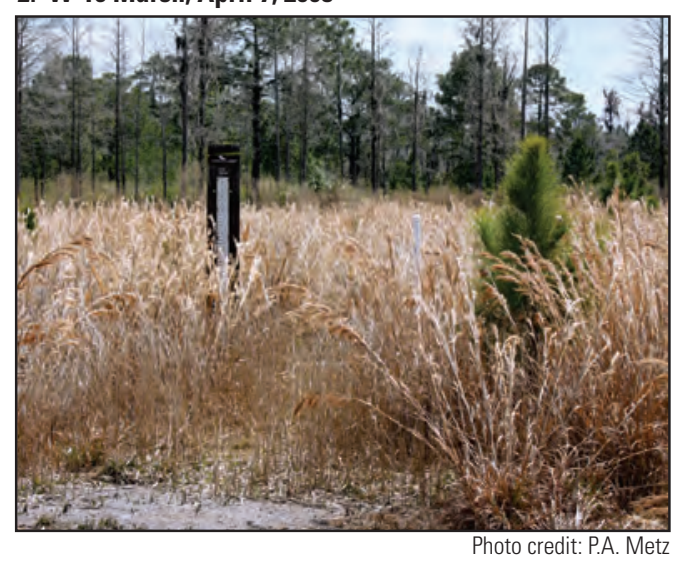

Figure 7. A, location of the study wetlands and production wells at the Cypress Creek well field and $B$ - $E$, individual study wetlands. 
A

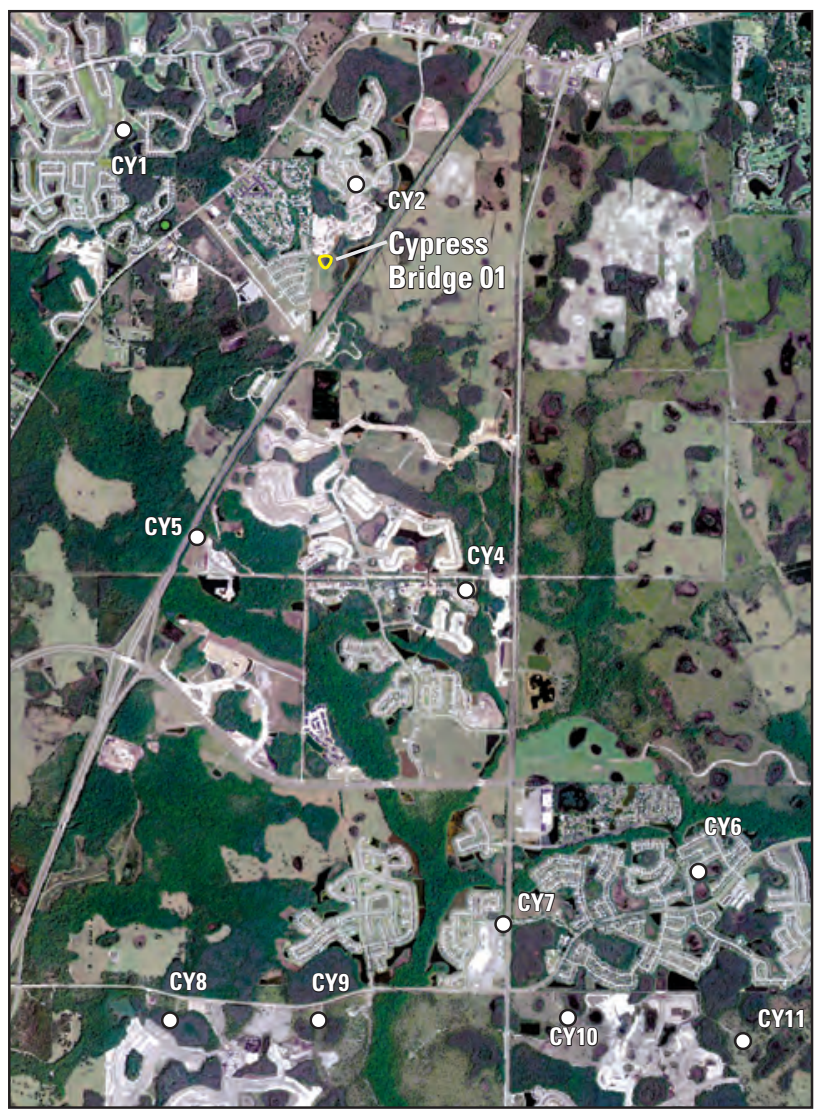

Aerial photo courtesy of the Southwest Florida Water Management District, 2009
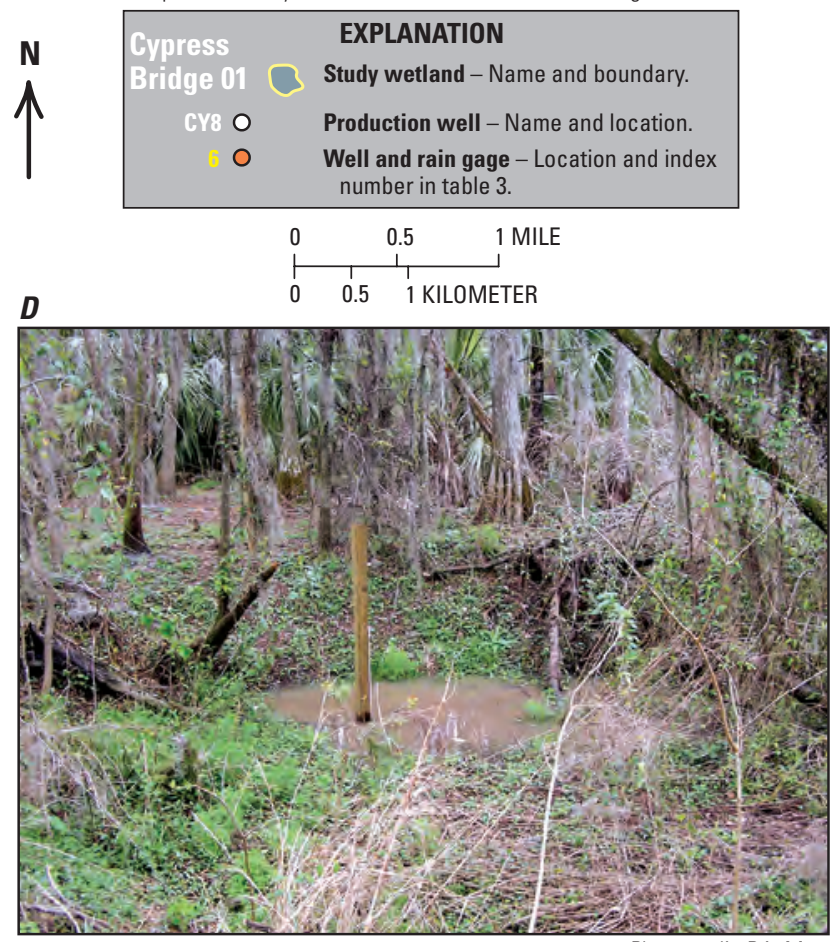

Photo credit: P.A. Metz

\section{B}

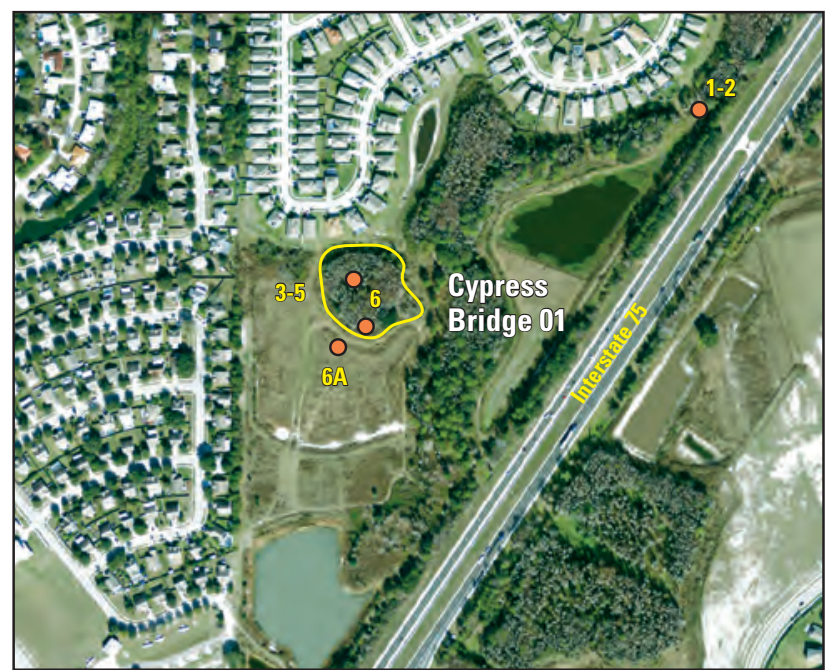

Aerial photo courtesy of the Southwest Florida Water Management District, 2009

C

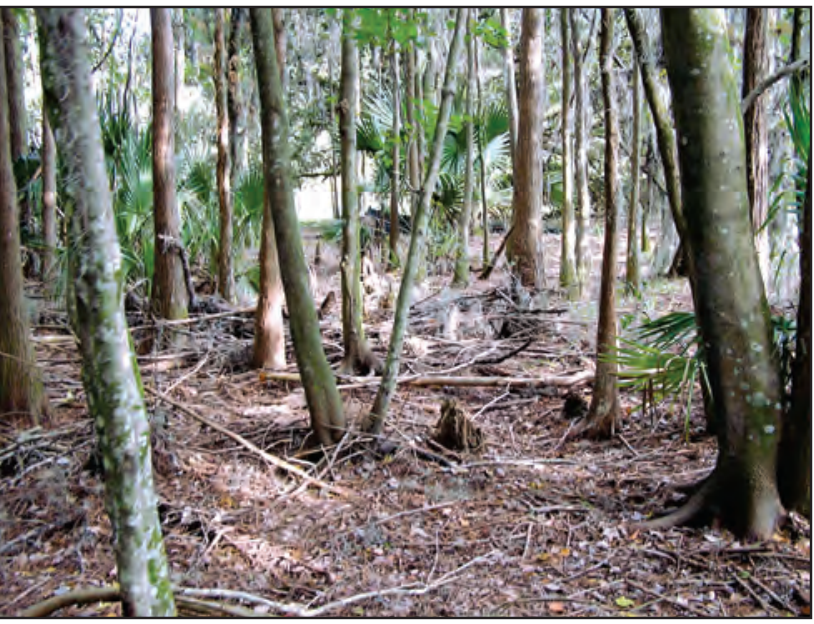

Photo credit: P.A. Metz

\section{$E$}

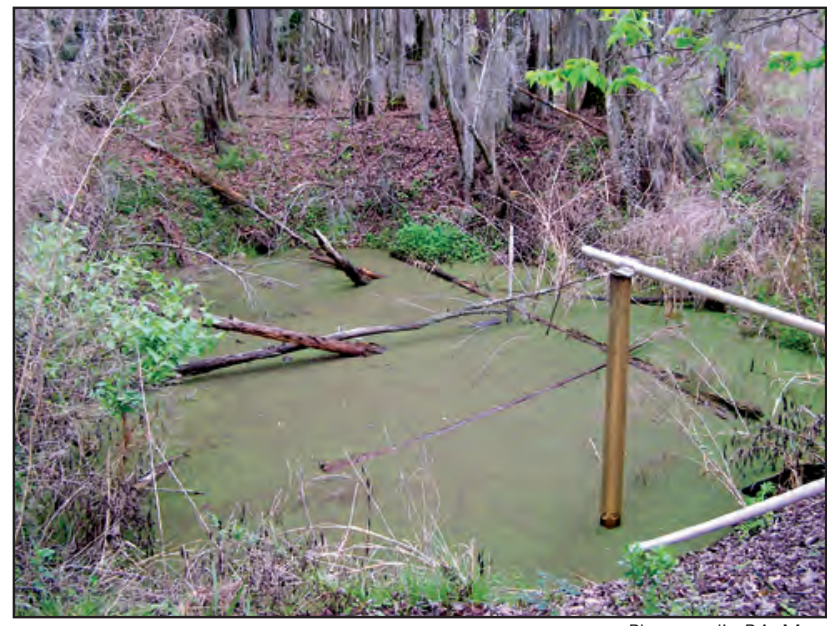

Photo credit: P.A. Met

Figure 8. A, location of the study wetland and production wells at the Cypress Bridge well field; $B$, monitoring sites and land-use development surrounding the wetland; $C$, encroachment of upland species and tree fall; and $D-E$, small and large sinkholes at the Cypress Bridge 01 wetland. 
Unlike groundwater withdrawals at the Starkey and Cypress Creek well fields, withdrawals have increased at Cypress Bridge well field. The annual average withdrawal rate at Cypress Bridge well field was less than $0.5 \mathrm{Mgal} / \mathrm{d}$ from 1982 to 1995. Production increased to an annual average withdrawal rate of approximately $8 \mathrm{Mgal} / \mathrm{d}$ from 1996 to 2009 (fig. 5C).

\section{Study Design}

To determine the factors that influence the hydrologic recovery of wetlands in the Northern Tampa Bay area, nine wetlands in various stages of hydrologic impairment were examined. Established minimum surface-water levels for wetlands set by the Southwest Florida Water Management District $(1999 a, b)$ were used to help determine the degree of wetland impairment (Southwest Florida Water Management District, 1999c). For wetlands that did not have an established minimum surface-water level, the classification was based on comparisons with control wetlands from a study by Lee and others (2009), and with nearby wetlands that had achieved minimum surface-water levels. In addition, historical (1975-98) and recent (2005-07) ecological monitoring data collected by the Wetland Assessment Procedure (WAP) were used to help determine the hydrologic impairment resulting from groundwater withdrawals (Southwest Florida Water Management District, 2005; Southwest Florida Water Management District 2008; Mike Hancock, Southwest Florida Water Management District, unpub. data, 2009). The study wetlands were then classified as unimpacted, minimally impacted, moderately impacted, or severely impacted.

In the present study, the wetland classified as unimpacted generally had similar historical flooded-area duration characteristics to natural wetlands in west-central Florida (Lee and others, 2009). Vegetation surveys of the unimpacted wetland reported native indicator species adapted for growing in standing water or saturated soils (Hancock and others, 2005; Mike Hancock, Southwest Florida Water Management District, unpub. data, 2009).

Minimally impacted wetlands had hydroperiods influenced by groundwater withdrawals or above-average rainfall conditions. These wetlands had a slightly above average decline in wetland water levels during average rainfall years and had some vegetation changes. Vegetation surveys indicated stresses to the tree canopy and a reduction in vegetative groundcover (Hancock and others, 2005; Mike Hancock, Southwest Florida Water Management District, unpub. data, 2009).

Moderately impacted wetlands had a more reduced wetland hydroperiod than minimally impacted wetlands under the same climatic conditions. Historical flooded-area duration characteristics for moderately impacted wetlands were similar to those of impacted wetlands in west-central Florida as described by Lee and others (2009). Documented impacts include soil loss by desiccation and compaction, vegetation changes, or changes in surface-water inflow and outflow patterns (Mike Hancock, Southwest Florida Water Management District, unpub. data, 2009). Field observations revealed that the moderately impacted wetlands were influenced by karst subsidence or sinkhole development. Vegetation surveys indicated leaning trees, introduction of non-native species, and encroachment of upland species within the deepest areas of the wetlands.

Severely impacted wetlands generally had little to no standing water during the study period or in prior years. Impacts to the wetlands included loss of wetland soil sediments by desiccation and compaction, loss of sediment due to intense fires, or both. Karst subsidence features were observed at these wetlands. Vegetation surveys indicated extensive tree loss, leaning and fallen trees, and encroachment of upland species within the deepest areas of the wetlands (Hancock and others, 2005; Mike Hancock, Southwest Florida Water Management District, unpub. data, 2009).

\section{Study Wetlands}

The study wetlands located in the Starkey well field consist of three isolated cypress domes (S-68 Cypress, Starkey Central, and S-44 Cypress) and one isolated marsh (Grass Prairie) (fig. 6A and table 1). S-68 Cypress wetland is a 5.8-acre cypress dome in the southeastern part of the well field, and is classified as unimpacted (fig. $6 B$ and table 1). Long-term hydrologic monitoring data (1989-2009) at S-68 Cypress indicate the wetland has not experienced a reduced hydroperiod and has similar hydroperiods to wetlands located in a natural setting (Lee and others, 2009). Data collected through the WAP indicate that this wetland is in good health, with all trees, shrubs, and groundcover located in appropriate zones within the wetland boundary (Hancock and others, 2005; Mike Hancock, Southwest Florida Water Management District, unpub. data, 2009).

Starkey Central is a 2.8-acre cypress dome located in the center of Starkey well field, and is classified as moderately impacted (fig. $6 \mathrm{C}$ and table 1). Hydrologic and biological monitoring began in 1985, 2 years after pumping was shifted to the center of the well field. Wetland data collected at this time indicated the cypress dome was still in good health. Within 4 to 5 years after monitoring began, however, observations indicated a reduced hydroperiod, influx of transitional and upland species, moderate soil subsidence around tree roots, land surface subsidence, and increased mortality and leaning of cypress trees (Rochow, 1998; Mike Hancock, Southwest Florida Water Management District, unpub. data, 2009). In addition, an intense fire in the 1990s compounded the deterioration of ecological conditions in the cypress dome.

$\mathrm{S}-44$ Cypress is a 2.5-acre cypress dome in the center of Starkey well field, and is classified as severely impacted (fig. $6 D$ and table 1). Hydrologic and biological monitoring, which began at this site in 1988, documented a reduced 
Table 1. Name, location, and other characteristics of the study wetlands.

[IC, isolated cypress; $\mathrm{M}$, marsh; latitude and longitude in degrees $\left({ }^{\circ}\right)$, minutes $(')$, and seconds $\left.\left({ }^{\prime \prime}\right)\right]$

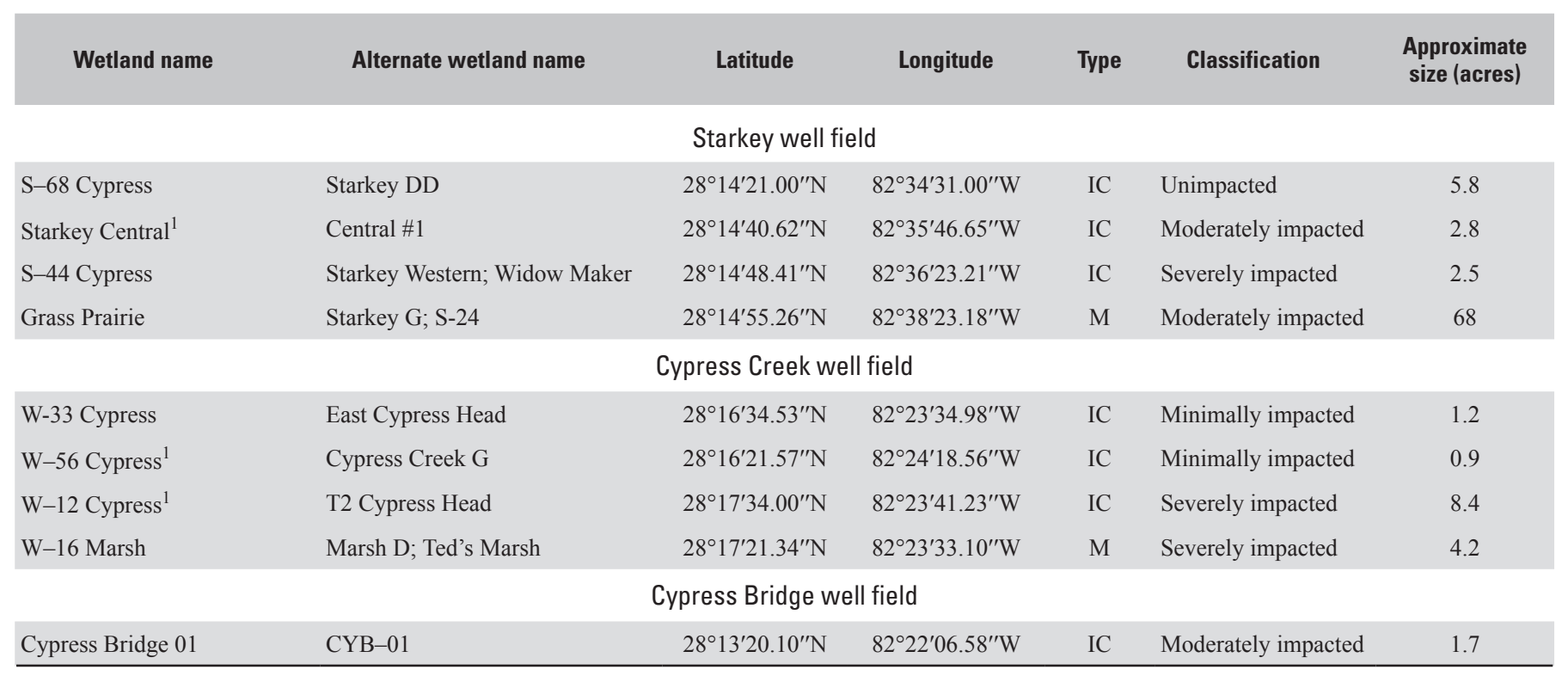

${ }^{1}$ Surface-water minimum levels established by Southwest Florida Water Management District, 1999.

hydroperiod, fire scars on most of the cypress trees, soil subsidence due partly to burning of the wetland-bottom sediments, and many leaning and fallen trees (Rochow, 1998). In 1990, the central part of the wetland subsided several feet due to a subsurface limestone collapse (Stewart and Stedje, 1990; Watson and others, 1990), and the number of fallen trees increased during subsequent years. Aerial photographic surveys of the wetland conducted from 1952 to 1989 indicate that the wetland canopy was healthy through 1981, but had deteriorated by 1989 (Rochow and Rhinesmith, 1991). Currently (2009), most of the cypress trees in S-44 Cypress have fallen (fig. 6D).

Grass Prairie is a 68-acre marsh in the western part of Starkey well field, and is classified as a moderately impacted (fig. $6 E$ and table 1). Long-term monitoring indicates the wetland has a reduced hydroperiod, a reduction in native aquatic vegetation, and has undergone extensive soil subsidence (Rochow, 1998; Hancock and others, 2005; Mike Hancock, Southwest Florida Water Management District, unpub. data, 2009). The reduced hydroperiod has created cracks and fissures in the wetland-bottom sediments, and soil subsidence has caused large clumps of soil to detach from the wetland bottom. Sediment loss was estimated to be 1 to $2 \mathrm{ft}$ in thickness and to cover an area of $30 \times 200 \mathrm{ft}$ (Rochow, 1998).

The study wetlands located in the Cypress Creek well field consist of three isolated cypress domes (W-33 Cypress, $\mathrm{W}-56$ Cypress, and $\mathrm{W}-12$ Cypress) and one isolated marsh (W-16 Marsh) (fig. 7A and table 1). W-33 Cypress is a 1.2-acre cypress dome in the southern part of Cypress Creek well field, and is classified as minimally impacted (fig. 7B). In 1980, initial observations of this wetland indicated no noticeable adverse impacts to wetland health. By 1984, however, vegetative stresses to the wetland canopy were evident, and in 1999, a fire damaged the wetland and adjacent forested area (Rochow, 1998). Long-term water-level records (1989-2009) do not indicate a reduced wetland hydroperiod, although some encroachment of upland species has occurred (Hancock and others, 2005; Mike Hancock, Southwest Florida Water Management District, unpub. data, 2009).

$\mathrm{W}-56$ Cypress is an 0.9-acre cypress dome in the southern part of Cypress Creek well field, and is classified as minimally impacted (fig. $7 C$ and table 1). W-56 Cypress is located about $1 \mathrm{mi}$ from the high-production area of the well field, and although observations since 1980 indicate a below average hydroperiod during drought periods, they also indicate that wetland water levels recover during average rainfall periods (Rochow, 1985b; 1998; Mike Hancock, Southwest Florida Water Management District, unpub. data, 2009). Long-term vegetation monitoring indicates that the wetland has remained healthy, although some encroachment of transitional tree and groundcover species has occurred (Hancock and others, 2005; Mike Hancock, Southwest Florida Water Management District, unpub. data, 2009).

W-12 Cypress is an 8.4-acre cypress wetland in the center of Cypress Creek well field, and is classified as severely impacted (fig. 7D and table 1); groundwater withdrawals are more concentrated in this part of the well field than at W-33 Cypress and W-56 Cypress. Based on longterm monitoring, W-12 Cypress has experienced a reduction in hydroperiod, encroachment of upland species, soil subsidence, tree root exposure, wetland-bottom subsidence, and canopy thinning due to abnormally high tree fall (Hancock and others, 2005; Mike Hancock, Southwest Florida Water 
Management District, unpub. data, 2009). During 16 of the past 30 years, the wetland has been completely dry. Water was present in this wetland during above-average rainfall periods during 1981-83, 1997-98, and 2002-05 (Mike Hancock, Southwest Florida Water Management District, unpub. data, 2009).

$\mathrm{W}-16$ Marsh is a 4.2 -acre wetland, and is the most severely impacted of the study wetlands (fig. $7 E$ and table 1). Similar to W-12 Cypress, this marsh is located in the center of Cypress Creek well field where groundwater withdrawals are concentrated (fig. 7A). Prior to the first groundwater withdrawals in 1975, W-16 Marsh contained standing water in the center of the wetland for 8 to 10 months of the year and contained native aquatic species (Rochow, 1998). Within the first several years of well field production, however, the marsh drained completely, and standing water was present at this site for only brief periods during large rainfall events (Rochow and Bradbury, 1978; Rochow, 1998; Mike Hancock, Southwest Florida Water Management District, unpub. data, 2009). In 1983, five sinkholes were reported near the perimeter of the wetland (Rochow, 1983c). Other observed effects at W-16 Marsh include oxidation of wetland soil, several intense fires, a decrease in native aquatic vegetation, and encroachment of upland species (Pinus elliotti; slash pine).

Cypress Bridge 01 is a 1.7-acre cypress dome in the northern part of Cypress Bridge well field (figs. 1 and $8 A$ ) and is classified as moderately impacted (table 1 ). The wetland is located directly south of a high-density housing development (fig. $8 \mathrm{~B}$ ) and wetland mitigation ponds are present to the south and east. A small ditch that borders the western side of Cypress Bridge 01 channels water into the wetland during high rainfall events. Production well CY2 is 0.43 -mi northeast of the wetland, and several sinkholes formed along the wetland bottom during well development in 1996 (Mike Hancock, Southwest Florida Water Management District, unpub. data, 2009; fig. $8 D-E$ ). In addition to the sinkholes, interruptions in surface-water flow patterns from connecting wetlands have resulted from residential and highway development. Because of these changes, the wetland has experienced a reduced hydroperiod, excessive tree fall, introduction of upland species, and a decrease in tree canopy (Hancock and others, 2005; Mike Hancock, Southwest Florida Water Management District, unpub. data, 2009; fig. 8C).

\section{Methods of Investigation}

The study wetlands were examined based on four factors known to influence the hydrologic condition and recovery of wetlands in west-central Florida including the topographic setting, permeability of the underlying sediments, recent karst activity, and depth to the potentiometric surface of the Upper Floridan aquifer beneath the wetland. Multiple lines of evidence were used to establish how each of these four factors has affected the ability of water levels in the study wetlands to recover. Depending on the availability of data, comparisons were made between all or subsets of the nine study wetlands. Table 2 lists each factor, supporting evidence for that factor, and which of the study wetlands had data that could be used to describe the effect.

The topographic settings of the study wetlands were analyzed using surface-elevation data collected by LIDAR (Light Detection and Ranging) - a remote sensing system used to collect topographic data (Fugro Earthdata, Inc., 2010). The surface-elevation data were used to determine the physical setting of the study wetlands and its relation to other topographical features such as upland areas, rivers, or low-lying discharge areas. The LIDAR data, satellite imagery, and aerial photography also were used to determine depressional inflow and outflow connections between isolated wetlands.

The underlying geology at or near the study wetlands was interpreted from existing geologic and borehole geophysical logs, geologic contour maps, grain-size analysis, and descriptions of cuttings from USGS wells drilled during the study. To compare and contrast the underlying geology and wetland-bottom sediments between study wetlands, continuous cores were collected at six study wetlands using a vibracore (table 2). These cores were collected using a Bradford pneumatic vibrator, which drove a 3-in.-diameter aluminum core barrel into the underlying substrate material until an impenetrable substrate was encountered (Lanesky and others, 1979). This method produced a complete intact profile of the wetland-bottom sediments and a shallow profile of the underlying geology. The vibracores were split in half for visual inspection, measured, described, and photographed for archiving. At selected intervals within the vibracores, samples were collected to determine the relative mass percentages of sand, silt (organics), and clay. These samples were analyzed using grain-size analysis techniques as described by Wentworth (1929) and Shepard (1954).

To define the geometry and to detect any subtle depressional features in the wetland bottom, bathymetric data were collected at six of the study wetlands by USGS personnel (table 2). The elevation of the wetland bottom was surveyed at numerous locations across its extent using a Topcon Total Station (Topcon GTS 303D). Bathymetric maps were then created using a GIS (geographical information system) in which digital interpolation and contouring routines were used to delineate the wetland-bottom configuration. Bathymetric maps also were used to determine the size of the inundated area and the water volume stored in the wetlands over a range of historical stage values. These methods are discussed further in Haag and others (2005) and Lee and others (2009).

To provide evidence of karst subsidence in wetland basins, ground-penetrating radar (GPR) surveys were conducted at a severely impacted wetland (W-16 Marsh) and a moderately impacted wetland (Cypress Bridge 01). This surface-geophysical technique can profile subsurface layers and identify areas where deposits are slumped downward or breached by subsidence from sinkhole development (Wilson and Garmen, 2002). In both GPR surveys, data were collected only within the wetland perimeter. The surveys were 
Table 2. Methods used to describe the factors affecting the hydrologic condition and recovery of each study wetland.

\begin{tabular}{|c|c|c|c|c|c|c|c|c|c|}
\hline \multirow[b]{2}{*}{ Factors and methods } & \multicolumn{9}{|c|}{ Wetlands } \\
\hline & $\begin{array}{c}\text { S-68 } \\
\text { Cypress }\end{array}$ & $\begin{array}{l}\text { Starkey } \\
\text { Central }\end{array}$ & $\begin{array}{c}\text { S-44 } \\
\text { Cypress }\end{array}$ & $\begin{array}{l}\text { Grass } \\
\text { Prairie }\end{array}$ & $\begin{array}{l}\text { W-33 } \\
\text { Cypress }\end{array}$ & $\begin{array}{l}\text { W-56 } \\
\text { Cypress }\end{array}$ & $\begin{array}{l}\text { W-12 } \\
\text { Cypress }\end{array}$ & $\begin{array}{l}\text { W-16 } \\
\text { Marsh }\end{array}$ & $\begin{array}{l}\text { Cypress } \\
\text { Bridge } 01\end{array}$ \\
\hline \multicolumn{10}{|c|}{ Topographical setting } \\
\hline $\begin{array}{l}\text { Light detection and ranging (LIDAR) data, satellite } \\
\text { imagery, aerial photography, topographic maps }\end{array}$ & $\mathrm{x}$ & $\mathrm{x}$ & $\mathrm{x}$ & $\mathrm{x}$ & $\mathrm{x}$ & $\mathrm{x}$ & $\mathrm{x}$ & $\mathrm{x}$ & $\mathrm{x}$ \\
\hline Visual inspection of wetland-bottom sediments & $\mathrm{x}$ & $\mathrm{x}$ & $\mathrm{x}$ & $\mathrm{x}$ & $\mathrm{x}$ & $\mathrm{x}$ & $\mathrm{x}$ & $\mathrm{x}$ & $\mathrm{x}$ \\
\hline Collection and description of vibracores & $\mathrm{x}$ & & $\mathrm{x}$ & $\mathrm{x}$ & $\mathrm{x}$ & $\mathrm{x}$ & & $\mathrm{x}$ & \\
\hline Grain-size analysis of vibracore & $\mathrm{x}$ & & $\mathrm{x}$ & $\mathrm{x}$ & $\mathrm{x}$ & $\mathrm{x}$ & & $\mathrm{x}$ & \\
\hline \multicolumn{10}{|c|}{ Evidence of recent karst subsidence } \\
\hline Ground-penetrating radar survey & & & & & & & & $\mathrm{x}$ & $\mathrm{x}$ \\
\hline Bathymetric survey & $\mathrm{x}$ & & $\mathrm{x}$ & & $\mathrm{x}$ & $\mathrm{x}$ & & $\mathrm{x}$ & $\mathrm{x}$ \\
\hline \multicolumn{10}{|c|}{ Potentiometric surface of the Upper Floridan aquifer } \\
\hline $\begin{array}{l}\text { Historical trends in wetland/surficial aquifer } \\
\text { water-level data in relation to water levels in the } \\
\text { Upper Floridan aquifer }\end{array}$ & $\mathrm{x}$ & $\mathrm{x}$ & $\mathrm{x}$ & $\mathrm{x}$ & $\mathrm{x}$ & $\mathrm{x}$ & $\mathrm{x}$ & $\mathrm{x}$ & $\mathrm{x}$ \\
\hline $\begin{array}{l}\text { Historical groundwater withdrawal data within a } \\
\text { 1-mile radius from center of wetland }\end{array}$ & $\mathrm{x}$ & $\mathrm{x}$ & $\mathrm{x}$ & $\mathrm{x}$ & $\mathrm{x}$ & $\mathrm{x}$ & $\mathrm{x}$ & $\mathrm{x}$ & $\mathrm{x}$ \\
\hline $\begin{array}{l}\text { Depth to the potentiometric surface of the Upper } \\
\text { Floridan aquifer below the wetland }\end{array}$ & $\mathrm{x}$ & $\mathrm{x}$ & $\mathrm{x}$ & $\mathrm{x}$ & $\mathrm{x}$ & $\mathrm{x}$ & $\mathrm{x}$ & $\mathrm{x}$ & $\mathrm{x}$ \\
\hline
\end{tabular}

performed using a Professional Explorer (ProEx) system in the manner described by Barr (1993) and Kruse and others (2006). The depth of reflected signals was correlated with geologic data at known reference points.

Wetland water levels were compared to water levels in the underlying aquifers. The analysis incorporated long-term historical monthly to bimonthly groundwater and surfacewater level data collected by the USGS, SWFWMD, and Tampa Bay Water from 1989 to 2009. In addition, groundwater levels at or near all study sites were continuously monitored by the USGS (December 2007 to March 2009) to obtain detailed data on water-level differences for each study wetland (table 3). Water levels were recorded at each wetland using a fully-screened well that monitored surface-water levels during flooded periods and groundwater levels during dry periods. Consequently, several analyses in this report are based on data that represent alternating surface-water and groundwater levels, and the term "wetland/surficial aquifer" is used to describe these measurements. Water levels in the Upper Floridan aquifer also were monitored in the vicinity of each wetland. Pressure transducers and data loggers were used to continuously measure and record water levels in the wetland/surficial aquifer and the Upper Floridan aquifer in accordance with standard methods described in Freeman and others (2004). In addition, rainfall data were collected at seven of the study wetlands from December 2007 to March 2009 to determine if rainfall accumulations at wetland sites were similar. Rainfall was measured by the USGS using storage rain gages, and tipping-bucket rain gages that recorded at 15-minute intervals.

Well characteristics and a data summary for the study wetlands are listed in table 3 , and locations of the monitoring sites are shown in figures $6-8$. Groundwater and surface-water level data collected during this study are available online from the USGS National Water Information System database using the USGS identification number at $h t t p: / / w a t e r d a t a . u s g s . g o v /$ $f l / n w i s / g w / d v /$.

Daily average wetland and aquifer levels were compared directly to help determine the relations between the wetland/ surficial aquifer and Upper Floridan aquifer, and to understand the connection between aquifer units. Linear regression analyses were used to help determine the strength of these water-level relations. The coefficient of determination, $\mathrm{r}^{2}$, indicates how much water-level variability in the wetland/ surficial aquifer is associated with water-level variability in the Upper Floridan aquifer. For example, an $\mathrm{r}^{2}$ value of 0.50 means that 50 percent of the variability in wetland water levels is explained by variability in Upper Floridan aquifer levels. A significant statistical relation indicates a high degree of interconnection between the two aquifers 
Table 3. Well characteristics and other data collected at the study wetlands.

[USGS, U.S. Geological Survey; SW, surface water; SA, surficial aquifer, UFA, Upper Floridan aquifer; CWR, continuous water-level recorder; WL, periodic water level; —, unknown casing depth; na, not applicable]

\begin{tabular}{|c|c|c|c|c|c|c|}
\hline $\begin{array}{l}\text { Index } \\
\text { number }\end{array}$ & Identification number & Name & $\begin{array}{l}\text { Total well } \\
\text { depth } \\
\text { (feet) }\end{array}$ & $\begin{array}{l}\text { Total well cased } \\
\text { interval } \\
\text { (feet) }\end{array}$ & $\begin{array}{c}\text { Hydrologic } \\
\text { unit }\end{array}$ & $\begin{array}{c}\text { Data } \\
\text { summary }\end{array}$ \\
\hline
\end{tabular}

Cypress Bridge well field

\begin{tabular}{|c|c|c|c|c|c|c|}
\hline 1 & 281325082215301 & FL-2-1000 & 704 & 186 & UFA & CWR \\
\hline 2 & 281327082215401 & CYB WT 2-1000 & 14 & - & SA & WL \\
\hline 3 & 281320082220701 & CYB-01 Sink 2 & 5 & 5 & SA & CWR \\
\hline 4 & 281320082220700 & CYB-01 Crest Stage Indicator & na & na & SW & WL \\
\hline 5 & 281319082220701 & CYB-01 $13 \mathrm{ft}$ & 13 & - & SA & CWR \\
\hline 6 & 281318082220701 & CYB-01 Sink 1 & 16 & 11 & UFA & CWR \\
\hline $6 \mathrm{~A}$ & 281318082220700 & CYB-01 rain gage & na & na & na & Rain \\
\hline
\end{tabular}

Cypress Creek well field

\begin{tabular}{|c|c|c|c|c|c|c|}
\hline 7 & 281637082233201 & CCWF-829D & 52 & 49 & UFA & CWR \\
\hline 8 & 281637082233202 & CCWF-829S & 14 & - & SA & WL \\
\hline 9 & 281635082233501 & CCWF-W33A & 6 & - & $\mathrm{W} / \mathrm{SA}$ & CWR \\
\hline 10 & 281635082233502 & CCWF-W33 & 9 & - & SA & WL \\
\hline 11 & 281637082233700 & CCWF-W33 Rain & na & na & na & Rain \\
\hline 12 & 281723082233602 & CCWF BIO-4 & 15 & - & $\mathrm{W} / \mathrm{SA}$ & WL \\
\hline 13 & 281722082233401 & CCWF W-16 USGS Center & 19 & 9 & W/SA & CWR \\
\hline 14 & 281723082233601 & CCWF W-16 Upland & 21 & 11 & SA & CWR \\
\hline 15 & 281729082234100 & CCWF W-12 rain gage & na & na & na & Rain \\
\hline 16 & 281731082233901 & CCWF W-12 Upland & 14 & - & SA & CWR \\
\hline 17 & 281733082234001 & CCWF W-12 INT & 18 & - & SA & CWR \\
\hline 18 & 281733082234002 & CCWF-W12A & 8 & - & SA & WL \\
\hline 19 & 281726082234601 & CCWF 826 Deep & 37 & 32 & UFA & CWR \\
\hline 20 & 281726082234602 & CCWF 826 Shallow & 11 & - & SA & WL \\
\hline 21 & 281622082241301 & Cypress Creek Deep 3 & 352 & 136 & UFA & CWR, Rain \\
\hline 22 & 281622082241801 & CCWF G WTL & 6 & - & SA & CWR \\
\hline 23 & 281622082242001 & CCWF G UPL & 7 & - & SA & CWR \\
\hline 24 & 281622082242002 & CCWF BIO-6 & 11 & - & SA & WL \\
\hline $24 \mathrm{~A}$ & 281746082233701 & CCWF-TMR-3 Deep & 625 & 160 & UFA & CWR \\
\hline $24 \mathrm{~B}$ & 281746082233702 & CCWF-TMR-3 Shallow & 11 & 7 & SA & CWR \\
\hline $24 \mathrm{C}$ & 281650082244501 & CCWF-TMR-4 Deep & 592 & 99 & UFA & CWR \\
\hline $24 \mathrm{D}$ & 281650082244501 & CCWF-TMR-4 Shallow & 24 & 20 & SA & CWR \\
\hline \multicolumn{7}{|c|}{ Starkey well field } \\
\hline 25 & 281418082343001 & Starkey S-68 CTR & 3 & 3 & $\mathrm{~W} / \mathrm{SA}$ & CWR \\
\hline 26 & 281421082343101 & Starkey S-68 UNW NRSD & 14 & 10 & SA & CWR \\
\hline 27 & 281421082343102 & Starkey S-68 FLRD & 130 & 80 & UFA & CWR, Rain \\
\hline 28 & 281442082354901 & STWF 1A Central & 100 & 98 & UFA & CWR, Rain \\
\hline 29 & 281442082354902 & STWF 1B Central & 13 & 5 & SA & WL \\
\hline 30 & 281442082354903 & STWF 1C Central & 7 & 6 & SA & WL \\
\hline 31 & 281442082351601 & STWF Central & 30 & 5 & SA & WL \\
\hline 32 & 281441082354601 & STWF 2B Central & 30 & 8 & SA & CWR \\
\hline 33 & 281441082354401 & STWF 3A Central & 21 & 20 & SA & WL \\
\hline
\end{tabular}


Table 3. Well characteristics and other data collected at the study wetlands.-Continued

[USGS, U.S. Geological Survey; SW, surface water; SA, surficial aquifer, UFA, Upper Floridan aquifer; CWR, continuous water-level recorder; WL, periodic water level; —, unknown casing depth; na, not applicable]

\begin{tabular}{|c|c|c|c|c|c|c|}
\hline $\begin{array}{l}\text { Index } \\
\text { number }\end{array}$ & Identification number & Name & $\begin{array}{l}\text { Total well } \\
\text { depth } \\
\text { (feet) }\end{array}$ & $\begin{array}{l}\text { Total well cased } \\
\text { interval } \\
\text { (feet) }\end{array}$ & $\begin{array}{c}\text { Hydrologic } \\
\text { unit }\end{array}$ & $\begin{array}{l}\text { Data } \\
\text { summary }\end{array}$ \\
\hline 34 & 281441082354402 & STWF 3B Central & 11 & 1 & SA & WL \\
\hline 35 & 281441082354403 & STWF 3C Central & 6 & 1 & SA & WL \\
\hline 36 & 281449082362501 & STWF 1A West & 95 & 85 & UFA & CWR, Rain \\
\hline 37 & 281449082362502 & STWF 1B West & 16 & 5 & SA & WL \\
\hline 38 & 281449082362503 & STWF 1C West & 23 & 15 & SA & WL \\
\hline 39 & 281449082362504 & STWF 1D West & 10 & 5 & SA & WL \\
\hline 40 & 281449082362301 & STWF 2A West & 56 & 46 & SA & WL \\
\hline 41 & 281449082362302 & STWF 2B West & 31 & 26 & $\mathrm{~W} / \mathrm{SA}$ & CWR \\
\hline 42 & 281449082362303 & STWF 2C West & 18 & 13 & SA & CWR \\
\hline 43 & 281448082362101 & STWF 3A West & 23 & 22 & SA & WL \\
\hline 44 & 281448082362102 & STWF 3B West & 30 & 25 & SA & WL \\
\hline 45 & 281448082362103 & STWF 3C West & 10 & 5 & SA & WL \\
\hline 46 & 281500082350402 & Starkey 10 deep & 392 & 153 & UFA & CWR \\
\hline 47 & 281427082382802 & Starkey 728 Shallow & 18 & 17 & SA & CWR \\
\hline $47 \mathrm{~A}$ & 281447082354302 & SM-2 Shallow & 18 & 17 & SA & WL \\
\hline \multicolumn{7}{|c|}{ Other study wells } \\
\hline 48 & 281558082264601 & Pasco 13 & 49 & 43 & UFA & CWR \\
\hline 49 & 281636082372001 & Moon Lake Deep & 115 & 65 & UFA & CWR \\
\hline 50 & 281715082164401 & State Hwy 577 & 150 & 57 & UFA & CWR \\
\hline 51 & 281949082332001 & State Hwy 52 & 73 & 60 & UFA & CWR \\
\hline
\end{tabular}

$\left(\mathrm{r}^{2}=1.00\right)$. The linear regressions presented are all significant to an alpha level of 0.05 , which corresponds to a 95 -percent confidence interval.

To understand the effects of groundwater withdrawals on the hydrology of each wetland, pumpage records were examined for the total period-of-record for individual well fields (Robert Peterson, Southwest Florida Water Management District, unpub. data, 2009). In addition, the combined withdrawal rate within a 1-mi radius from the center of each study wetland was examined to determine how the withdrawals affected the hydrology of the individual wetlands. The 1-mi-radius combined withdrawal rates were then compared among study wetlands.

Long-term hydrographs and water-level trends for the surficial and Upper Floridan aquifers at both Starkey and Cypress Creek well fields were examined to help determine when impacts to wetlands may have occurred and if there was a substantial recovery in water levels. Statistical analyses were performed on the water-level data to determine trends for each aquifer. Linear regression analysis and the distance-weighted least-squares fitting method (McLain, 1974) were used to help determine trends in aquifer water levels.
Generalized elevation-difference maps were created for Starkey and Cypress Creek well fields to define the groundwater conditions prior to and after groundwater development at these well fields. Land-surface elevation data obtained in 2005 using LIDAR (Furgo Earthdata, Inc, 2010) were used to map the distance of the potentiometric surface of the Upper Floridan aquifer below the study wetlands. LIDAR data were provided by the SWFWMD for this analysis. Elevationdifference maps prior to groundwater development were created by subtracting the estimated potentiometric surface of the Upper Floridan aquifer prior to groundwater development (Johnston and others, 1980; app. 1) at the Starkey and Cypress Creek well fields from the recent land-surface elevation LIDAR data. Elevation-difference maps also were created for current (2008-09) pumping conditions at both well fields by subtracting the potentiometric surface of the Upper Floridan aquifer in September 2008 and May 2009 (apps. 2 and 3, respectively) from the LIDAR data. Box plots were used to compare the historical and current levels of the Upper Floridan aquifer to the study wetland-bottom elevation prior to and after groundwater withdrawals were reduced at both well fields. 
To compare and contrast the hydrologic condition of the wetlands prior to and after the reduction in groundwater withdrawals at the Starkey and Cypress Creek well fields, flooded-area maps and frequency-distribution graphs were developed for four study wetlands: an unimpacted wetland, a minimally impacted wetland, and two severely impacted wetlands. Bathymetric data and historical wetland/surficial aquifer levels were used to create the flooded-area maps and frequency-distribution graphs.

A ranking system was used to determine the cumulative effect of the factors that influence the hydrologic recovery of wetlands. Ranking for three of the four factors (topographic setting, permeability of sediments underlying wetlands, and depth to the potentiometric surface of the Upper Floridan aquifer below the wetlands) was based on whether each factor had a positive influence, a neutral influence, or a negative influence. Ranking for the remaining factor (karst feature near or underlying wetland) was based on whether karst features were absent, near, or underlying the study wetland.

\section{Factors that Influence the Hydrologic Recovery of Wetlands}

The following sections examine the four factors that influence the hydrologic recovery of wetlands in the study area, including: (1) the topographic setting, (2) the permeability of the sediments underlying the wetlands, (3) recent karst activity, and (4) the depth to the potentiometric surface of the Upper Floridan aquifer underlying the wetland.

Examples from all or subsets of the study wetlands are used to demonstrate how each factor influences the hydrology of the wetlands. The effects of these factors on each of the study wetlands are then ranked to show the relative magnitude of each factor in relation to the wetland's potential to recover when groundwater withdrawals are reduced.

\section{Topographic Setting}

In the low-lying topographic setting of the study area, subtle elevation differences can influence the flow patterns of surface water and groundwater around wetlands. For example, if a wetland is topographically lower in the landscape than the surrounding areas, surface-water connections are made more easily to other wetlands and to other surface-water bodies through low-lying surface-water channels (fig. $4 A-B$ ). In addition, wetlands that are farther downgradient in a watershed drainage system are more likely to receive runoff from a larger contributing area than wetlands at higher elevations in the watershed (Lee and others, 2010).

Several of the study wetlands have benefited from their position in a low-lying topographical setting. For example, S-68 Cypress is located near low-gradient surface-water channels and receives overland flow from surrounding areas and upgradient wetlands during high rainfall periods (fig. 9A). Daily water-budget results from Lee and others (2009) provide insights into the importance of this surface runoff to the hydrology of the isolated wetland. During periods when S-68 Cypress was gaining water in excess of direct rainfall, the daily increase in wetland volume was 1.74 times the daily rainfall volume.

Wetlands that are topographically lower in the drainage basin and have surface-water connections had longer wetland hydroperiods than wetlands with no surface-water connections. Comparisons of water levels were made for two severely impacted wetlands (W-12 Cypress and W-16 Marsh; fig. $9 B$ ) that are located in the same area of the well field and have similar geology and elevation of the potentiometric surface underlying the wetland. During the high rainfall period of 2003-2005, W-12 Cypress was connected to other wetlands and had a longer hydroperiod in comparison to the nearby W-16 Marsh. The area surrounding W-12 Cypress is about $5 \mathrm{ft}$ lower in elevation than $\mathrm{W}-16 \mathrm{Marsh}$, and the wetland is lower relative to the nearest surface-water bodies. Surface-water connections to nearby isolated wetlands and surface-water bodies are made more easily through localized low-gradient surface-water channels for $\mathrm{W}-12$ Cypress than $\mathrm{W}-16$ Marsh; thus extending the duration and volume of surface-water inflow that the wetland receives.

The topographic setting also influences the groundwater flow patterns surrounding and underlying the study wetlands. Relatively low-lying wetlands surrounded by uplands have a greater potential to be in either a groundwater discharge or flow-through setting (fig. $3 B$ or $C$ ), and benefit from greater groundwater inflow or reduced leakage than wetlands in higher topographic settings. In a study by Lee and others (2009), the eastern side of W-19 Impaired Cypress was topographically higher than the western side, and the wetland received groundwater inflow from the higher side because the water table was close to land surface and higher than the wetland water level. As a result of this topographic setting, W-19 Impaired Cypress received greater groundwater inflow than other wetlands in that study, which were typically in recharge settings. W-19 also had the highest volume ratio of runoff to rainfall of the 10 wetlands analyzed in that study.

Separating the effects of differences in topographic setting on the potential for wetland recovery from other factors is difficult, because information on how subtle differences in topography can affect surface and groundwater flow to and from wetlands, and data on flows between wetlands, are not available. Studying wetlands on well fields is further complicated by the effects of pumping. Integrated modeling combined with LIDAR data is a promising methodology for quantifying these effects over broad wetland landscapes (Lee and others, 2010). When all other factors that influence the hydrologic condition of wetlands are the same, wetlands in a low-lying topographic setting have a greater potential to recover when groundwater withdrawals are reduced. 
A

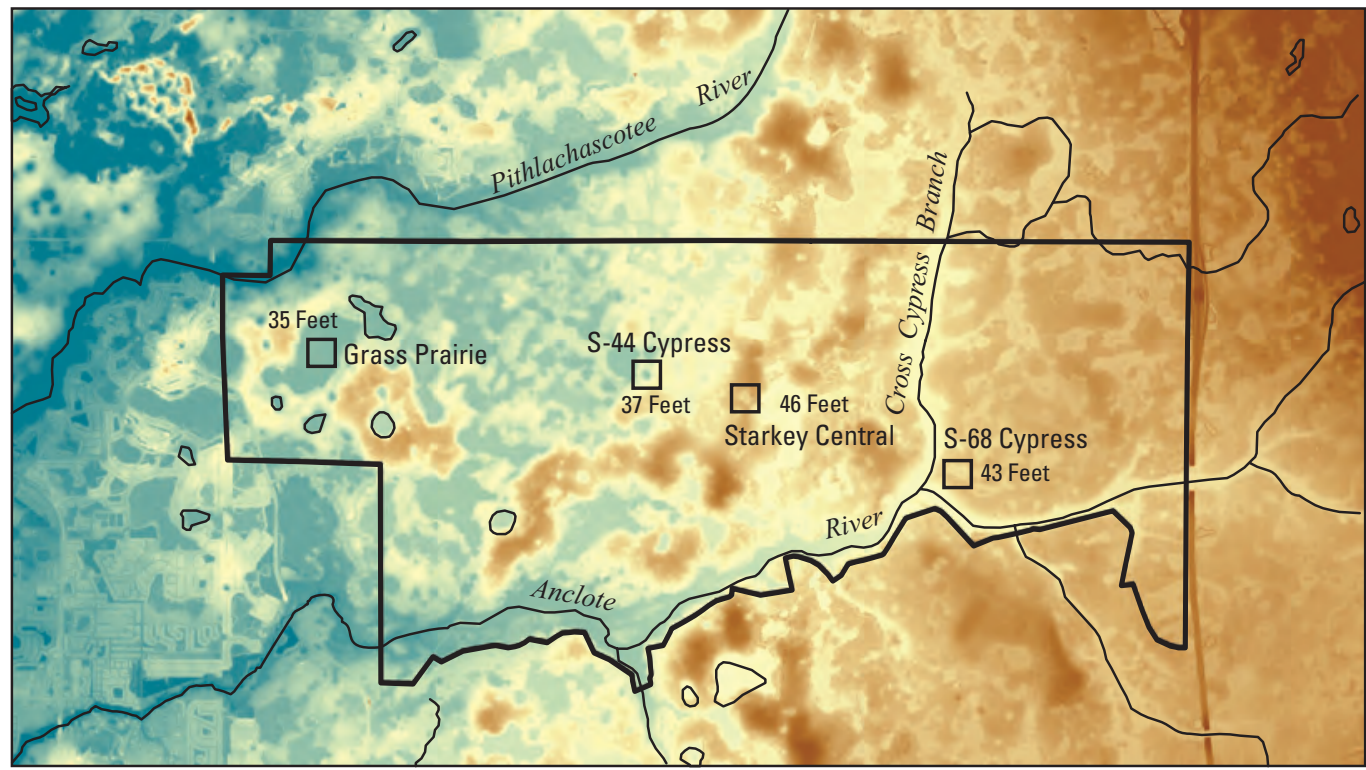

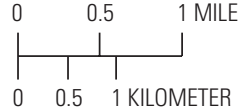

B

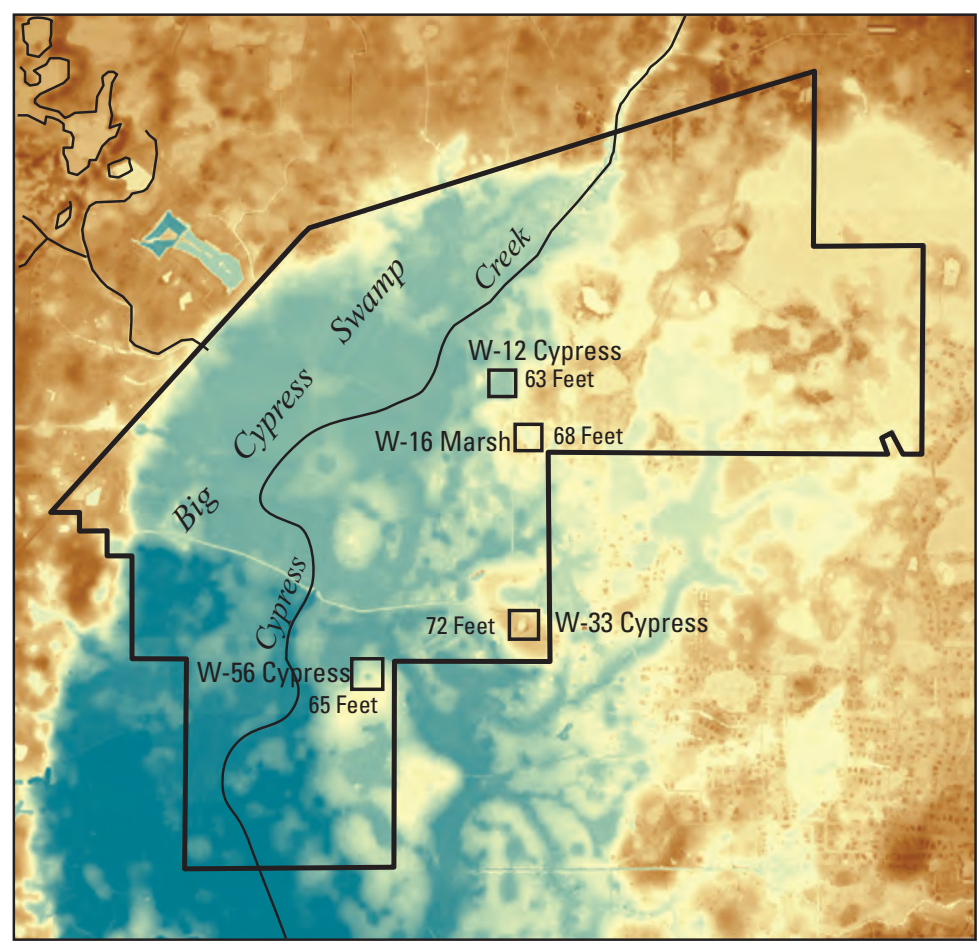

Elevation, in feet above NGVD 1929
$\mathbf{N}$

1

\section{EXPLANTION \\ Well-field boundary \\ S-68 Cypress Study wetlands - Name \\ $\square \quad$ and approximate elevation 43 Feet of surrounding area.}

Elevation, in feet above NGVD 1929
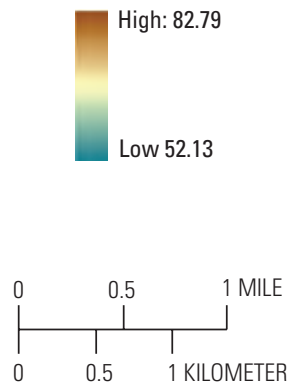

Figure 9. Light detection and ranging (LIDAR) digital elevation maps showing topography surrounding the study wetlands at the $A$, Starkey, and $B$, Cypress Creek well fields. 


\section{Hydrogeologic Setting}

The hydrogeologic setting beneath a wetland can substantially affect its potential for water-level recovery. Two aspects of the hydrogeology that affect wetland waterlevel recovery are the permeability of the sediments underlying wetlands, and the presence of karst features underlying or near the wetland.

\section{Permeability of Sediments Underlying the Wetlands}

Wetlands in the study area form in shallow saucer-shaped depressions in the mantled karst landscape (Sinclair, 1982). The low permeability layers that typically underlie these wetlands help retard the downward movement of water from the wetlands to the underlying Upper Floridan aquifer (Lee and others, 2009). The restriction of flow can create a lens or shallow groundwater recharge mound beneath a wetland that expands and contracts depending on hydrologic conditions (Lee and others, 2009).

Several components of the hydrogeologic framework help maintain the hydrology of shallow depressional wetlands in the study area, including (1) a thin clay layer in the nearsurface wetland-bottom sediments that slows the downward movement of water from the wetland (fig. 10A; Lee and others, 2009); (2) a clay or hard-pan layer that lies about 5 to $10 \mathrm{ft}$ below the wetland and retards the downward movement of groundwater (fig. 10A; Lee and others, 2009); and (3) an intact or thick clay layer of low permeability, referred to as the intermediate confining unit, that slows the movement of water between the wetland/surficial aquifer and the Upper Floridan aquifer (fig. 10A; Metz and Sacks, 2002; Lee and others, 2009). For wetlands that reside in a groundwater recharge setting in the study area, these low permeability layers help sustain the wetland water levels by slowing the vertical leakage between the wetland and the underlying aquifers.

Clay and organic matter in the wetland-bottom sediments are an important component of the wetland geology, and the thickness, structure, and consistency of these sediments varied widely among study wetlands (fig. 11). The top $2 \mathrm{ft}$ of organic material collected from six of the study wetlands was (1) fibrous and matted (S-68, W-33, and W-56 Cypress wetlands), (2) peat and mud-like in consistency (S-44 Cypress and Grass Prairie wetlands), and (3) a sandy organic layer devoid of any fibrous and matted material (W-16 Marsh). Underlying the top organic sediments are mottled soils that contain dark stains or streaks. These mottled soils may indicate water-table fluctuations, poor surface drainage, or biological mixing (Tiner, 1999).

Grain-size analysis of the top $2 \mathrm{ft}$ of the wetland-bottom sediments indicates a generally decreasing trend in the organic matter (silt) with depth (fig. 11B). For some wetlands, a relatively thin clay-rich layer is present at the upper surface of the wetland-bottom sediments. In low-energy environments such as wetlands, fragments of organic matter act as a substrate for the adherence of settling clay particles, allowing them to accumulate (Mitsch and Gosselink, 2000). These near-surface clays in the wetland-bottom sediments helped slow the movement of water from the wetland, and the relative percentage of clays ranged from about 2 to 5 percent. The lowest percentage of near-surface clays was at the minimally impacted W-56 Cypress ( 2 percent), whereas the highest percentage of near-surface clays was at the relatively unimpacted S-68 Cypress and the severely impacted S-44 Cypress (about 4 and 5 percent, respectively; fig. 11C).

The vibracores collected at six of the study wetlands provided insight into the variability of the low permeability layers underlying the wetland-bottom sediments (fig. 12A). These cores were collected until the impenetrable clay or hardpan layer below the wetland bottom was encountered, which ranged in depth from about 6 to $10 \mathrm{ft}$. At W-33 Cypress and Grass Prairie wetlands, a dense green-gray clay unit (fig. 12B) was encountered about 6 and $8 \mathrm{ft}$ below the wetland bottom, respectively. At W-56 Cypress and S-68 Cypress, a tan colored, sandy-clay layer (fig. 12C) was encountered at about 6 and $8 \mathrm{ft}$ below the wetland bottom, respectively. At S-44 Cypress, the core consisted of over $8 \mathrm{ft}$ of peat-like material, followed by $1 \mathrm{ft}$ of white sand, and by an impenetrable sandy-clay layer at about $10 \mathrm{ft}$. At W-16 Marsh, an impenetrable, clayey iron-stained layer was encountered about $4.5 \mathrm{ft}$ below the wetland bottom (fig. 12D).

Grain-size analysis of the sediments indicated that clay content increased with depth below five of the six study wetlands that were cored. As described earlier, these lowpermeability layers provide a mechanism to slow vertical groundwater flow so that water tends to accumulate or moundup underneath the wetlands. For Grass Prairie, W-16 Marsh, S-68 Cypress, and S-44 Cypress wetlands, clay percentages were greatest from about 3 to $10 \mathrm{ft}$ below land surface, and ranged from about 6 to 10 percent (fig. 11C). At W-56 Cypress, clay content ranged from about 2 to 3 percent and did not increase substantially with depth.

Another low permeability layer present beneath the wetlands is the intermediate confining unit, which separates the wetland/surficial aquifer from the Upper Floridan aquifer. This unit is about 20 to $30 \mathrm{ft}$ below the study wetlands and its thickness varies throughout the study area (fig. 13). In the Cypress Creek well field, the confining unit thickness ranges from less than $25 \mathrm{ft}$ along the southeastern boundary to about $50 \mathrm{ft}$ near the northeastern boundary. The intermediate confining unit is less than 25 - $\mathrm{ft}$ thick beneath the Starkey and Cypress Bridge well fields.

Natural-gamma logs combined with lithologic data for wells near four of the study wetlands were used to delineate the sand to clayey sand layers and the position of the intermediate confining unit, which is composed mainly of sandy clay at these sites (fig. 14A-D). The underlying lithology at Starkey and Cypress Creek well fields shown in figure $14 A-D$ 
$\boldsymbol{A}$

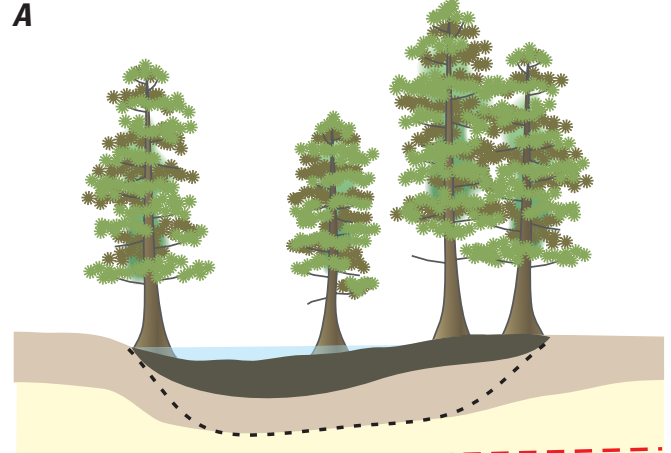

Shallow depth to the potentiometric surface of the

Upper Floridan aquifer below the wetland-bottom elevation

Intermediate confining unit is thick, intact, and has low permeability

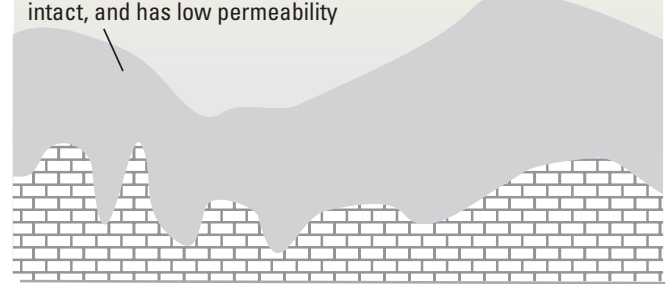

NOT TO SCALE

C

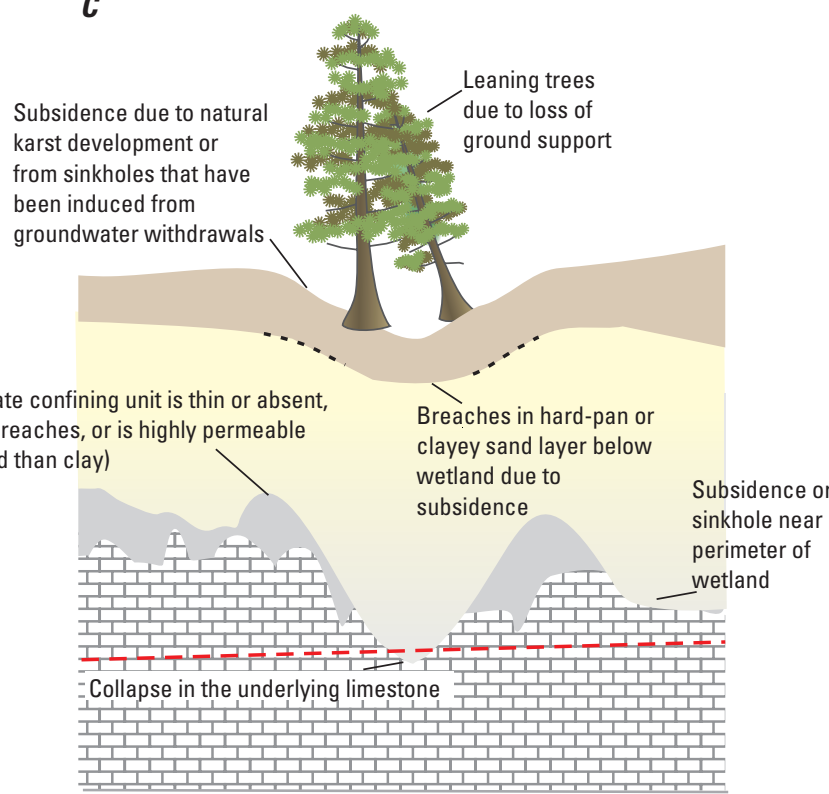

NOT TO SCALE

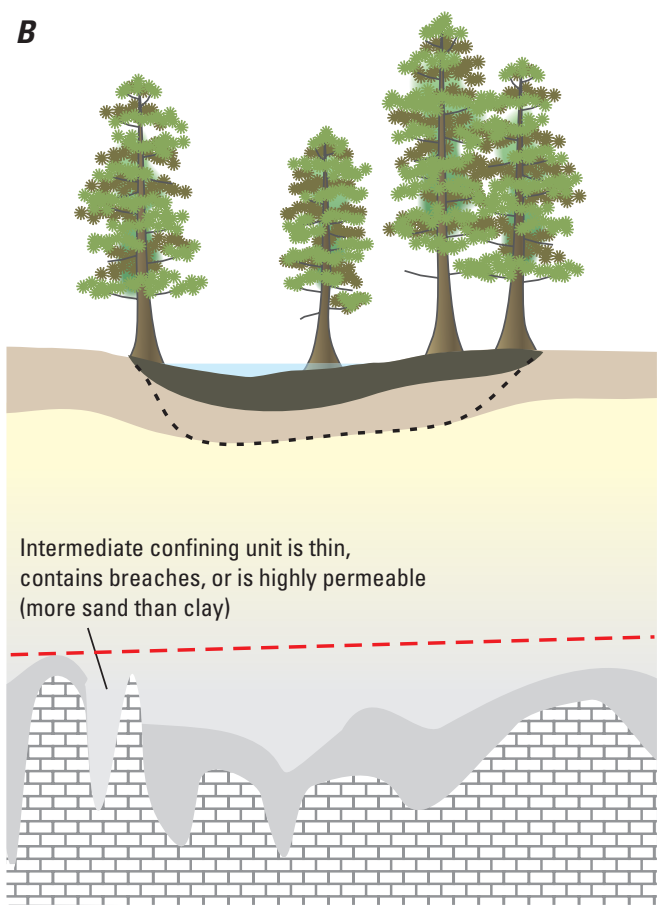

NOT TO SCALE

D

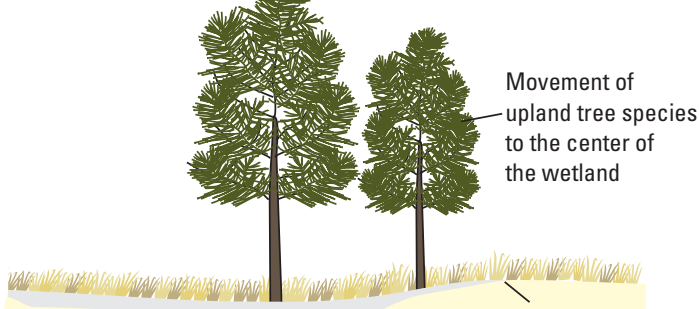

Loss of wetland sediments caused by drying and compaction or by intense fires

Encroachment of upland species

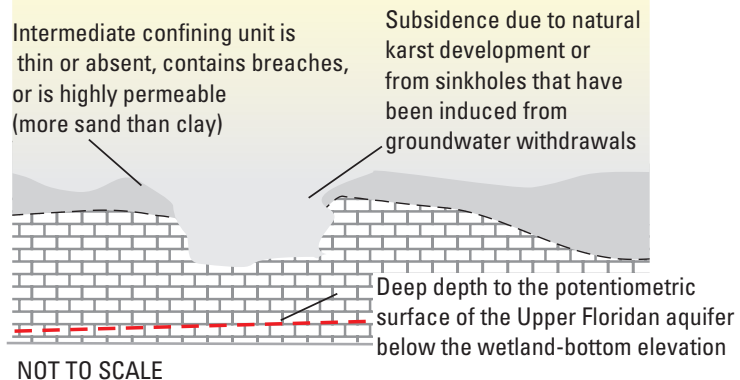

\section{EXPLANATION}

\begin{tabular}{|c|c|c|c|}
\hline $\begin{array}{r}\text { Surficial } \\
\text { aquifer }\end{array}$ & & $\begin{array}{l}\text { Wetland sediment - Includes a thin clay layer } \\
\text { in the top of the soft organic sediments. } \\
\text { Sand and organics } \\
\text { Sand with increasing clay content with depth. }\end{array}$ & 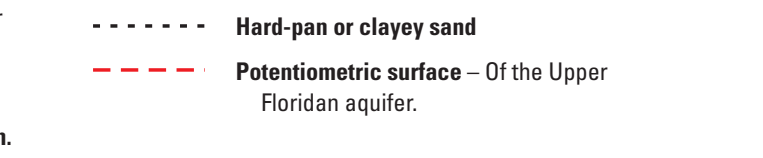 \\
\hline $\begin{array}{r}\text { Intermediate } \\
\text { confining unit } \\
\text { Upper Floridan } \\
\text { aquifer }\end{array}$ & 只 & Sand, clay, and carbonate mud & $\begin{array}{l}\text { Figure 10. Generalized hydrogeologic sections showing } \\
A \text {, an unimpacted to minimally impacted wetland, } B \text {, a } \\
\text { moderately impacted wetland, and } C-D \text {, two severely } \\
\text { impacted wetlands. }\end{array}$ \\
\hline
\end{tabular}



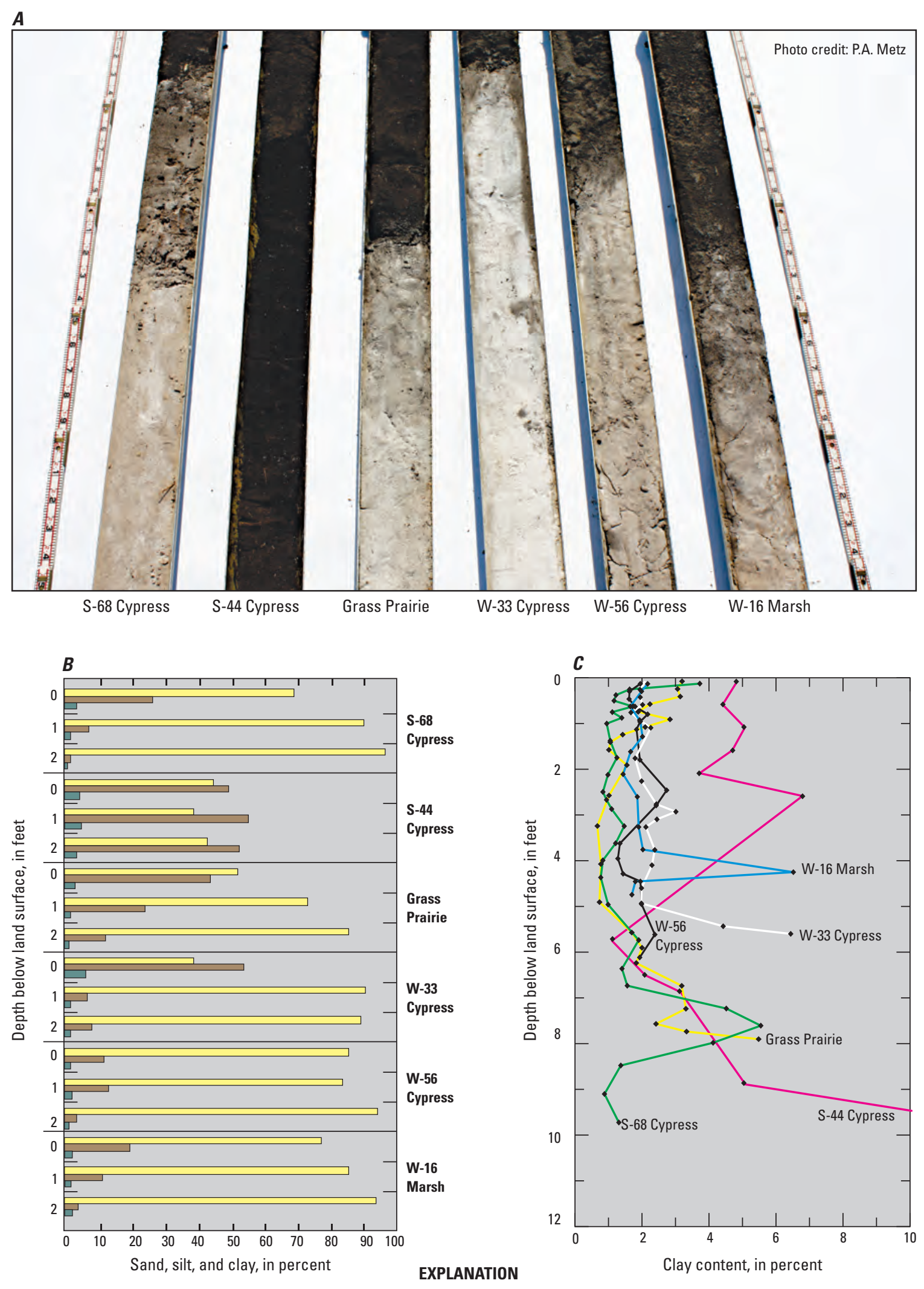

Sand $\square$ Silt-Organics

Clay Depth of grain-size analysis test for clay

Figure 11. Photographs showing $A$, vibracore samples, and graphs showing $B$, percentage of sand, silt, and clay in the upper 2 feet of wetland sediments, and $C$, clay content at and below land surface for six of the study wetlands. 


\section{A. Grass Prairie}

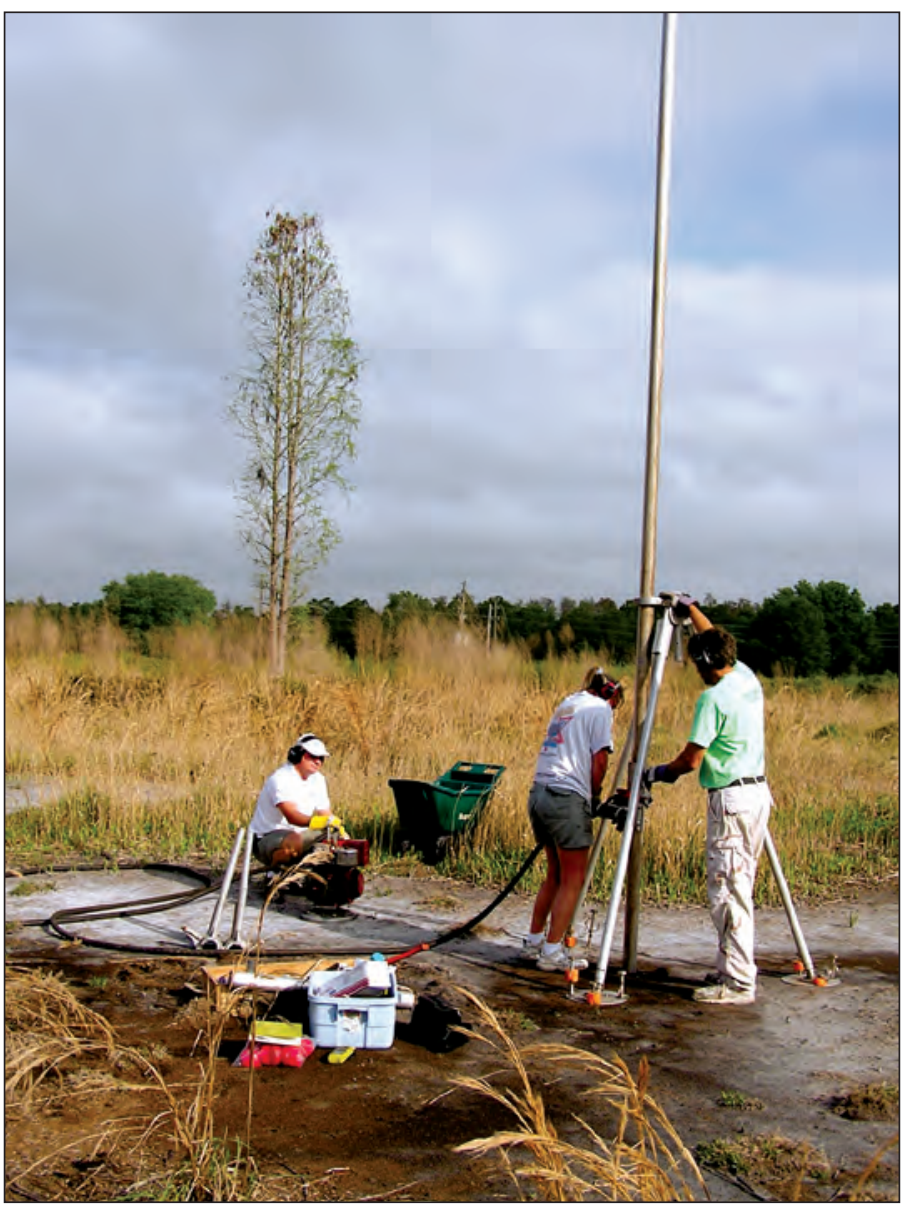

Photo credit: P.A. Met

\section{B. W-33 Cypress}

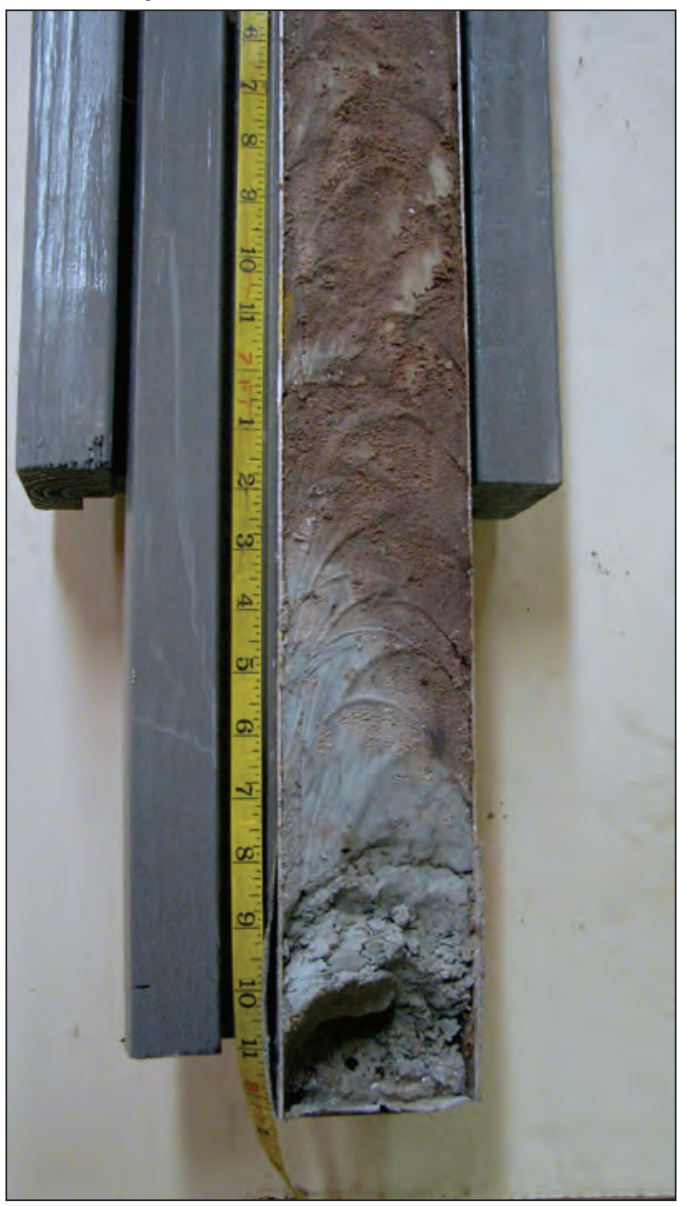

Photo credit: P.A. Metz

\section{S-68 Cypress}

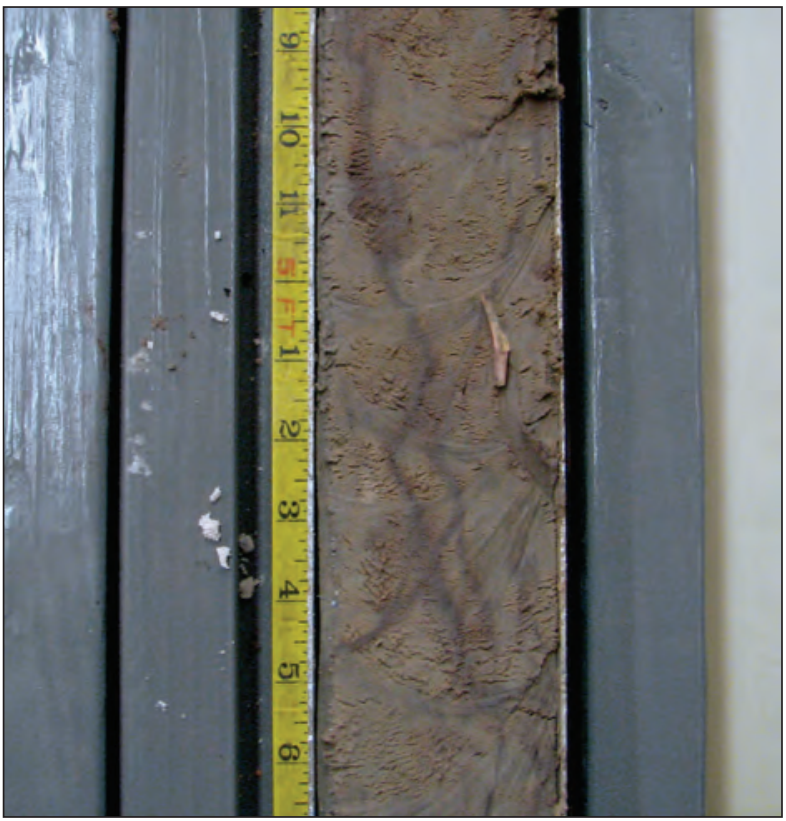

Photo credit: P.A. Metz

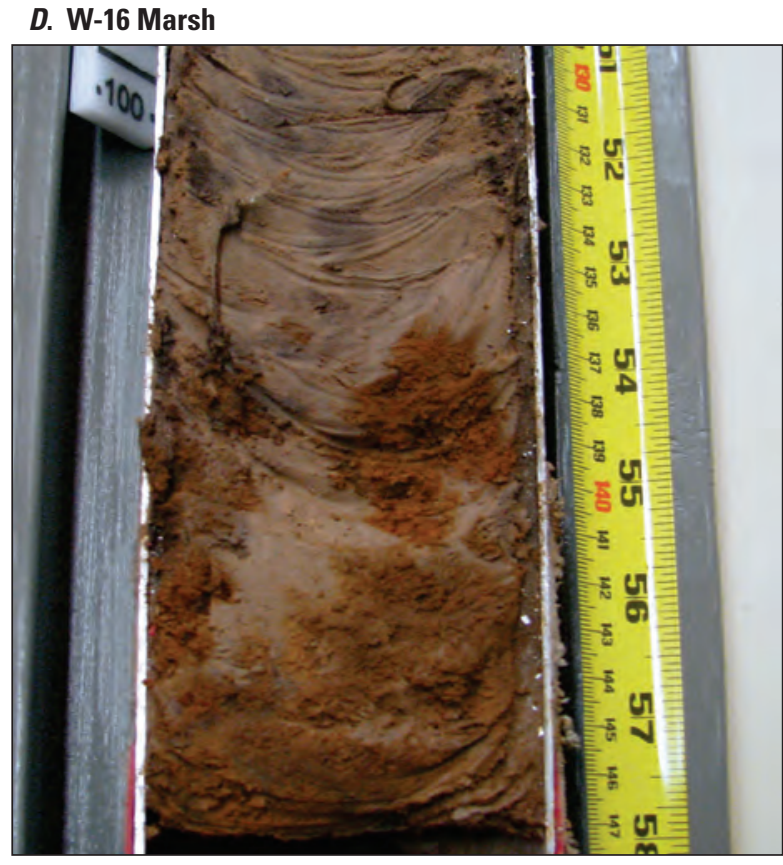

Photo credit: P.A. Metz

Figure 12. Photographs showing $A$, vibracore sample collection, and $B-D$, core samples highlighting the variability of the clay layers in cores beneath the study wetlands. 


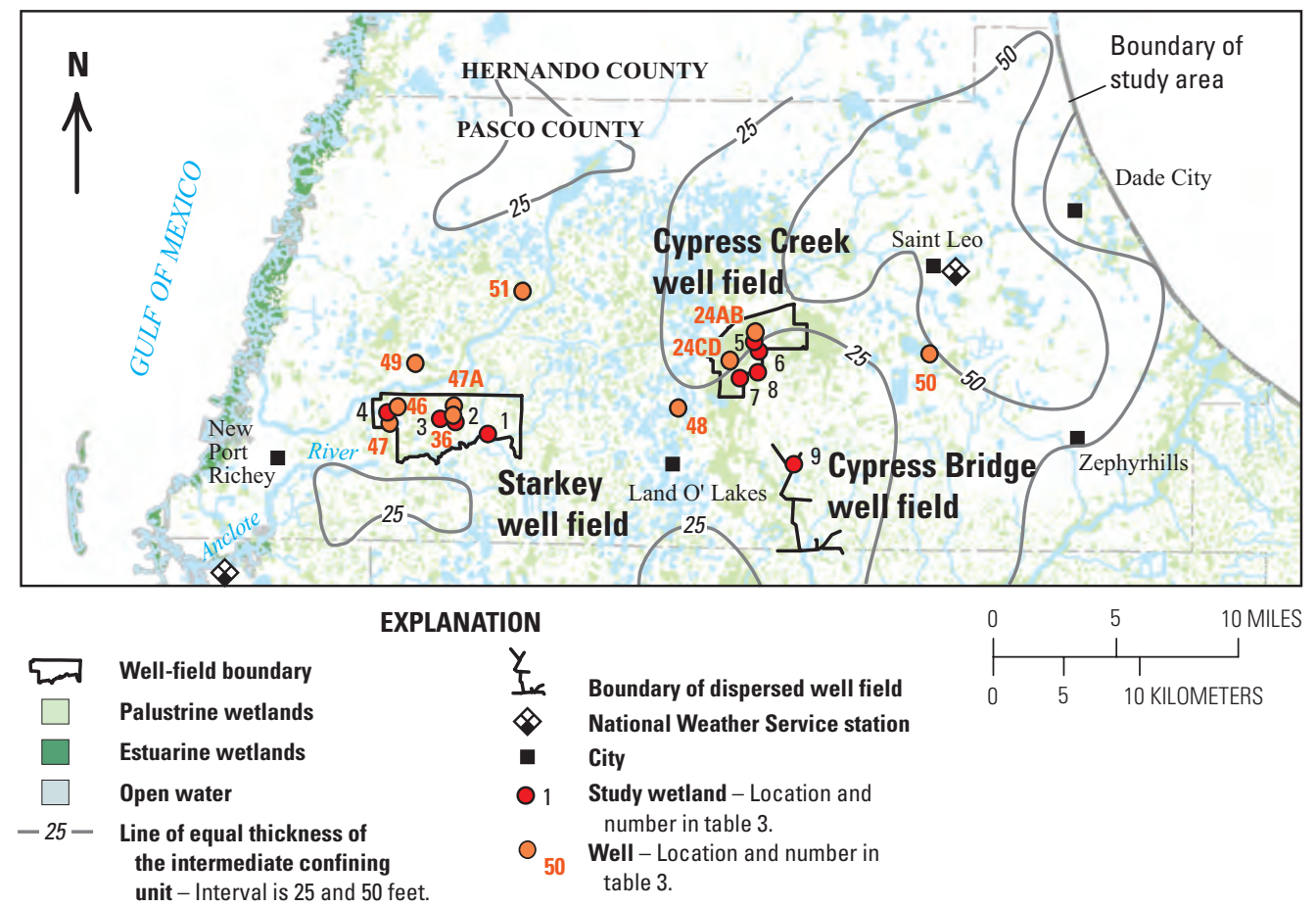

Figure 13. Generalized thickness of the intermediate confining unit overlying the Upper Floridan aquifer. Modified from Buono and others (1979).

indicates the variability in the clay content with depth within and between sites, as shown by the fluctuations in the naturalgamma log signatures, vertical hydraulic conductivity values, and by the grain-size analysis.

The variability of the underlying sediments is reflected by the differences in vertical hydraulic conductivity values between wetland sites and well fields. Vertical hydraulic conductivity, as used herein, is a measure of the ease by which water moves downward through pore spaces of the sediments underlying wetlands, quantified in feet per day. The vertical hydraulic conductivity controls the movement of water between the wetland/surficial aquifer and the Upper Floridan aquifer.

Where the vertical hydraulic conductivity is relatively high, ranging from about 1 to 10 feet per day (ft/d), water moves easily through the sand layers (fig. $14 B-C$ ). As water moves downward into the clayey sand to sandy clay layers, however, the vertical movement slows as hydraulic conductivity decreases. The vertical hydraulic conductivity in the upper clayey sand layers ranges from $10^{-1}$ to $10^{-4} \mathrm{ft} / \mathrm{d}$, and in the sandy clay layers of the intermediate confining unit, it ranges from $10^{-2}$ to $10^{-6} \mathrm{ft} / \mathrm{d}$ (fig. $14 A-C$ ). The vertical hydraulic conductivity of the sandy clay layers in the intermediate confining unit was lowest $\left(10^{-6} \mathrm{ft} / \mathrm{d}\right)$ near the minimally impacted W-33 Cypress at the Cypress Creek well field (fig. 14A), and was highest $\left(10^{-2}\right.$ to $\left.10^{-3} \mathrm{ft} / \mathrm{d}\right)$ near the severely impacted S-44 Cypress at Starkey well field (fig. 14C).

The hydrogeologic analysis of the study wetlands shows the large variability in the permeability of the sediment layers underlying the wetlands. The recovery of water levels for a particular wetland will be different, depending on the permeability of the underlying sediments.

\section{Influence of Karst Features on Wetland Hydrology}

Numerous localized surface or buried depressions (collapsed features or sinkholes) are common throughout the mantled karst landscape and contribute to the highly variable geologic framework of the study area. Sinkholes develop when acidic waters percolate downward, dissolving the underlying limestone, and eventually forming cavities in the limestone substrate. As the cavities expand, the overlying sand and clay subside into solution openings forming depressions of varying sizes and depths in the land surface. 


\section{EXPLANATION}

Natural-gamma log - In counts per second. Increased signature corresponds to clay content.

Clay content - Additional values obtained from grain-size analysis from Hutchinson (2003) and Lee and others (2009).

Vertical hydraulic conductivity Values obtained from falling-head permeameter tests by Hutchinson (2003).

\section{A. W-33 Cypress}

Clay content, in percent

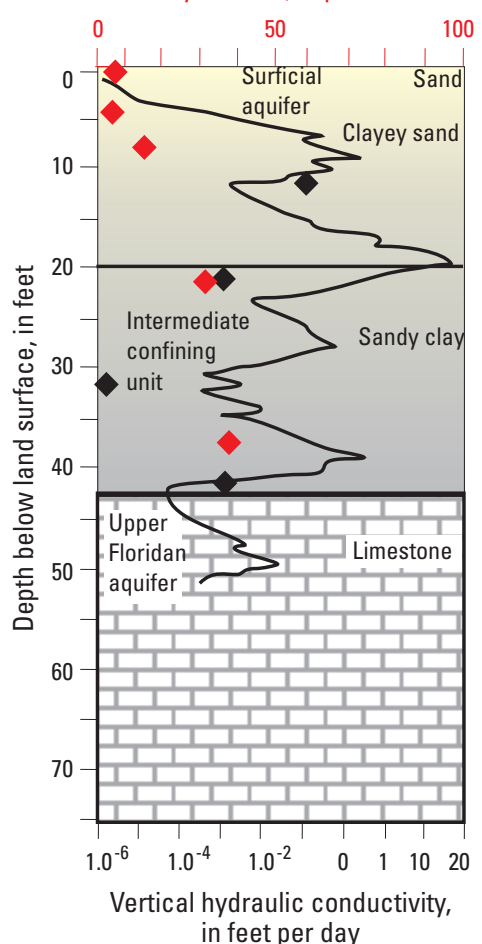

\section{S-44 Cypress and} Starkey Central

Clay content, in percent

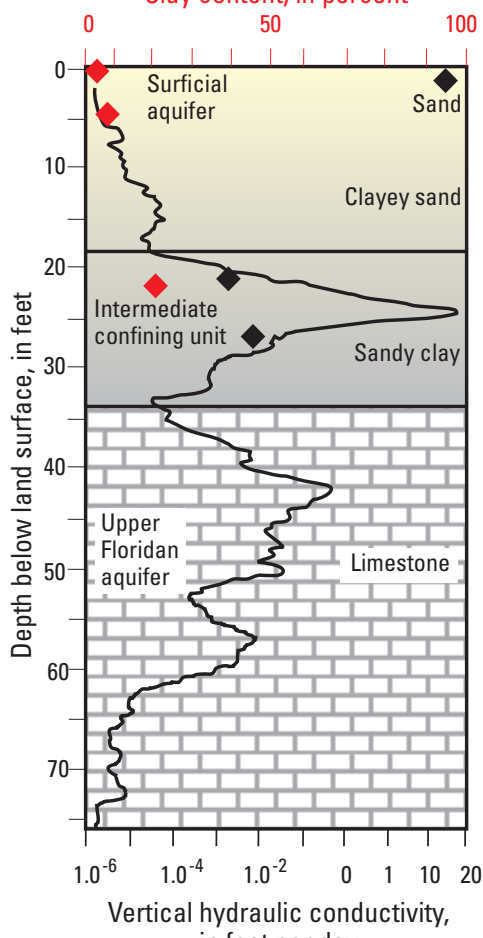

B. W-12 Cypress and W-16 Marsh

Clay content, in percent

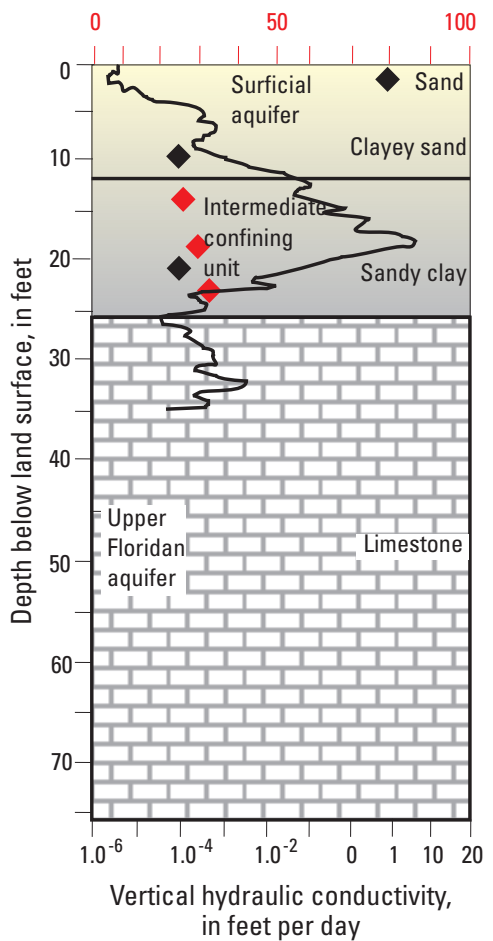

\section{S-68 Cypress}

Clay content, in percent

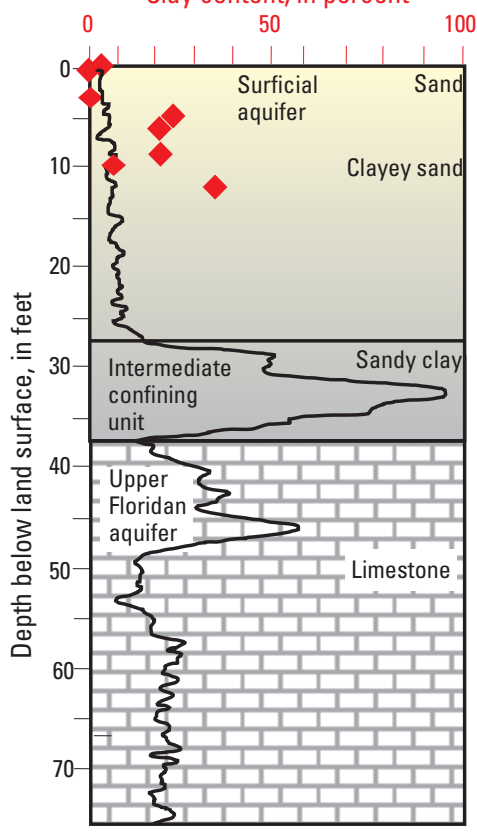

Vertical hydraulic conductivity values are not available

$$
\text { in feet per day }
$$

Figure 14. Geologic and natural-gamma logs showing the variability in the clay units near the study wetlands at the $A-B$, Cypress Creek, and $C-D$, Starkey well fields. 
Many wetlands in the area are thought to be remnants of sinkholes and sites of active karst development (Sinclair, 1982). Watson and others (1990) identified three types of geologic settings beneath cypress wetlands at several well fields located throughout the study area based on GPR data. These wetland types included shallow depressions, shallow depressions with solution features, and relict sinkholetype systems. Their study results indicated that wetlands that formed in relict sinkhole-type systems are the most hydrologically impacted (reduced hydroperiods).

Several aspects of the karst geologic framework enhance the connection between the wetland/surficial aquifer and the underlying Upper Floridan aquifer, including (1) sinkholes or depressional piping features that have formed in the wetland bottom and extend into the clay or hardpan layer underlying the wetlands (fig. 10C); (2) similar sinkholes or depressional piping features that have formed near the perimeter of the wetland (fig. 10C) and; (3) evidence of an intermediate confining unit that contains breaches or is thin, absent, or is highly permeable (fig. 10B-D). Breaches or breaks in the sediments underlying wetlands or in the intermediate confining unit due to karst subsidence activity provide pathways for downward leakage to the underlying Upper Floridan aquifer, especially when wetlands are in areas of recharge.

Relatively deep depressions in the wetland bottom, evident in the bathymetric data for the study wetlands, were interpreted to be karst subsidence features. For example, the bathymetry of two impacted study wetlands ( $\mathrm{S}-44$ Cypress and W-16 Marsh) indicated depressions about $7 \mathrm{ft}$ below the wetland perimeter elevation (fig. $15 A-B$ ). These two wetlands had substantially shorter hydroperiods than other wetlands without these depressions. In comparison, the bathymetry of an unimpacted and minimally impacted wetland (S-68 Cypress and W-33 Cypress, respectively), revealed a shallow wetland-bottom configuration less than $2 \mathrm{ft}$ in depth (fig. 15C-D). These shallow depressional wetlands did not have a reduced hydroperiod.

One of the moderately impacted wetlands (Cypress Bridge 01) contained a number of small visible sinkholes along the wetland bottom (fig. $8 D-E$ ) that extended almost $10 \mathrm{ft}$ below the wetland perimeter elevation (fig. 16). Several small channels, which have been eroded into the wetland bottom, direct surface-water flows toward the sinkholes. These small-to-large circular depressions or subsidence features that form in wetland bottoms probably channel most of the localized recharge from the wetlands into the underlying aquifers (Metz and Sacks, 2002; Lee and others, 2009). The rate of recharge into the underlying aquifers depends upon the size, frequency of occurrence, and hydraulic conductivity of the subsidence features (Stewart and Parker, 1992).

Sinclair (1982) and Rochow (1983c) suggest that the formation of some of the recently formed subsidence features (sinkholes) in the study wetlands were influenced by groundwater withdrawals. Although sinkholes develop naturally, their high density near well fields and major agricultural areas can be explained, in part, by the large increase in groundwater withdrawals for a particular area (Sinclair, 1982; Shock and Wilson, 1996; Tihansky, 1999). For example, in May 1964, 46 sinkholes formed near the Section 21 well field, in northwestern Hillsborough County, due to an increase in well-field pumping (Sinclair, 1982) (fig. 17; location of Section 21 well field shown in fig. 1). Groundwater production at the Section 21 well field began in 1963, and withdrawal rates nearly tripled 1 year later, lowering groundwater levels more than $10 \mathrm{ft}$ and causing these sinkholes to form (Sinclair, 1982; Tihansky, 1999). Similarly, 110 sinkholes developed in an area 20 mi east of Tampa due to groundwater levels that declined about $60 \mathrm{ft}$ for several days. This large, rapid decline in groundwater levels was the result of groundwater withdrawn for frost-freeze protection during January 2010 (Southwest Florida Water Management District, 2010). A large decline in groundwater levels near well fields and agricultural lands can remove the hydraulic support of overburden sediments lying above limestone cavities, resulting in sinkhole formation (Newton, 1986).

To provide evidence of karst activity in the shallow subsurface (less than $30 \mathrm{ft}$ deep) beneath the study wetlands, GPR surveys were conducted within the perimeter of two study wetlands, Cypress Bridge 01 and W-16 Marsh. Analysis of the GPR record revealed well-defined reflectors beneath areas of the wetlands where the lateral bedding within the surficial deposits was found to be intact. In other areas of the GPR record, discontinuous and dipping reflectors indicated that the surficial deposits had been disrupted by karst subsidence. At the Cypress Bridge 01 wetland, numerous shallow swales or depressional features were found along the wetland bottom. The GPR record also shows the dipping reflectors where the surficial deposits have been disrupted. This depression in the land surface may be a piping feature that forms where surficial deposits ravel into the underlying karst limestone (fig. 18A-B). Other GPR surveys in west-central Florida have shown similar reflectors that were identified as vertical sand columns or piping features (Wilson and Garmen, 2002). In areas where these features occur, water in the surficial aquifer has the potential to leak faster to the underlying Upper Floridan aquifer than in areas where the sediments are intact.

Small filled or buried sinkholes, not evident as depressions on the land surface, were found in the GPR record for W-16 Marsh (fig. 19A-B). GPR transect $D-D^{\prime}$ at W-16 Marsh shows the surficial deposits and the intermediate confining unit overlies the irregular limestone surface of the Upper Floridan aquifer (fig. 19B). Several breaches in the clay confining unit also are evident in the record, and create the potential for increased downward leakage (fig. 19B). Other transects across $\mathrm{W}-16$ Marsh are similar to transect $D-D^{\prime}$, and show breaches in the clay confining unit beneath this wetland. 


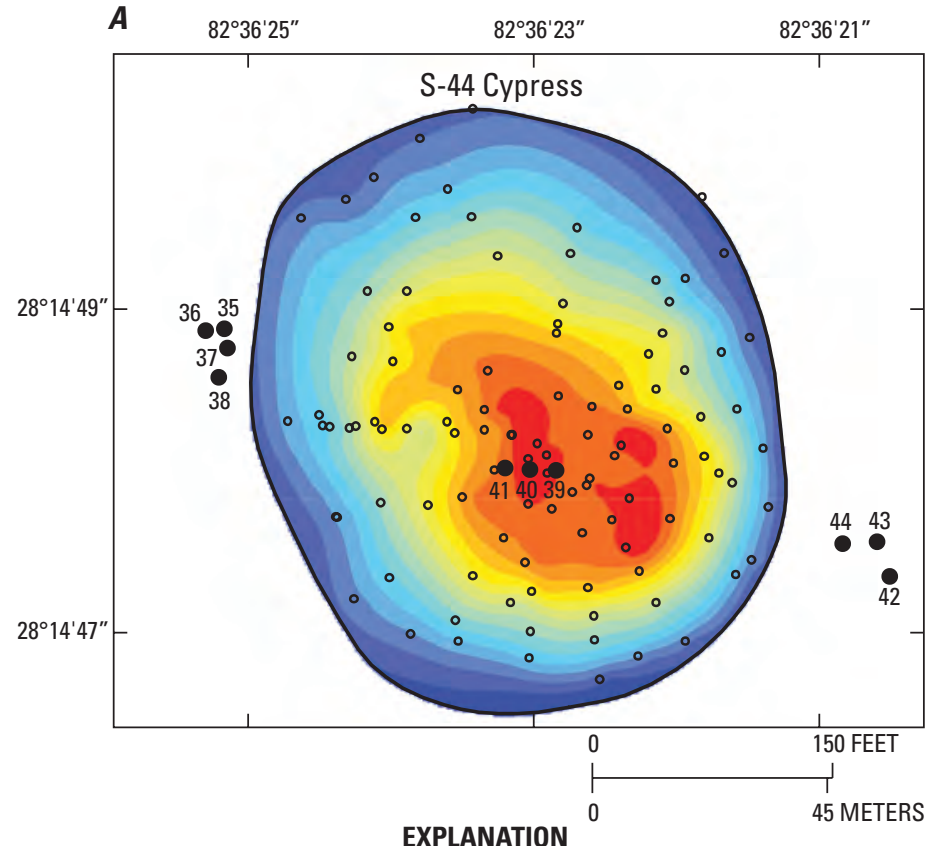

Bottom elevation, in feet above NGVD 1929

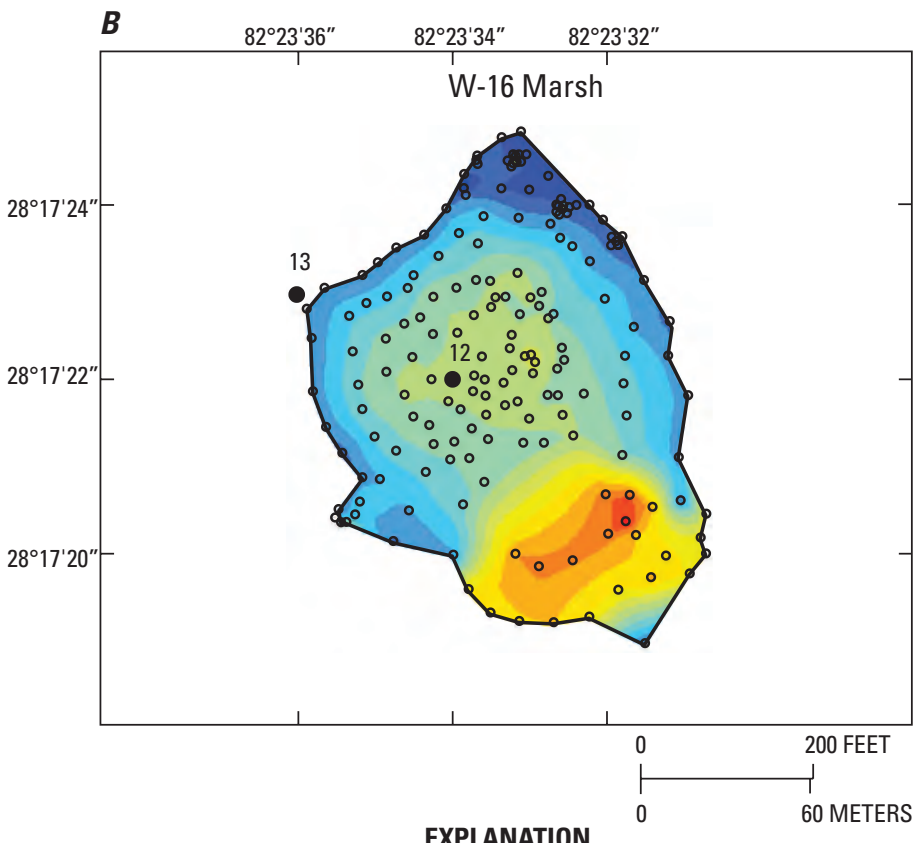

Bottom elevation, in feet above NGVD 1929

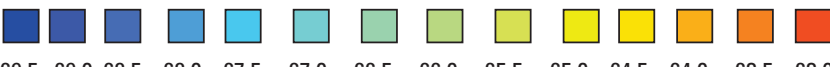

$\begin{array}{llllllllllllll}69.5 & 69.0 & 68.5 & 68.0 & 67.5 & 67.0 & 66.5 & 66.0 & 65.5 & 65.0 & 64.5 & 64.0 & 63.5 & 63.0\end{array}$

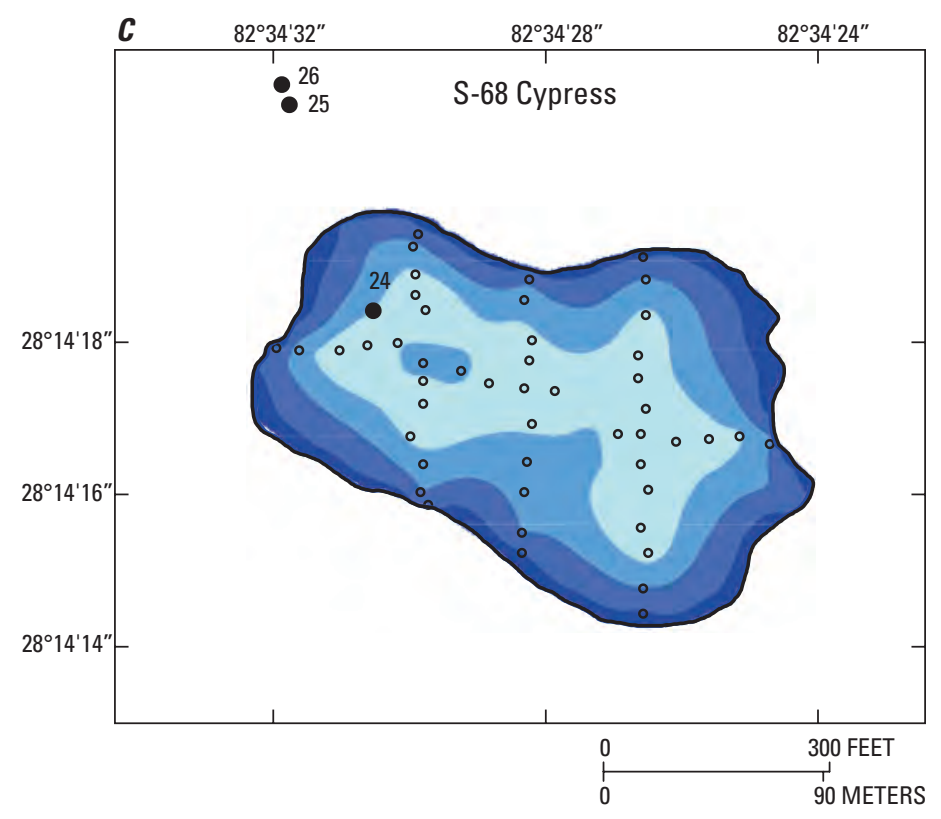

EXPLANATION

Bottom elevation, in feet above NGVD 1929

43.7

43.2

$42.7 \quad 42.2$

\section{EXPLANATION}

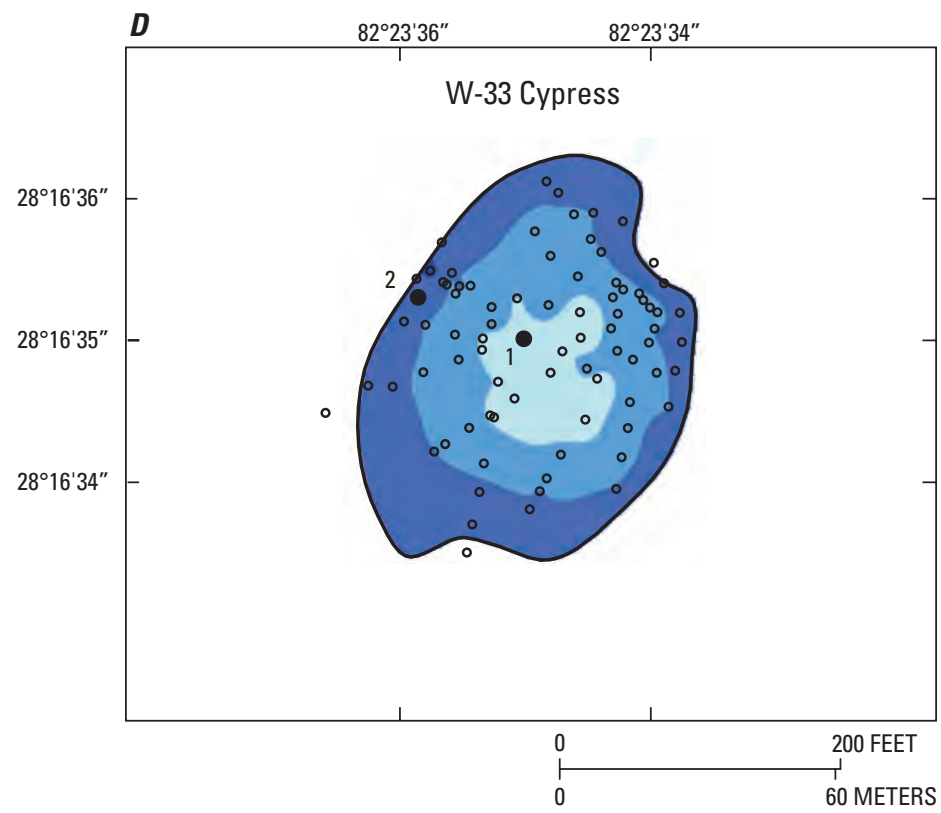

EXPLANATION

Bottom elevation, in feet above NGVD 1929

$\begin{array}{llll}70.3 & 69.8 & 69.3 & 68.8\end{array}$

○ Bathymetry survey point

${ }_{2}$ Observation well - Location and index number in table 3.

Figure 15. Bathymetry of $A-B$, severely impacted wetlands, $C$, an unimpacted wetland, and $D$, a minimally impacted wetland. 


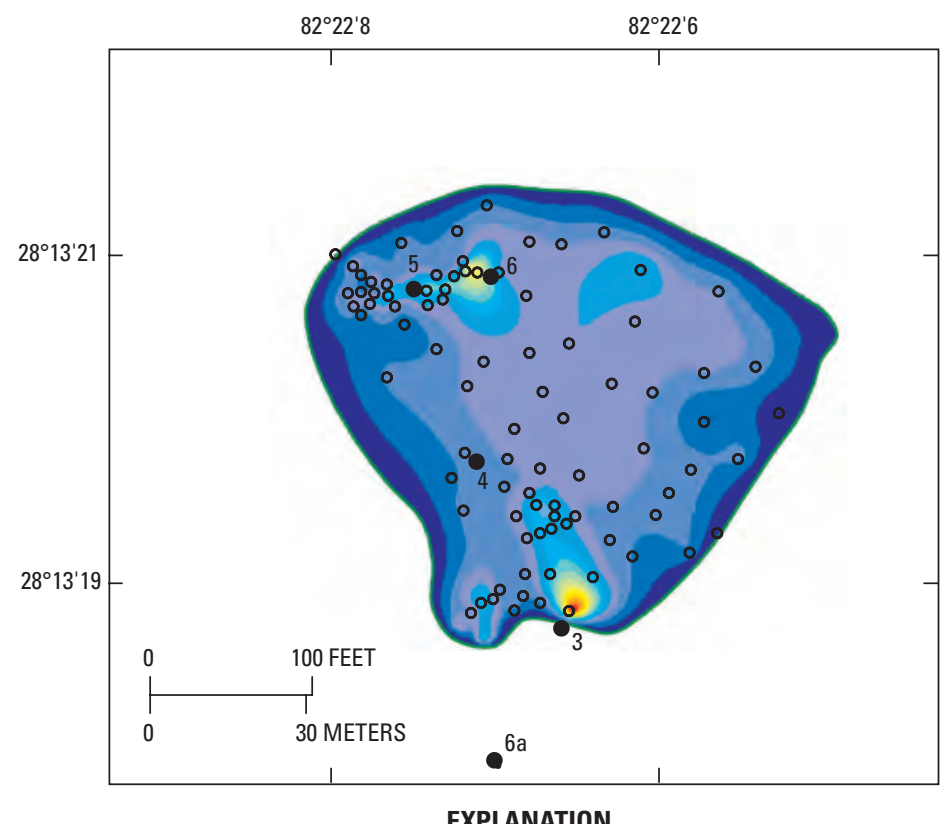

Bottom elevation, in feet above NGVD 1929

$\begin{array}{llllllllllllllll}66.0 & 65.5 & 65.0 & 64.5 & 64.0 & 63.5 & 63.0 & 62.5 & 62.0 & 61.5 & 61.0 & 60.5 & 60.0 & 59.5 & 59.0 & 58.5\end{array}$

- Bathymetry survey point 3 Data site-Location and index number in table 3.

Figure 16. Bathymetry of the Cypress Bridge 01 wetland.

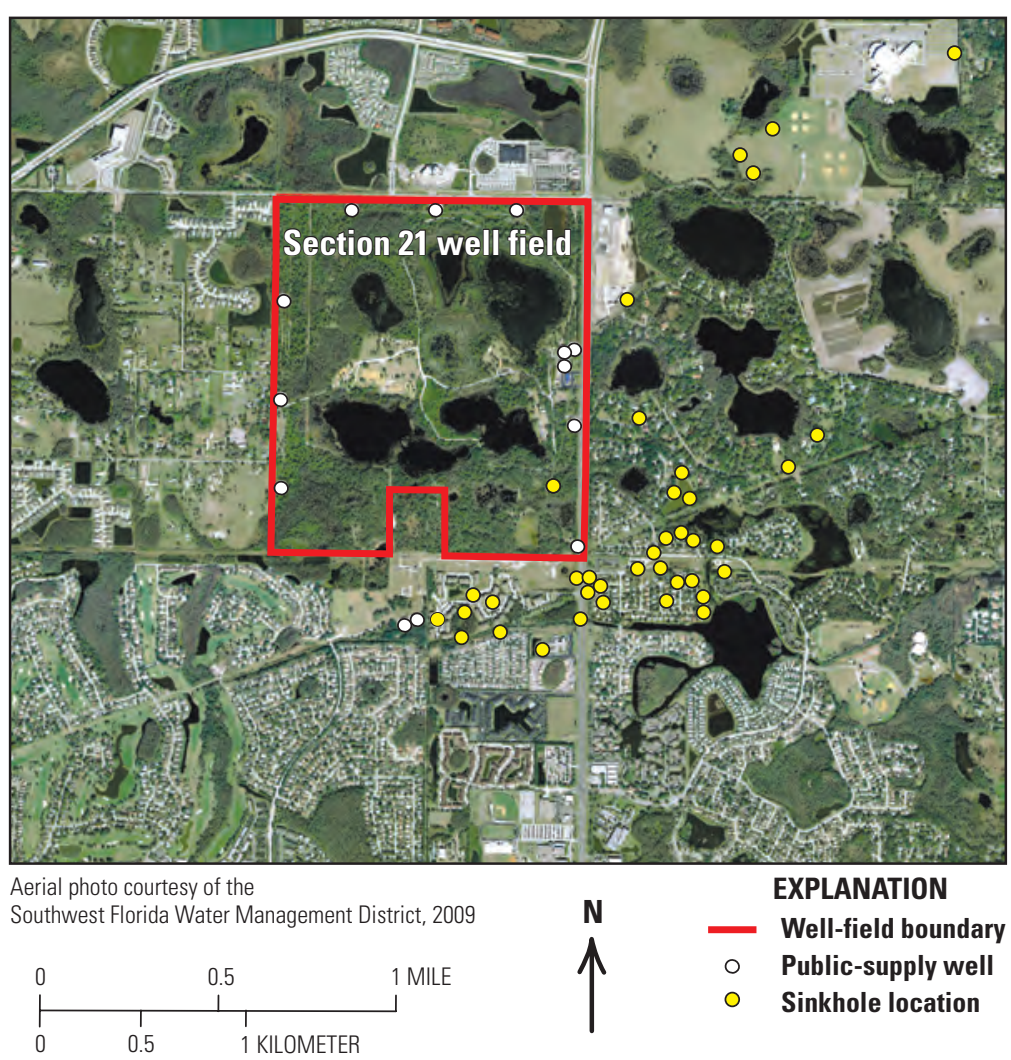

Figure 17. Aerial photograph showing the location of sinkholes that formed in and around the Section 21 well field due to groundwater withdrawals. Modified from Sinclair (1974) and Tihansky (1999). 
$\boldsymbol{A}$

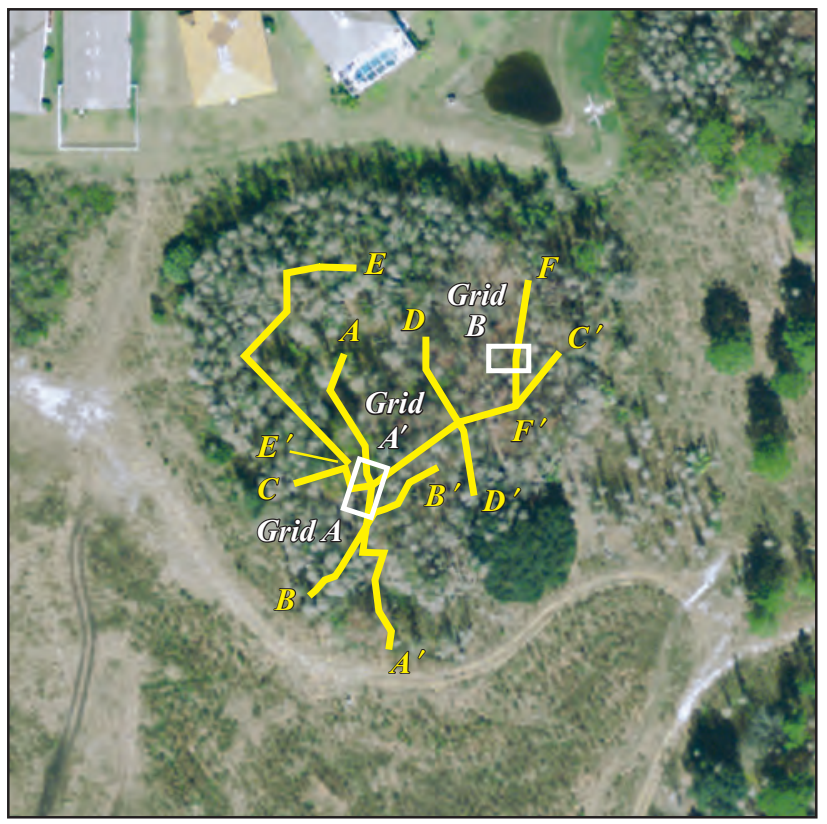

Aerial photo courtesy of the Southwest Florida Water Management District, 2009

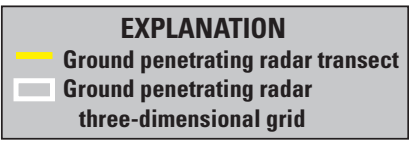

B

GRID $A$

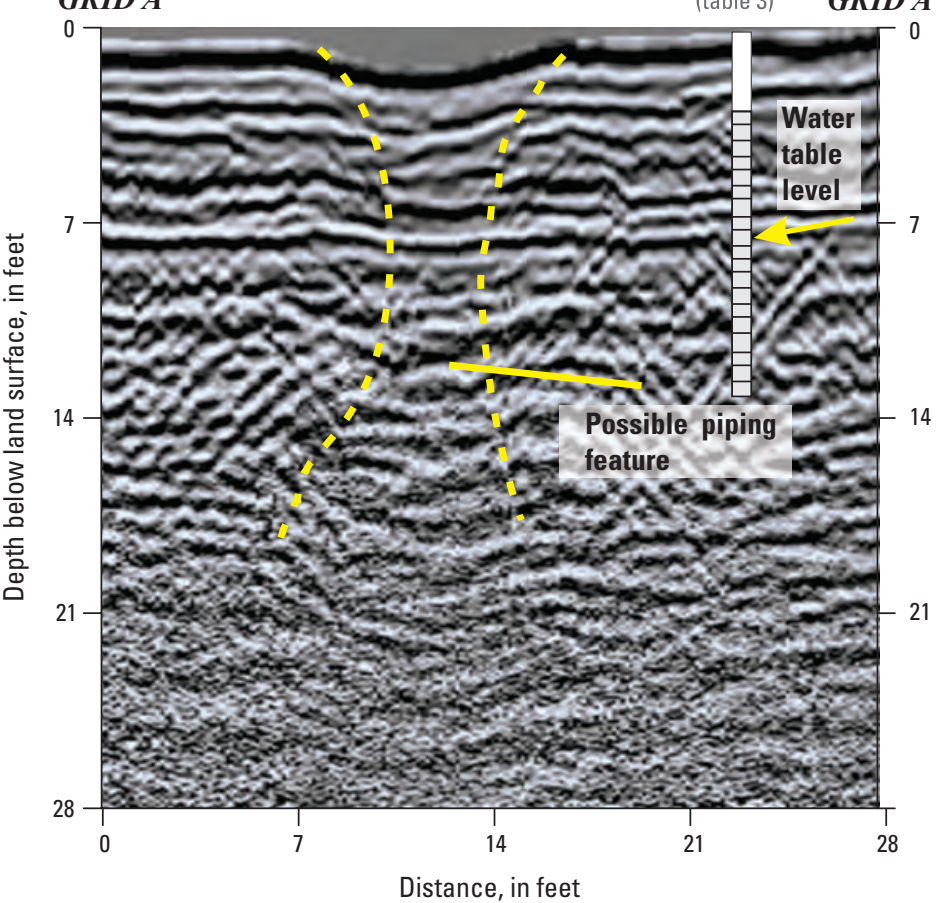

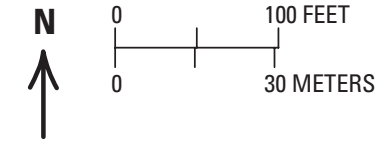

30 METERS

CYB-01 13 foot well (table 3) GRID $\boldsymbol{A}^{\prime}$ stance, in feet
Figure 18. A, Aerial photograph showing the location of ground-penetrating radar (GPR) transect lines, and $B$, geophysical profile $A-A^{\prime}$ with interpreted geologic features below Cypress Bridge 01 at the Cypress Bridge well field.
Results of water-level analyses performed on the study wetlands yield insight into the degree of confinement or hydraulic connection between the wetland/surficial aquifer and the Upper Floridan aquifer. Water-level differences between the aquifers may indicate the localized nature of the confining-unit sediments or the influence of karst subsidence. For example, where the confining unit is thin, relatively permeable, breached by sinkholes, or contains sand-filled piping features, these characteristics will enhance the downward movement of water from the wetland/surficial aquifer to the Upper Floridan aquifer, resulting in a small water-level difference between the two aquifers. Conversely, a relatively large water-level difference between the aquifers indicates potentially greater confinement of the Upper Floridan aquifer beneath the wetland (fig. 20). Large water-level differences can be used as evidence of confinement in areas where there are pumping stresses. The strengths of linear relations $\left(\mathrm{r}^{2}\right.$ values; with 1.0 being the most significant) were used to help evaluate the vertical head relations between the wetland/ surficial aquifer and the Upper Floridan aquifer at the study wetlands (table 4). An $\mathrm{r}^{2}$ value closer to 1 generally indicates a higher degree of hydraulic connection between the wetland/ surficial aquifer and the Upper Floridan aquifer.

Box plots of water-level data collected during this study (January 2007 to March 2008) indicate that the median daily average water-level difference between the wetland/surficial aquifer and the Upper Floridan aquifer varied from about 1 to $16 \mathrm{ft}$ among eight of the study wetlands (fig. 20). Water-level differences indicate that the permeability of the underlying sediments and the presence of karst features are a dominant control on potential for vertical flow. For example, the median water-level difference between the wetland/surficial aquifer and the Upper Floridan aquifer for the study period at the minimally impacted W-33 Cypress wetland was about $16 \mathrm{ft}$, reflecting the integrity of the intermediate confining unit between these two aquifers at this site. Geologic data for this wetland (fig. 14A) indicate high clay content within the upper sediment layers and the intermediate confining unit that retard downward leakage to the Upper Floridan aquifer. Likewise, the linear relation between the wetland/surficial aquifer and Upper Floridan aquifer levels at the W-33 Cypress wetland was relatively poor $\left(r^{2}=0.49\right.$, table 4$)$, confirming the weak hydraulic connection between the hydrogeologic units. W-33 Cypress is classified as minimally impacted, and the integrity of the underlying clay confining unit is an important factor in controlling the hydrologic response of this wetland.

Two severely impacted wetlands, (S-44 Cypress and W-16 Marsh) and a moderately impacted wetland (Cypress Bridge 01) all had a relatively small median water-level difference between the wetland/surficial aquifer and the Upper Floridan aquifer (0.90, 2, and $1 \mathrm{ft}$, respectively; fig. 20). All three of these wetlands have either karst subsidence or sinkholes in the wetland bottom that were exacerbated by large groundwater withdrawals. Linear relations between the wetland/surficial aquifer and Upper Floridan aquifer water 


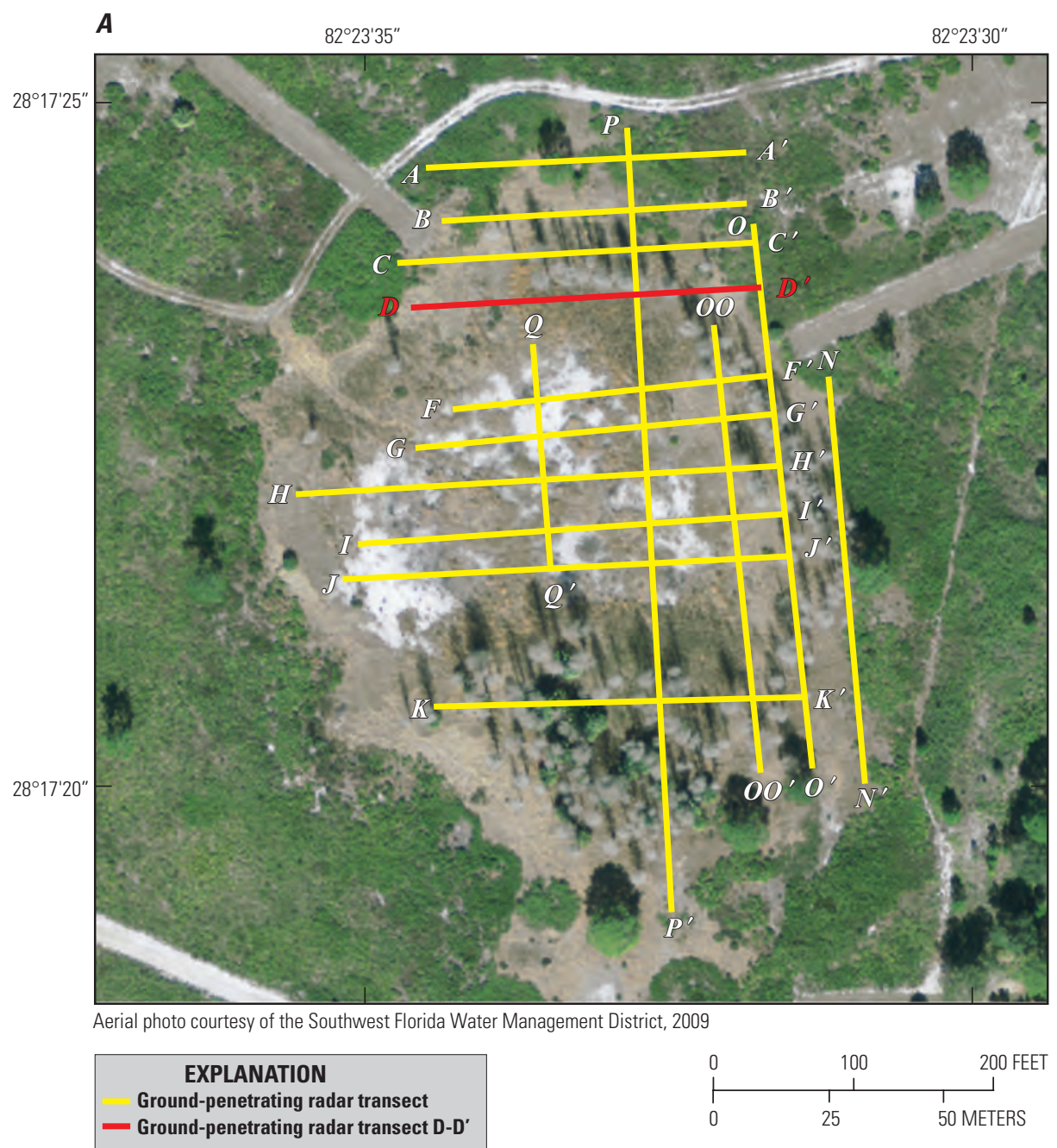

$B$

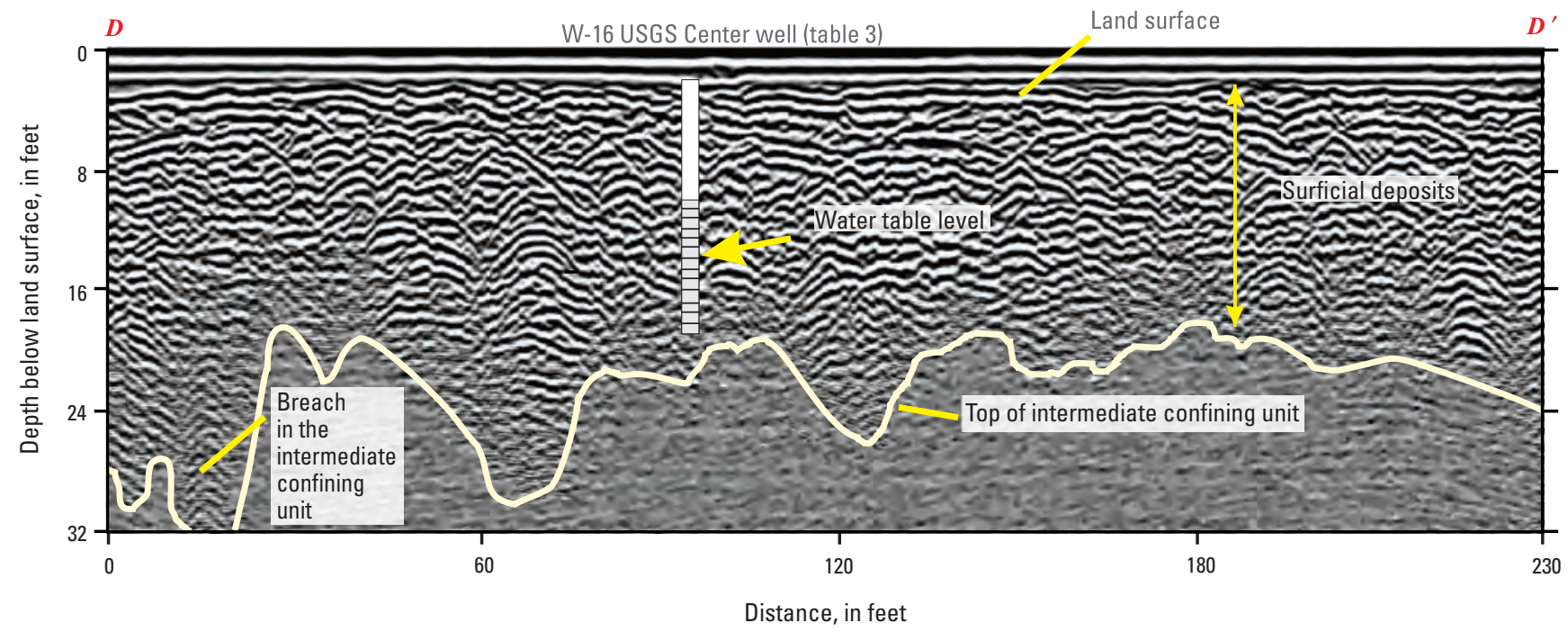

Figure 19. A, Aerial photograph showing the location of ground-penetrating radar (GPR) transect lines, and $B$, geophysical profile $D-D^{\prime}$ with interpreted geologic features below W-16 Marsh at the Cypress Creek well field. 


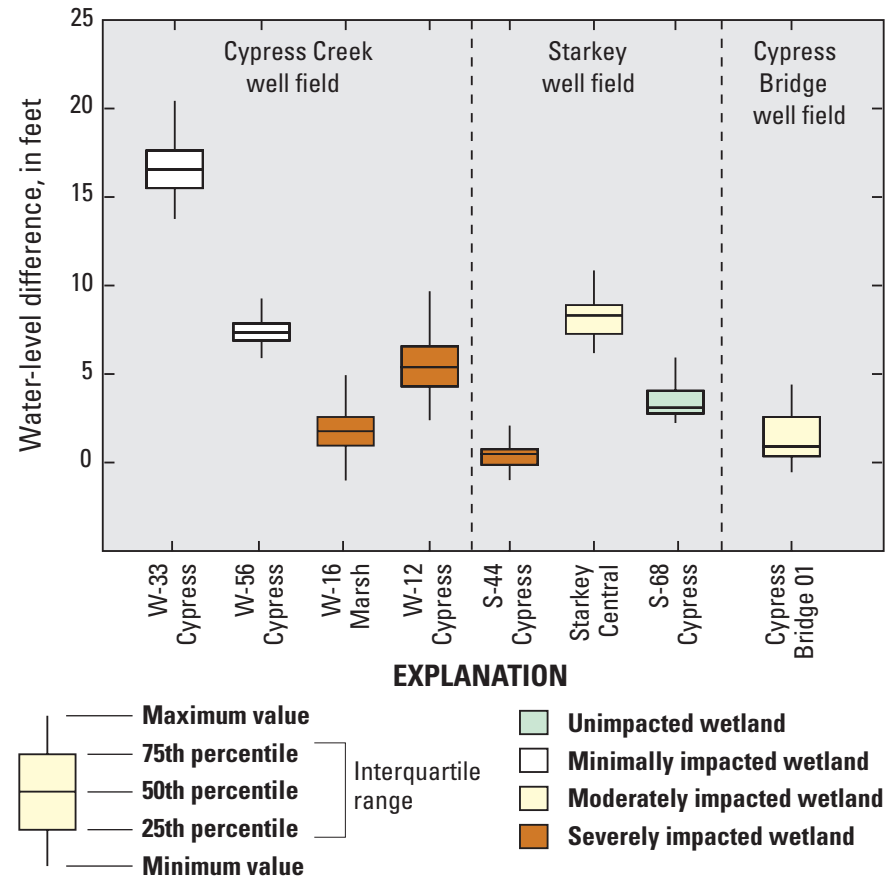

Figure 20. Box plots showing water-level differences between the wetland/surficial aquifer and Upper Floridan aquifer for the study wetlands, 2007-08.

Table 4. Relation between surficial and Upper Floridan aquifer levels at the study wetlands.

$\left[\mathrm{r}^{2}\right.$, coefficient of determination between daily surficial and Upper Floridan aquifer levels for December 2007- March 2008; all regressions significant to alpha level of 0.05; S, Starkey; CC, Cypress Creek; CB, Cypress Bridge]

\begin{tabular}{clccl} 
Well & Wetland name & $\begin{array}{c}\text { Wells } \\
\text { used for } \\
\text { comparison }\end{array}$ & $\mathbf{r}^{2}$ & Classification \\
\hline S & S-68 Cypress & 26,27 & 0.51 & Unimpacted \\
S & Starkey Central & 28,32 & 0.73 & Moderately impacted \\
\hline S & S-44 Cypress & 36,41 & 0.83 & Severely impacted \\
CC & W-33 Cypress & 7,9 & 0.49 & Minimally impacted \\
\hline CC & W-56 Cypress & 21,23 & 0.75 & Minimally impacted \\
CC & W-12 Cypress & 16,19 & 0.60 & Severely impacted \\
\hline CC & W-16 Marsh & 14,19 & 0.80 & Severely impacted \\
CB & Cypress Bridge 01 & 1,5 & 0.75 & Moderately impacted \\
\hline
\end{tabular}

${ }^{1}$ Well index numbers are shown in table 3 . levels for S-44 Cypress, W-16 Marsh, and Cypress Bridge 01 wetlands indicate that much of the variability in water levels between the aquifers is statistically related $\left(\mathrm{r}^{2}=0.83,0.80\right.$, and 0.75 , respectively; table 4 ). This analysis indicates that when karst subsidence activity disrupts the confining layers beneath a wetland, a connection is created between the wetland and the underlying aquifers, which reduces the water-level differences between them.

\section{Potentiometric Surface of the Upper Floridan Aquifer}

A number of groundwater modeling studies have documented that groundwater withdrawals from the Upper Floridan aquifer at the Northern Tampa Bay well fields have lowered the potentiometric surface within and surrounding the well fields (Hutchinson, 1984; Southwest Florida Water Management District, 1996). Groundwater modeling results in Hutchinson (1984) indicate that a large part of the water that replaces this groundwater withdrawal comes from downward leakage from the surficial aquifer and wetlands in these well field areas. Consequently, this downward leakage has resulted in reduced hydroperiods for some wetlands in these areas, and in some cases, has adversely affected wetland health (Sinclair, 1982; Rochow, 1998; Lee and others, 2009).

\section{Historical Trends in Groundwater Levels}

Examining historical groundwater levels beneath the study wetlands provides an understanding of how changing water-level conditions can impact wetlands. A number of Northern Tampa Bay area well fields came online during the 1970s, including Starkey and Cypress Creek well fields, where production began during 1974 and 1976, respectively. The long-term hydrographs (ranging from 1949 to 2010) from wells tapping the Upper Floridan aquifer and surficial aquifer within and surrounding the study well fields show the variability of water levels influenced by groundwater withdrawals and climatic conditions (figs. 21 and $22 A-F$; well locations shown in fig. 13).

The distance-weighted least squares method (McClain, 1974) was used as a smoothing and interpolation approximation technique to reveal the overall pattern or trend in the long-term surficial and Upper Floridan aquifer levels within and surrounding Cypress Creek and Starkey well fields. For some of the wells examined, the highest aquifer water levels occurred prior to well-field production, but aquifer levels were also high in 1998 and 2004 (figs. 21 and $22 A-F$ ), when several large rain events occurred (fig. 2). Some of the lowest groundwater levels occurred during a severe drought in 2000 (Verdi and others, 2006), when groundwater withdrawals were highest in the Northern Tampa Bay area (fig. 5A). 

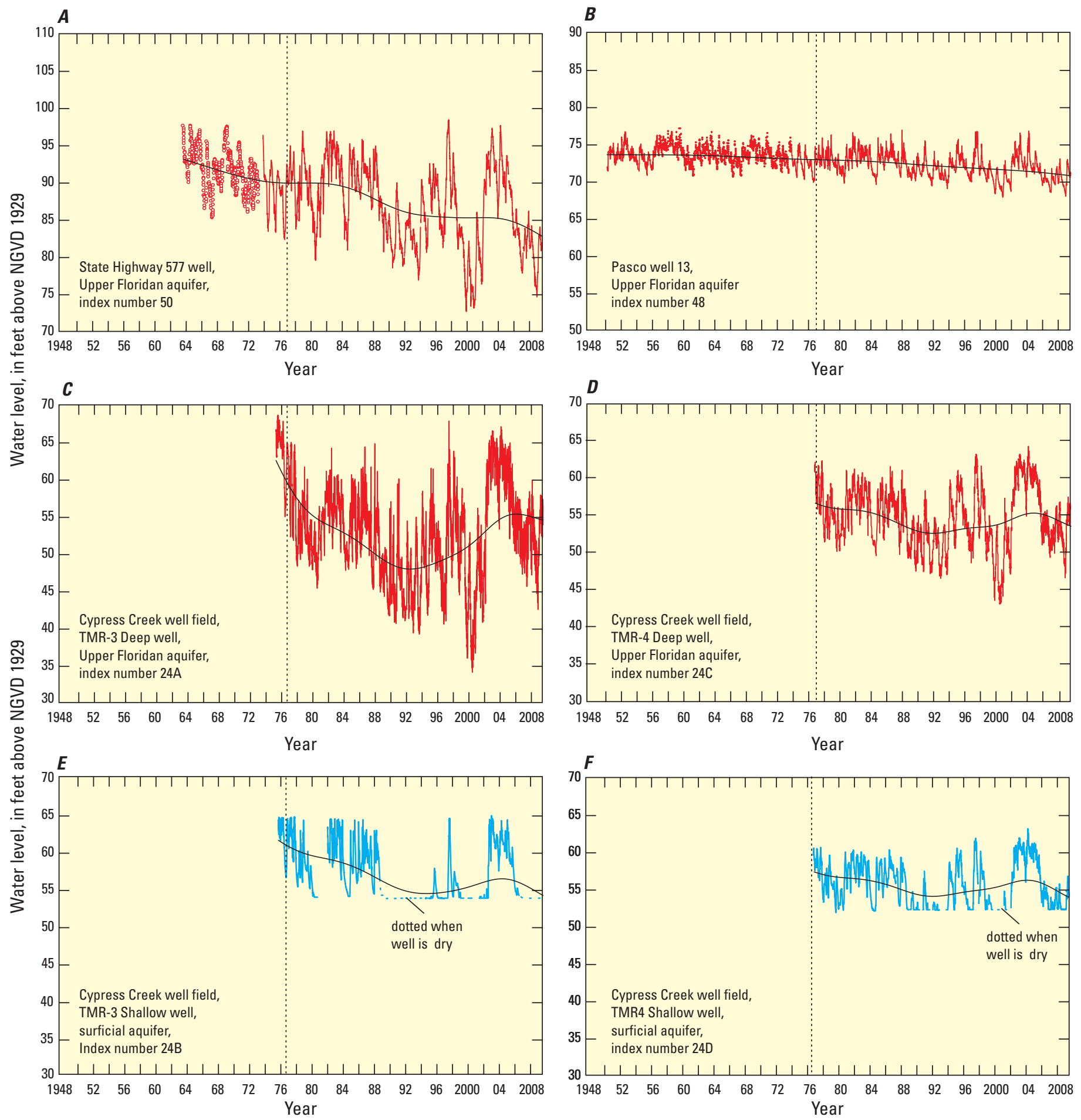

EXPLANATION

Beginning of well-field production

Distance-weighted least squares fitting (McLain, 1974)

Upper Floridan aquifer

Surficial aquifer

Figure 21. Hydrographs showing long-term water levels for the Upper Floridan aquifer and surficial aquifer at the Cypress Creek well field and surrounding areas. Well construction data and index number are shown in table 3 and location of wells are shown in figure 13. 

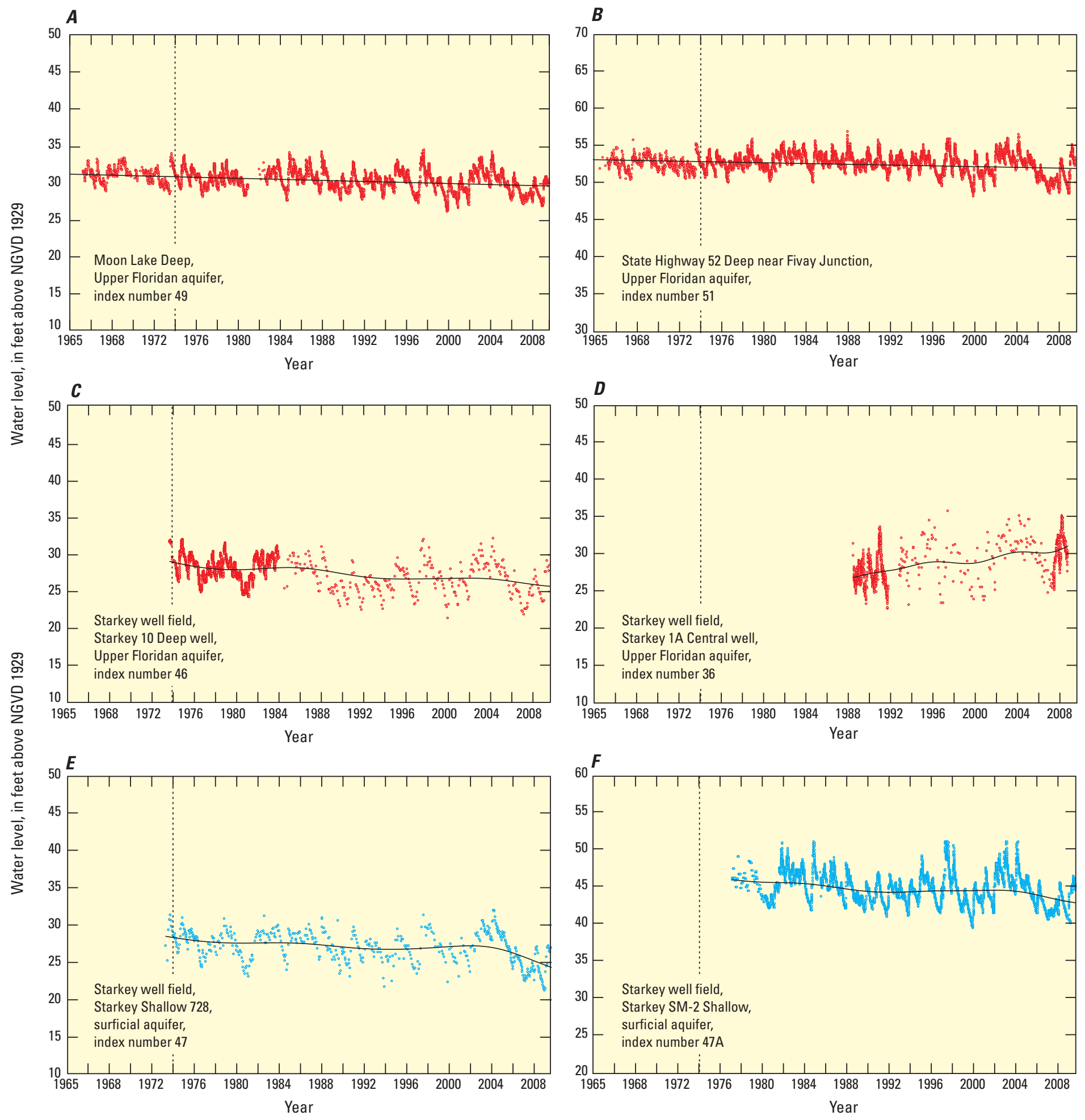

\section{EXPLANATION}

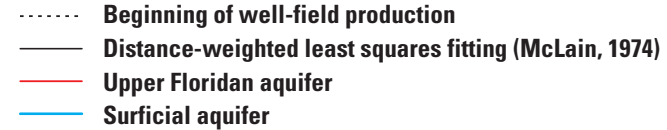

Figure 22. Hydrographs showing long-term water levels for the Upper Floridan aquifer and surficial aquifer at the Starkey well field and surrounding areas. Well construction data and index number are shown in table 3 and location of wells are shown in figure 13. 
Long-term water-level data for the Upper Floridan aquifer wells to the east (State Highway 577 well; fig. 21A; well location shown in fig. 13) and southwest (Pasco well 13; fig. 21B; well location shown in fig. 13) of Cypress Creek well field show varying degrees of fluctuation, which are attributed to the level of confinement overlying the Upper Floridan aquifer and localized groundwater withdrawals in that area (fig. 14). The intermediate confining unit overlying the Upper Floridan aquifer is thicker to the east of the well field (Buono and others, 1979), resulting in a greater amplitude of water-level fluctuations at State Highway 577 well than at Pasco well 13. Water-level trends for State Highway 577 well indicate about a 10-ft decline from 1965 to 2009, whereas water-level trends for Pasco well 13 indicate about a 2-ft decline from 1949 to 2009 (fig. 21A-B).

Groundwater level fluctuations resulting from Upper Floridan aquifer withdrawals in the Cypress Creek well field are greatest near the TMR-3 Deep well (fig. 21C). In addition, the confining layer overlying the Upper Floridan aquifer is thicker at this location than in areas southwest of the well field, which also contributes to the attenuation of these levels (Buono and others, 1979). Long-term water-level trends for TMR-3 Deep shows a descending trend from 1975 to the early-1990s and an ascending trend during the high rainfall periods of 1998 and 2003-05 (fig. 21C). The ascending trend during 2003-05 also coincided with the reductions in groundwater withdrawals at Cypress Creek well field, which began in 2003 (fig. 5C). The water-level trend was relatively flat during 2005-06, and declined slightly during 2007-09. This most recent decline was caused by a return to a rainfall deficit and increased groundwater withdrawals in the well field (figs. $2 \mathrm{~A}$ and 5C). Water-level trends for the TMR-4 Deep well, which also taps the Upper Floridan aquifer, are flatter than those at TMR-3 Deep, probably because TMR-4 Deep is farther from the pumping center (fig. $21 D$ and fig 7).

Surficial aquifer levels are influenced by rainfall, seasonal evapotranspiration, and by leakage to the Upper Floridan aquifer. Long-term water-level trends for the surficial aquifer (TMR-3 Shallow and TMR-4 Shallow wells) at the Cypress Creek well field include a general decline from 1976 to the late-1980s, an increase during late 1990s and 2003-04, and a decline after 2005 (fig. $21 E-F$ ). The largest declines in water levels for TMR-3 Shallow usually occurred during dry periods when recharge to the surficial aquifer was minimal or absent (fig. 2), and when the need for groundwater supply from the Upper Floridan aquifer increased. TMR-3 Shallow frequently was dry during 1979-2009, with the longest dry period being 1989-95. The increased stresses on the Upper Floridan aquifer, which induced downward leakage from the surficial aquifer during these extended dry periods, likely caused adverse effects to many wetlands in this large drawdown area (app. 3A). The TMR-4 Shallow well also went dry several times, but not as frequently as TMR-3 Shallow most likely because TMR-4 Shallow is deeper than TMR-3 Shallow and farther from the large drawdown area in the Upper Floridan aquifer (app. 3A).
Long-term water-level data for two Upper Floridan aquifer wells to the northeast and the north (fig. $22 A-B$ ) of Starkey well field show similar water-level fluctuations and long-term trends, including a small $(2 \mathrm{ft})$ overall decline from 1965 to 2009 for both wells. Water-level fluctuations were smaller in Upper Floridan aquifer wells within Starkey well field (fig. $22 C-D$ ) compared to those at the Cypress Creek well field (fig. $21 C-D$ ). There are several reasons for the attenuation of water-level fluctuations at Starkey well field, including (1) the smaller volume of water pumped from Starkey well field; (2) the greater spacing of production wells over a larger area, which influences the size and shape of the cone of depression; and (3) less confinement between the wetland/surficial aquifer and the Upper Floridan aquifer at Starkey well field.

Long-term water-level trends for Starkey 10 Deep well (Upper Floridan aquifer), located west of the pumping center at Starkey well field, indicates a small $(2 \mathrm{ft})$ descending trend from 1974 to 2009 (fig. 22C). Long-term water-level trends for Starkey 1A Central well, located in the center of Starkey well field, are based on a shorter period of record (1988-2009) and generally shows an ascending trend during this period (fig. 22D). This ascending trend in Upper Floridan aquifer levels at this well is the result of above average rainfall conditions that existed in the Starkey well field area during 2002, 2004, and 2009 (fig. 2A) and the reductions in groundwater withdrawals (from 12 to $4 \mathrm{Mgal} / \mathrm{d}$ ), that were initiated in December 2007 (fig. 5C). As a result, the maximum water levels for the 1988-2009 period of record for this well occurred in 2009 (fig. 22D).

Water-level trends for two surficial aquifer wells at Starkey well field remained relatively flat for most of the analysis period (fig. 22E-F), although a slight descending trend was observed after 2005 due to below-average rainfall during 2005-08 (fig. 2A). A reduction in groundwater withdrawals from the Upper Floridan aquifer was initiated in December 2007 at Starkey well field, but this reduction is not yet discernable in the trends for the surficial aquifer because of drought conditions during 2005-08.

\section{Potentiometric Surface Elevations before and after Reductions in Groundwater Withdrawals}

To determine the hydrologic condition of a wetland, it is important to know the vertical position of the potentiometric surface of the Upper Floridan aquifer relative to the wetland bottom. When the potentiometric surface of the Upper Floridan aquifer is at or near land surface, it limits the downward leakage potential and helps sustain the water needed for wetland functions. The leakage potential increases as the potentiometric surface of the Upper Floridan aquifer recedes below the wetland bottom, and, if sufficiently large, this decline can substantially reduce the wetland hydro- 
period. The hydrologic condition of the wetland is further compromised (1) when the geology surrounding or underlying the wetland is influenced by sinkhole development, such as breaches in the intermediate confining unit, or (2) where permeable surficial sediments underlie the wetland.

Elevation-difference maps based on potentiometric surface maps and LIDAR data were created to spatially define the potentiometric surface of the Upper Floridan aquifer relative to the wetland-bottom elevation prior to any groundwater development at Starkey and Cypress Creek well fields (fig. 23A-B). Areas where the potentiometric surface was above or at land surface were considered discharge areas having upward flow, and areas where the potentiometric surface of the Upper Floridan aquifer was below land surface were considered recharge areas having downward flow.

Elevation-difference maps using data collected prior to groundwater development at the Cypress Creek and Starkey well fields show large areas of groundwater discharge within and surrounding the well fields. Most of the study wetlands (except Starkey Central and W-33 Cypress wetlands) were located in discharge areas. Most of the discharge areas in the Starkey well field were associated with low lying areas, including the Pithlachascotee River and its tributaries north of the well field, Cross Cypress Branch near the center, Anclote River to the south, and the large headwater area of the Anclote River east of the well field (fig. 23A). At Cypress Creek well field, the discharge areas were associated with low-lying areas of the Big Cypress Swamp and the floodplain of Cypress Creek, both of which constitute a large part of the well field (fig. 23B). Maps of areal discharge and recharge by Aucott (1988) and Vecchioli and others (1990), also show parts of Starkey and Cypress Creek well fields identified as discharge areas. In these areas, the potentiometric surface of the Upper Floridan aquifer ranges from about 0 to $5 \mathrm{ft}$ above land surface, which helps limit the downward leakage potential from the wetlands.

Elevation-difference maps also were created to show the current and seasonal changes in the potentiometric surface of the Upper Floridan aquifer relative to land-surface elevations (figs. 24 and 25). A comparison of these maps to the predevelopment maps in figure 23 indicates a large shift from mostly discharge conditions prior to groundwater development, to mostly recharge conditions during 2008-09. During September 2008, however, several discharge areas were present at both well fields. At Starkey well field, the discharge areas were associated with a narrow band around the channels of the Pithlachascotee River, Cross Cypress Branch, and Anclote River (fig. 24A). At Cypress Creek well field, a small discharge area associated with Cypress Creek was present along the southwestern boundary of the well field (fig. 25A). During May 2009, areas of discharge were reduced further at both well fields compared to September 2008 (figs. $24 B$ and 25B).

To help alleviate the decline in wetland water levels, reduced groundwater withdrawals from the Upper Floridan aquifer were implemented at Starkey and Cypress Creek well fields at the end of 2007 and 2002, respectively. The reduction in groundwater withdrawals varied over time at each well field. At Cypress Creek well field, for example, groundwater withdrawals averaged about $30 \mathrm{Mgal} / \mathrm{d}$ during 1978-2000, declined to $9 \mathrm{Mgal} / \mathrm{d}$ during 2003, then increased to an average of about $16 \mathrm{Mgal} / \mathrm{d}$ during 2004-09 (fig. 5C). At Starkey well field, the reduction in groundwater withdrawals was more immediate; after an interconnector pipeline was completed between well fields in late 2007, the pumpage was reduced from an average of about $12 \mathrm{Mgal} / \mathrm{d}$ during 1988-2007 to $4 \mathrm{Mgal} / \mathrm{d}$ after November 2007 (fig. 5C).

Box plots were used to assess the historical and current levels of the Upper Floridan aquifer relative to the study wetland-bottom elevations prior to and after the reductions in groundwater withdrawals at the Starkey and Cypress Creek well fields. The box plots for the study wetlands (fig. 26) were constructed to show the daily average elevation difference between the lowest point along the wetland bottom and the potentiometric surface of the Upper Floridan aquifer prior to and after the reductions in groundwater withdrawals at the two well fields. The wetland bottom elevation is used as a surrogate for the wetland water level to allow comparisons between surface and groundwater levels even when wetlands were dry. Because wetlands are typically shallow, the elevation difference computed using the wetland bottom is generally only several feet less than the water level derived from the wetland stage when the wetland is flooded (Lee and others, 2009).

The elevation-difference analysis period for the wetlands prior to the reduction in groundwater withdrawals included January 1989 to December 2007 and January 1989 to December 2002 for Starkey and Cypress Creek well fields, respectively. The elevation-difference analysis period for the wetlands after the reduction in groundwater withdrawals included January 2008 to March 2010 and January 2003 to May 2009 for Starkey and Cypress Creek well fields, respectively.

A general comparison between the two well fields prior to and after the reduction in groundwater withdrawals indicates that the median potentiometric surface elevation of the Upper Floridan aquifer was generally closer to the wetlandbottom elevation for wetlands at Starkey well field compared to wetlands at Cypress Creek well field (fig. 26). In addition, the elevation range of the potentiometric surface of the Upper Floridan aquifer was generally far less below wetlands at Starkey well field than at Cypress Creek well field.

Prior to the reduction in groundwater withdrawals at Starkey well field, the median potentiometric surface elevation ranged from near land surface (S-44 Cypress and Grass Prairie) to about $15 \mathrm{ft}$ below the wetland-bottom elevation (Starkey Central). The potentiometric surface was occasionally above land surface at Grass Prairie and S-44 Cypress, indicating discharge conditions (fig. 26).

The S-44 Cypress wetland bottom contained a number of karst subsidence features that had lowered the natural depth of the cypress wetland in several areas. Undisturbed cypress wetlands usually have an average maximum depth of about 


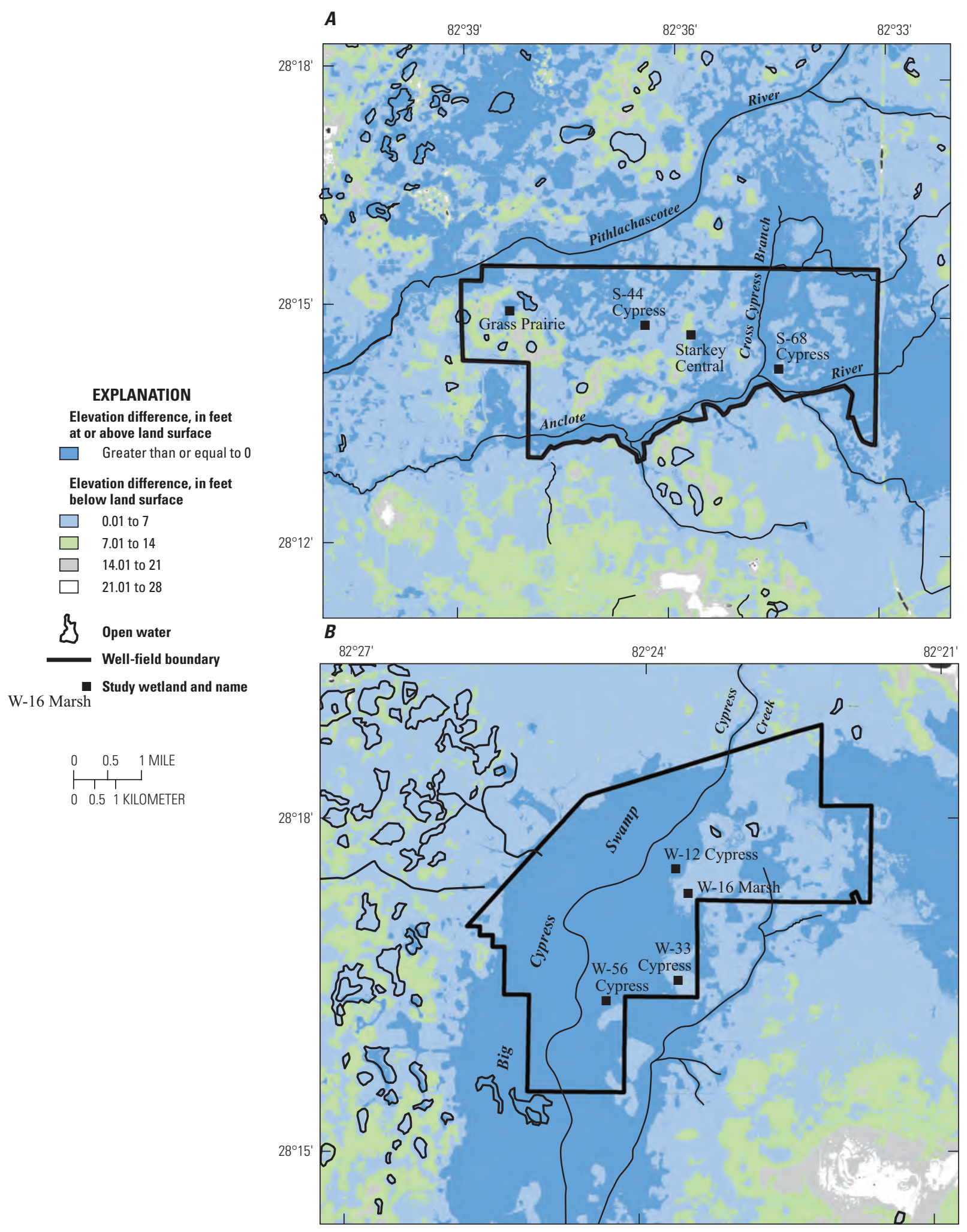

Figure 23. Elevation difference between land surface and the potentiometric surface of the Upper Floridan aquifer at the $A$, Starkey well field and the $B$, Cypress Creek well field. Elevation difference map, in feet, based on subtracting the potentiometric surface of the Upper Floridan aquifer prior to development (Johnston and others, 1980) from land-surface elevation data (2005 LIDAR data) provided by the Southwest Florida Water Management District. 


\section{A. September 2008}

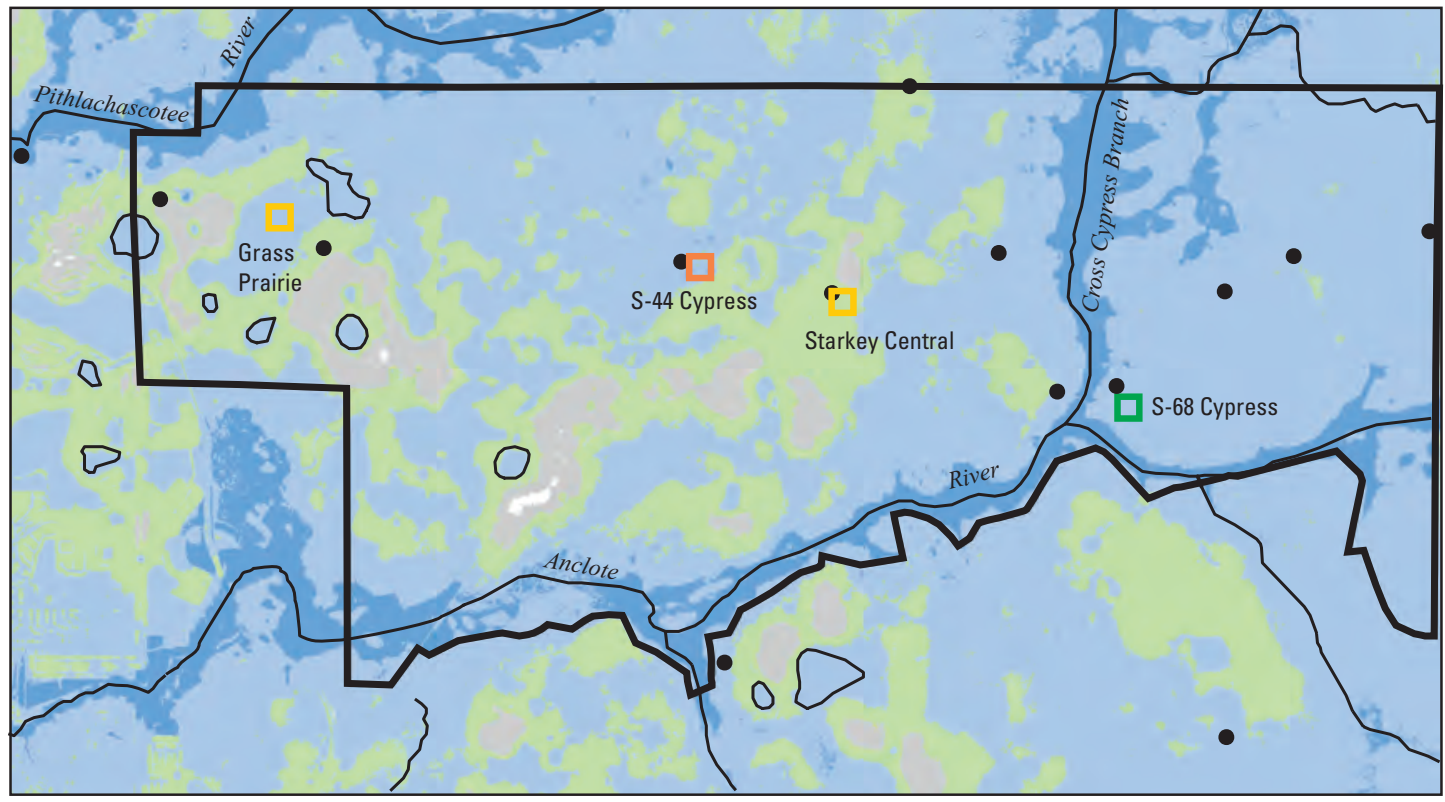

B. May 2009

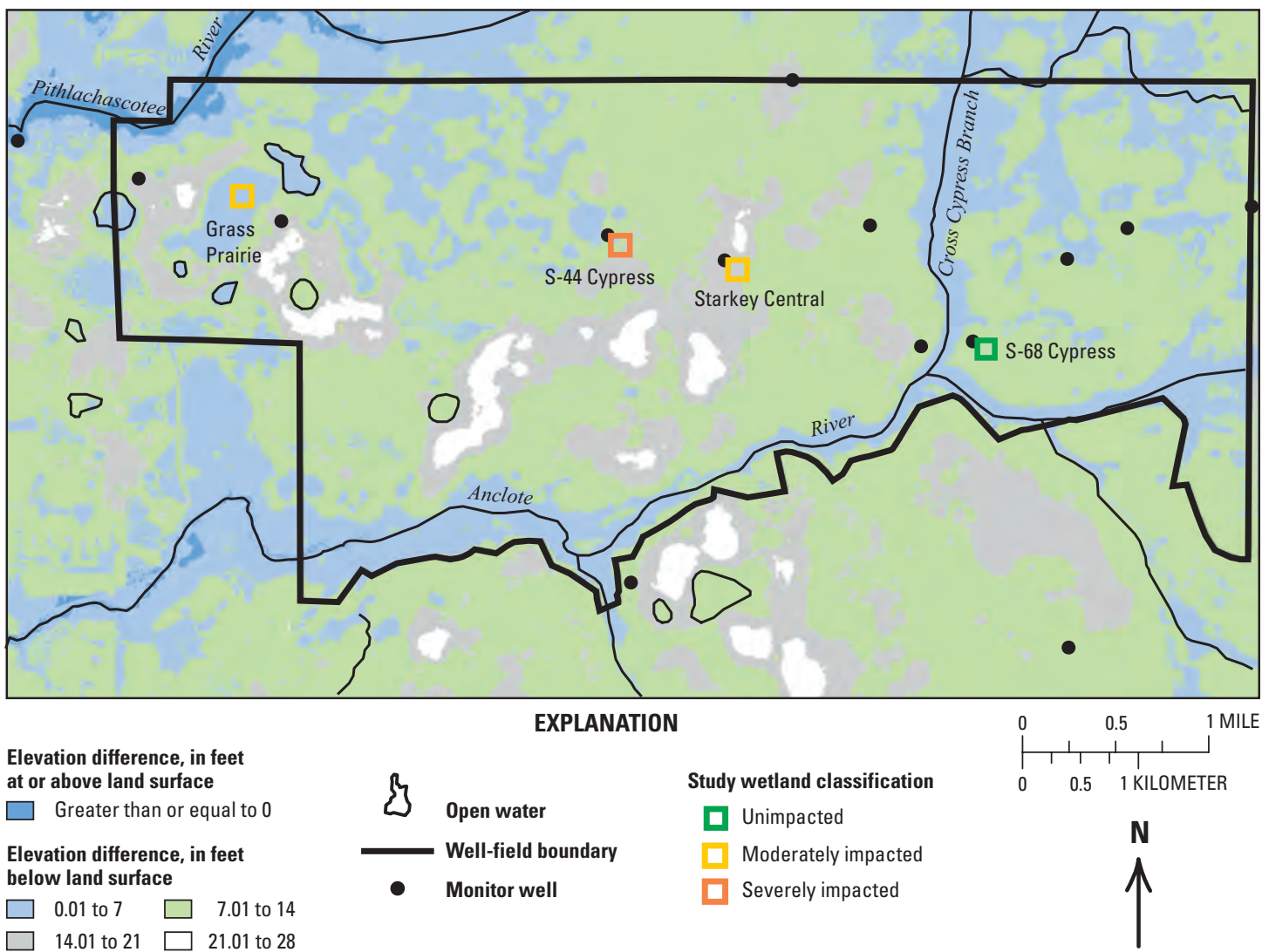

Figure 24. Elevation difference between land surface and the potentiometric surface of the Upper Floridan aquifer during $A$, September 2008, and $B$, May 2009 at the Starkey well field. Elevation difference map, in feet, based on subtracting the potentiometric surface of the Upper Floridan aquifer during September 2008 and May 2009 from land-surface elevation data (2005 LIDAR data) provided by the Southwest Florida Water Management District. 


\section{EXPLANATION}

Elevation difference, in feet at or above land surface

Greater than or equal to 0

Elevation difference, in feet below land surface

$\square \quad 0.01$ to 7

7.01 to 14

14.01 to 21

21.01 to 28

ßpen water

Well-field boundary

- Monitor well

Study wetland classification

- Minimally impacted

Severely impacted
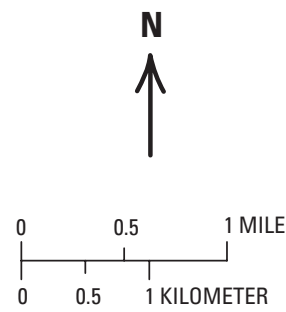

A. September 2008

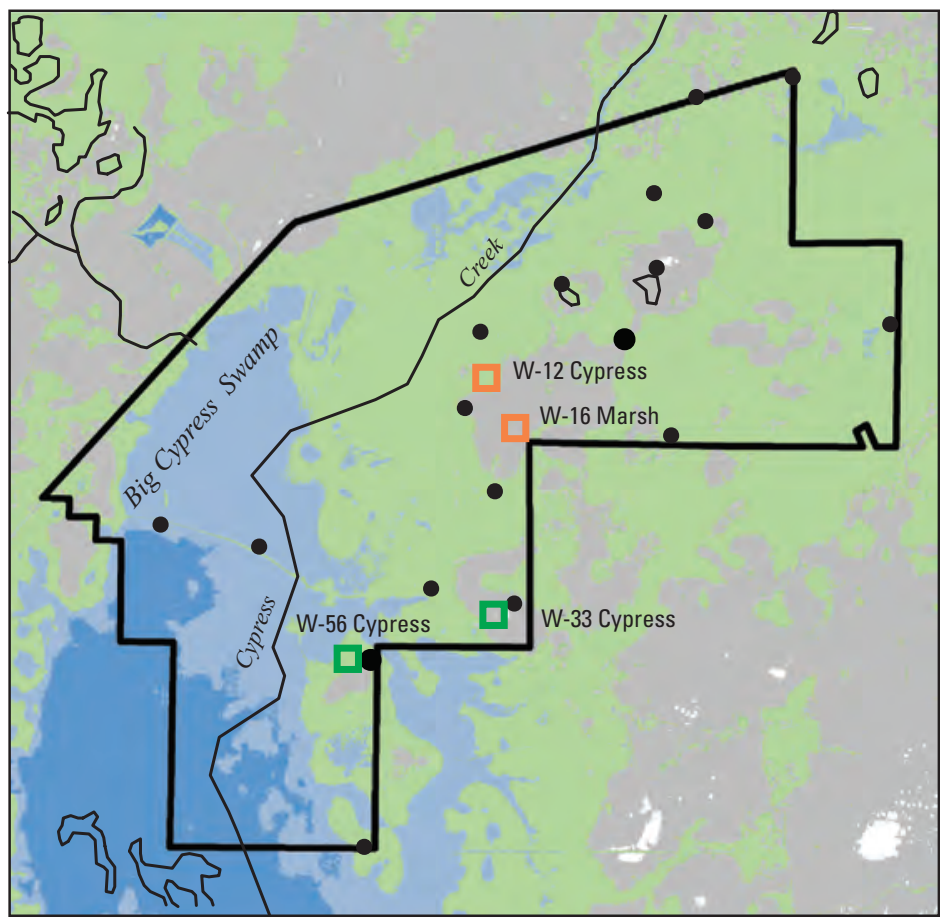

B. May 2009

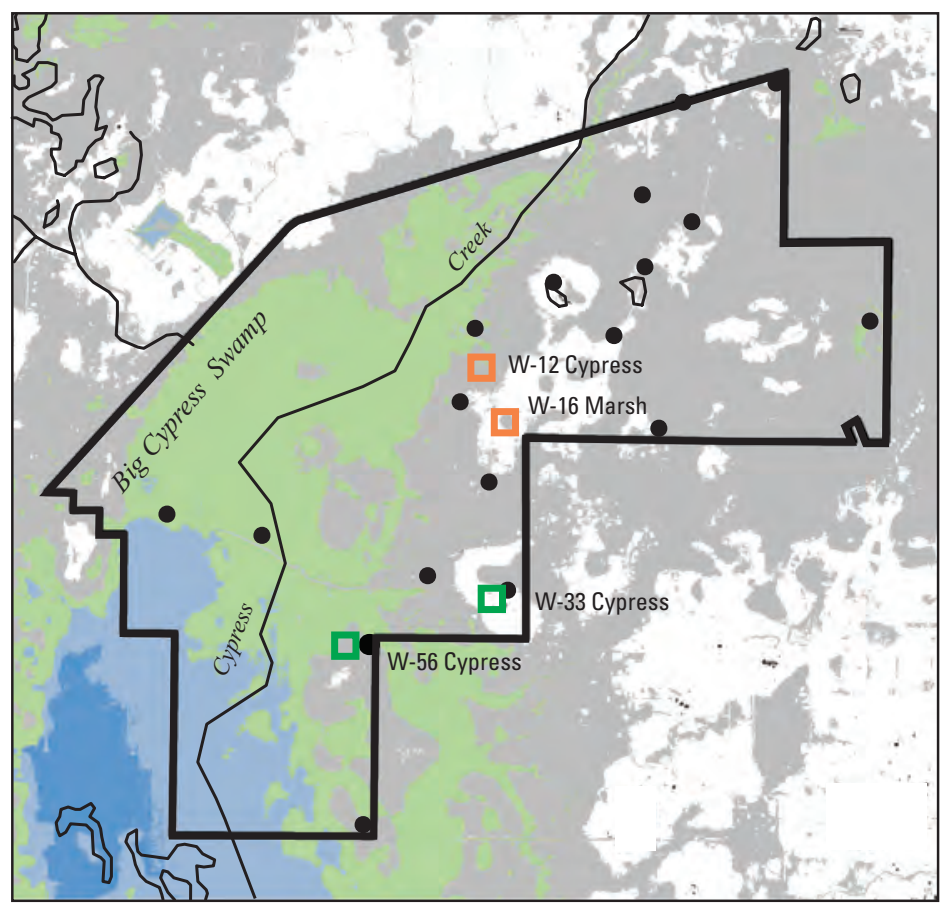

Figure 25. Elevation difference between land surface and the potentiometric surface of the Upper Floridan aquifer during $A$, September 2008, and B, May 2009 at the Cypress Creek well field. Elevation difference map, in feet, based on subtracting the potentiometric surface of the Upper Floridan aquifer during September 2008 and May 2009 from land-surface elevation data (2005 LIDAR data) provided by the Southwest Florida Water Management District. 
$1.5 \mathrm{ft}$ below the wetland perimeter (Brown and others, 1983 and 1991), whereas S-44 Cypress contained several deep depressions as much as $7 \mathrm{ft}$ below the wetland perimeter (fig. 15A). To understand the impacts of these karst features and the level of the potentiometric surface of the Upper Floridan aquifer at S-44 Cypress, two wetland-bottom elevations were used in the elevation-difference analysis. These elevations included the lowest elevation point along the wetland bottom, where the karst features are located (27.2 ft; fig. 15A), and a higher elevation ( $32.7 \mathrm{ft}$; fig. $15 \mathrm{~A}$ ) that was more representative of the "natural" wetland depth. Results for the lower elevation $(27.2 \mathrm{ft})$ indicated that the potentiometric surface of the Upper Floridan aquifer was at or near land surface, at about the same elevation as the top of the karst features. Results for the higher wetland-bottom elevation indicated that the potentiometric surface of the Upper Floridan aquifer was about $5 \mathrm{ft}$ below the wetland-bottom elevation, which was similar to the potentiometric-surface elevations measured at S-68 Cypress and Grass Prairie wetlands (fig. 26).

At Cypress Creek well field, the elevation difference between the wetland bottom and the potentiometric surface of the Upper Floridan aquifer was smallest at the minimally impacted W-56 Cypress and largest at the minimally impacted W-33 Cypress both before and after reductions (fig. 26). W-33 Cypress had the largest elevation difference among the study wetlands at Cypress Creek well field because it is higher topographically than the other wetlands on this well field (fig. 9). The land-surface elevation of W-33 Cypress is $7 \mathrm{ft}$ higher than $\mathrm{W}-56$ Cypress, and the aforementioned differences shown in figure 26 for these two sites highlight the importance of understanding the topographic setting when making comparisons between wetlands.

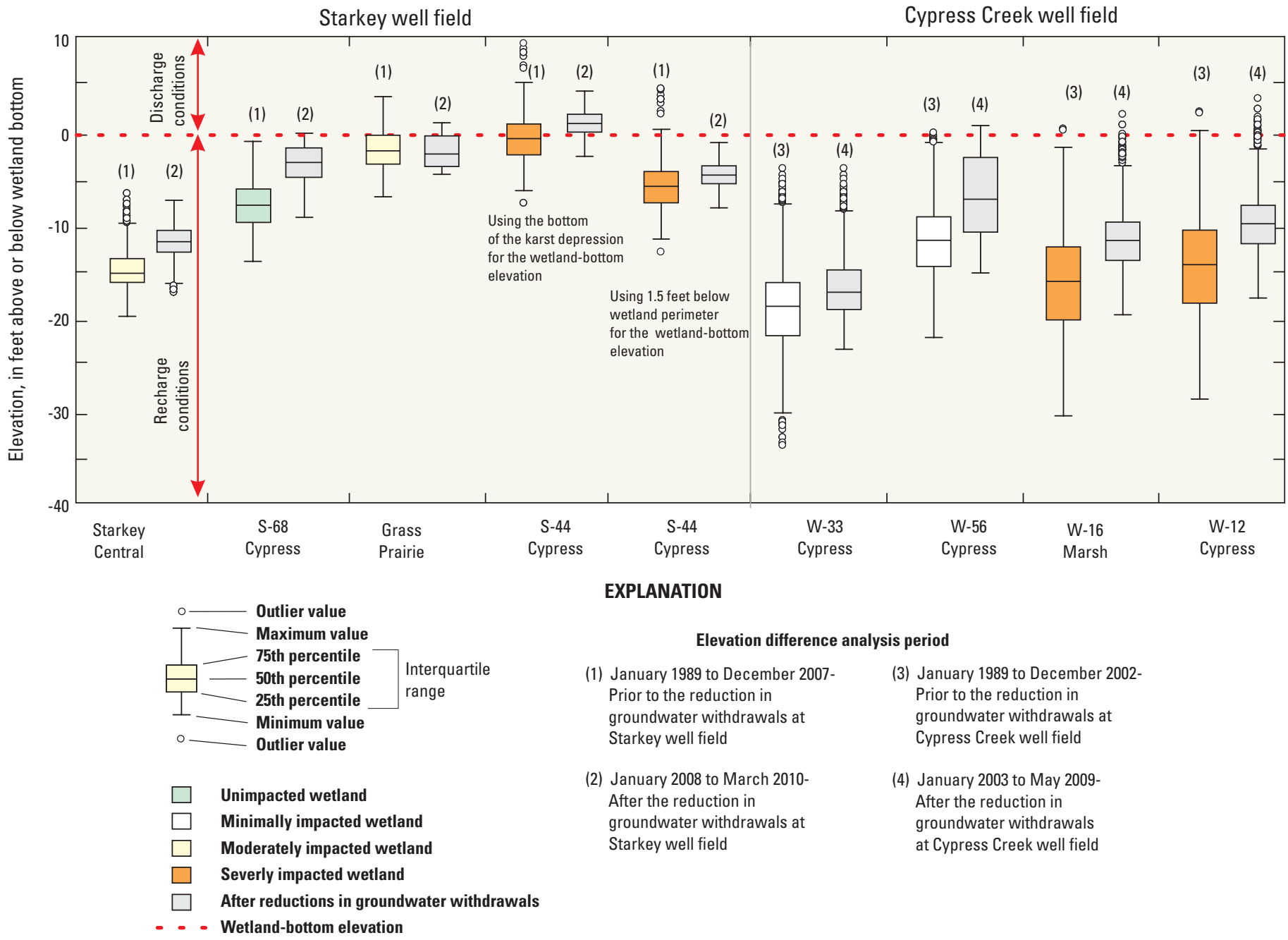

Figure 26. Elevation of the potentiometric surface of the Upper Floridan aquifer above or below the study-wetland bottom elevations prior to and after the reductions in groundwater withdrawals at the Starkey and Cypress Creek well fields. 
The severely impacted W-12 Cypress and W-16 Marsh experienced the widest range in elevation differences before reductions, due in part to the large groundwater withdrawals from this area of the well field (fig. 26). Prior to groundwater development, both of these wetlands were located in discharge areas (fig. 23) where the potentiometric surface of the Upper Floridan aquifer was either at or slightly above land surface. After groundwater development, the median level of the potentiometric surface of the Upper Floridan aquifer declined to about 14 (W-12 Cypress) and $16 \mathrm{ft}$ (W-16 Marsh) below the wetland-bottom elevation, impacting the hydrology of the wetlands (fig. 26).

The potentiometric surface of the Upper Floridan aquifer rose beneath most study wetlands at both well fields after groundwater withdrawals were reduced. At Starkey well field, the median potentiometric surface elevation increased by about 3 and $5 \mathrm{ft}$ beneath Starkey Central and S-68 Cypress wetlands, respectively (fig. 26). At Grass Prairie and S-44 Cypress wetlands, the median elevation remained about the same after groundwater withdrawals were reduced because these reductions were not concentrated in the western part of Starkey well field. At Cypress Creek well field, the median elevation increased by about $5 \mathrm{ft}$ beneath $\mathrm{W}-16$ Marsh, W-12 Cypress, and W-56 Cypress wetlands, and by about $2 \mathrm{ft}$ beneath W-33 Cypress wetland (fig. 26).

\section{Effects of Groundwater Withdrawals on Wetland Hydroperiods}

Groundwater withdrawals from wells surrounding the study wetlands were analyzed to determine the effects of these withdrawals on study wetland hydroperiods. The combined average annual withdrawal rate from wells within a 1-mi radius from the center of the study wetlands was determined prior to and after the reduction in groundwater withdrawals at the study well fields (fig. 27). Groundwater withdrawals were lowest near Grass Prairie, where four production wells were pumped at a combined average annual rate of $1 \mathrm{Mgal} / \mathrm{d}$ during 1983-2007, with no reduction in withdrawal rates during 2008-09 (fig. 27). Groundwater withdrawals were highest near W-16 Marsh, where seven production wells were pumped at a combined annual average withdrawal rate of about $16 \mathrm{Mgal} / \mathrm{d}$ during 1976-2002, after which, withdrawals were reduced to about $9 \mathrm{Mgal} / \mathrm{d}$ during 2003-08 (fig. 27).

The effects of these groundwater withdrawals are evident at the severely impacted W-16 Marsh, where the median level of the potentiometric surface of the Upper Floridan aquifer below the wetland bottom was about $16 \mathrm{ft}$ prior to groundwater withdrawal reductions (fig. 26). W-16 Marsh is located in an area of the well field that has the lowest Upper Floridan aquifer levels, as indicated by the cone of depression in appendix $3 A-B$. Two of the production wells are in close proximity to $\mathrm{W}-16$ Marsh, with distances ranging from 0.06 to $0.20 \mathrm{mi}$ (fig. $7 A$ ), locally influencing aquifer levels beneath the wetland.

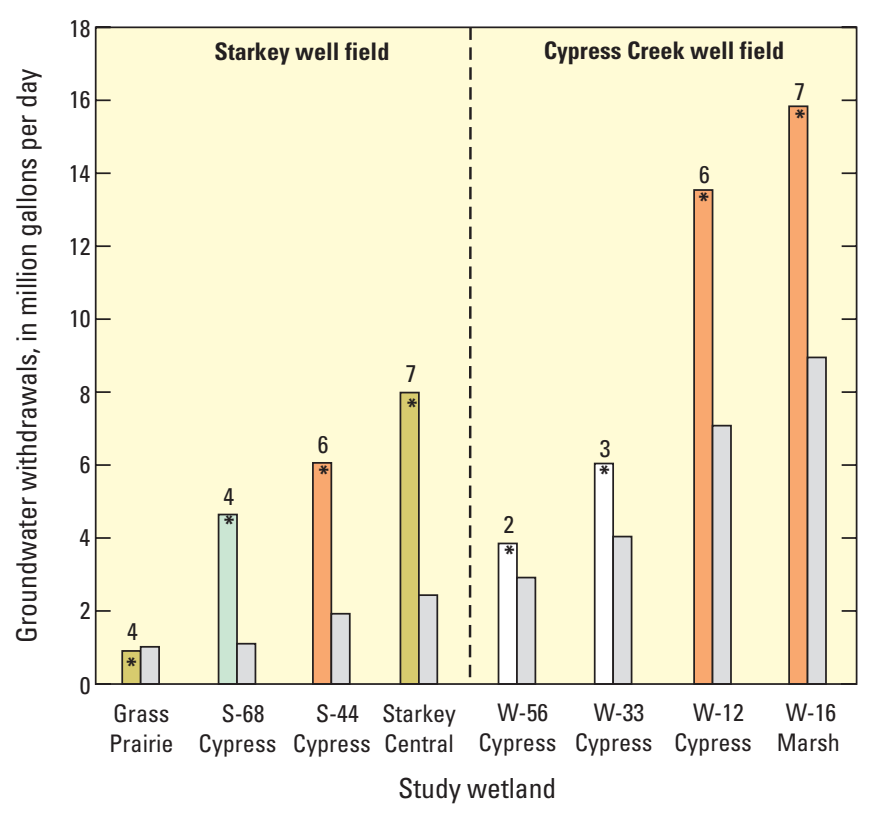

\section{EXPLANATION}

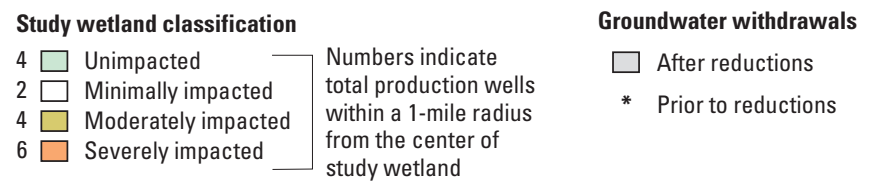

Figure 27. Groundwater withdrawals within a 1-mile radius of the center of the study wetlands prior to and after reductions in groundwater withdrawals.

Hydrographs, flooded-area maps, and flooded-area duration graphs were used to compare and contrast the hydrologic conditions of four study wetlands before and after the reductions in groundwater withdrawals at Starkey and Cypress Creek well fields (figs. 28, 29, and 30). The 1989-2009 hydrographs of the unimpacted wetland (S-68 Cypress), a minimally impacted wetland (W-33 Cypress), and two severely impacted wetlands (S-44 Cypress and W-16 Marsh) show the period of time during which the wetland water levels were above or below the wetland-bottom elevation (fig. 28). The wetland water levels for the unimpacted and minimally impacted wetlands (S-68 Cypress and W-33 Cypress, respectively) show a relatively narrow range in wetland water-level fluctuations (fig. 28A-B). In contrast, water-level fluctuations at the severely impacted S-44 Cypress are larger because the wetland has been affected by karst subsidence that has lowered the wetland-bottom elevation below the natural depth range for cypress wetlands (fig. 28C). At the severely impacted W-16 Marsh, the hydrograph shows the limited periods when the wetland contained surface water, along with the lower surficial aquifer water levels that existed below the wetland-bottom elevation (fig. 28D).

The flooded area of a wetland, when expressed as a percentage of the total wetland area, is an informative measure that can be used to characterize and compare the hydrologic 
A. S-68 Cypress, Starkey well field

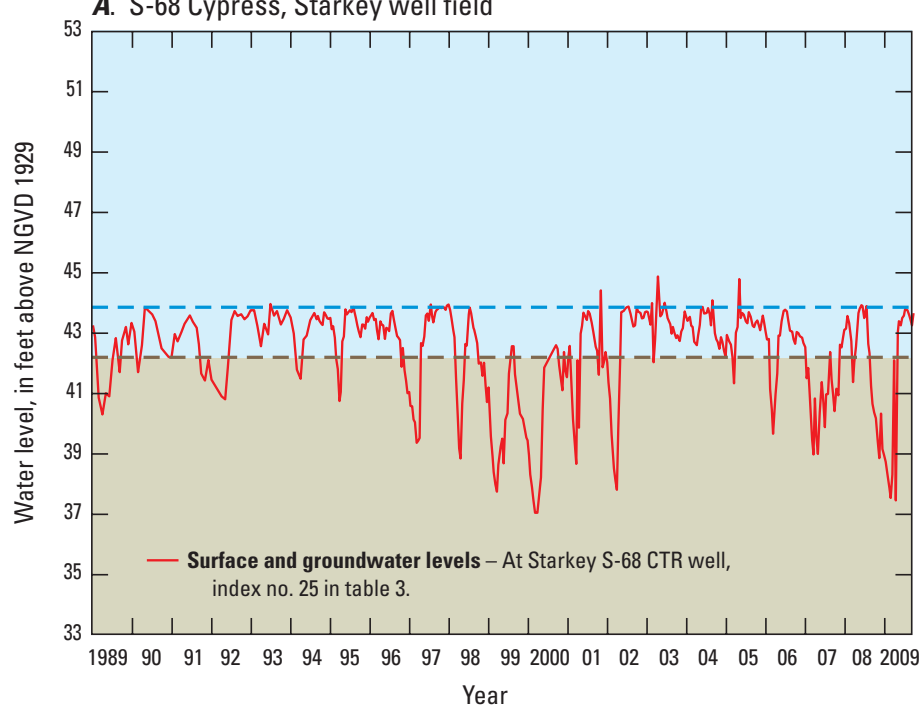

C. S-44 Cypress, Starkey well field

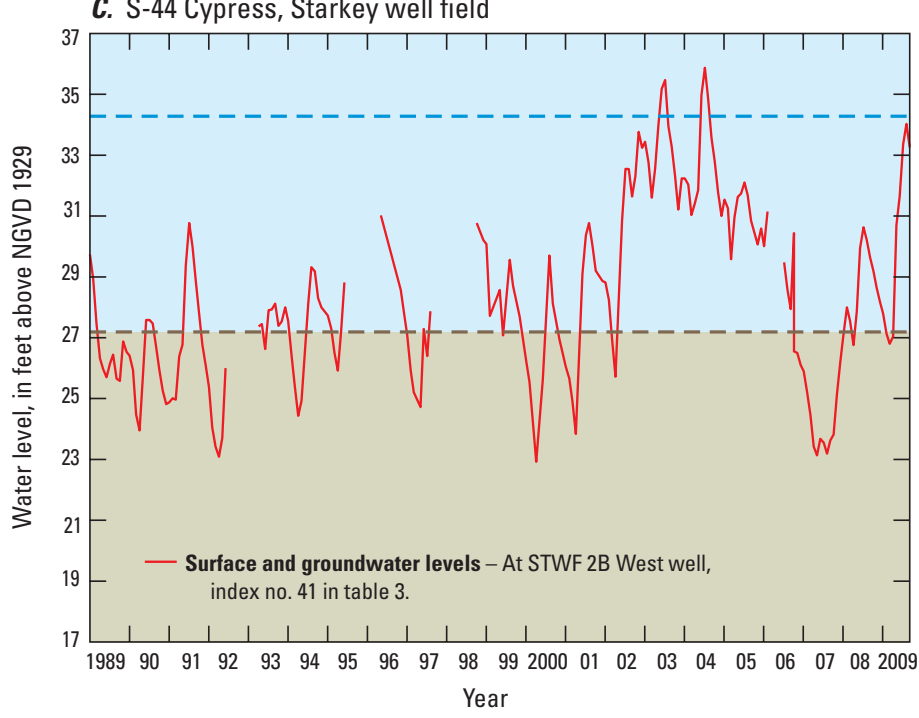

B. W-33 Cypress, Cypress Creek well field

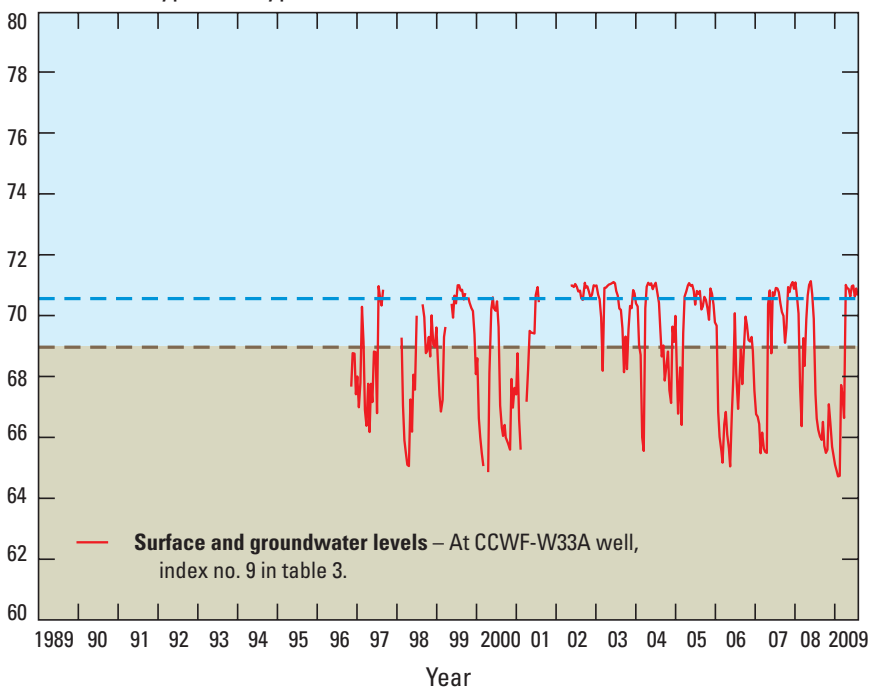

D. W-16 Marsh, Cypress Creek well field

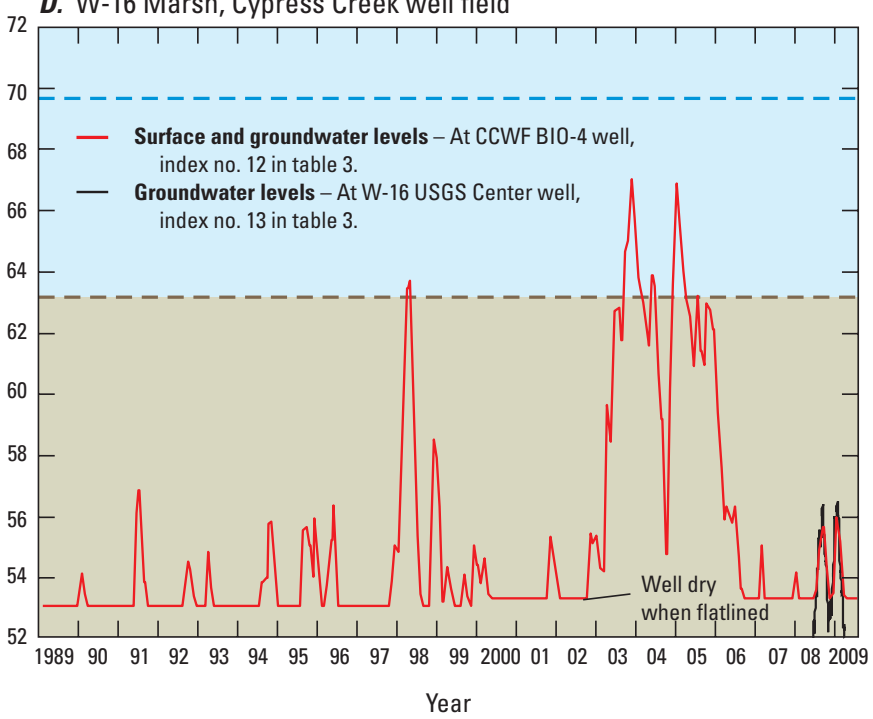

\section{EXPLANATION}

Elevation of wetland levels

Elevation of groundwater levels
- Elevation of wetland perimeter - Bathymetry data were used to determine outer edge of wetland. Water levels above wetland perimeter line indicate the wetland is flooded.

- - - Elevation when wetland is dry - Bathymetry data were used to determine lowest point of wetland.

Figure 28. Hydrographs of historical water levels at $A$, an unimpacted, $B$, a minimally impacted, and $C-D$, two severely impacted wetlands. 


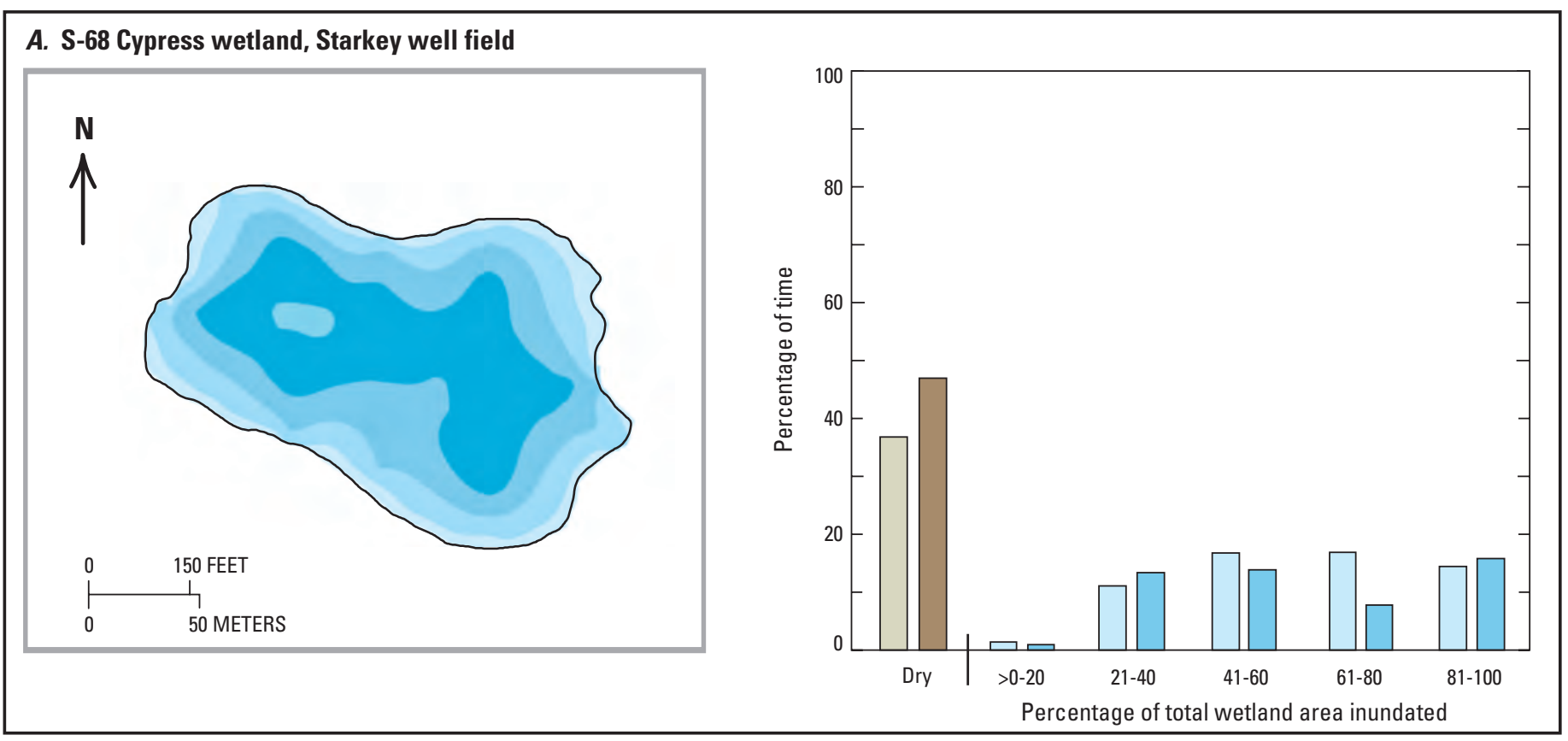

\section{B. S-44 Cypress wetland, Starkey well field}
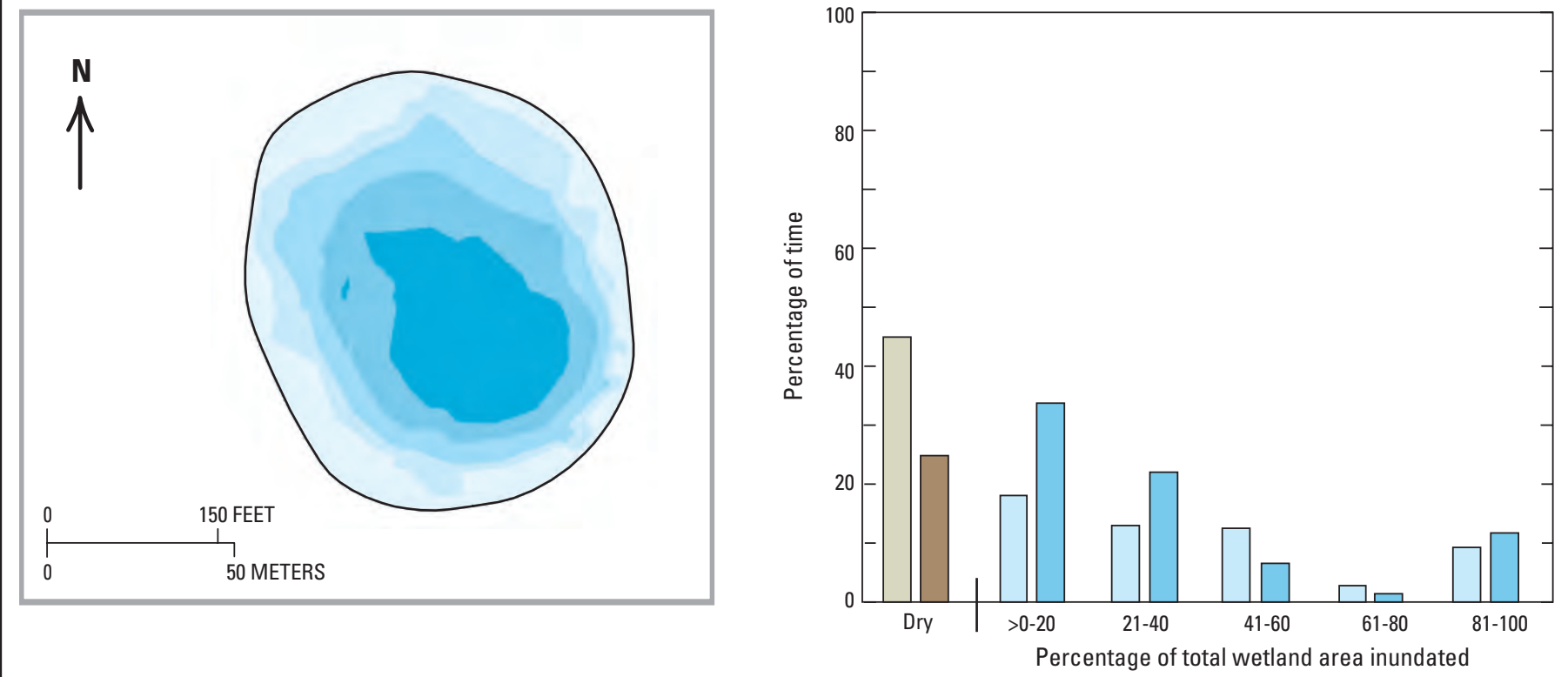

EXPLANATION

Flooded area, in percent of total wetland area

Flooded area duration

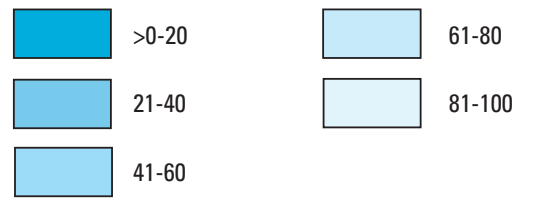

Dry during 1989-2007 (before groundwater reductions)

Dry during 2008-2009 (after groundwater reductions)

Flooded at a percent area interval during 1989-2007 (before groundwater reductions)

Flooded at a percent area interval during 2008-2009 (after groundwater reductions)

Figure 29. The shape of flooded areas at different levels of inundation, and graphs showing duration of flooding prior to and after reductions in groundwater withdrawals at A, S-68 Cypress, and B, S-44 Cypress at the Starkey well field. 


\section{A. W-33 Cypress, Cypress Creek well field}

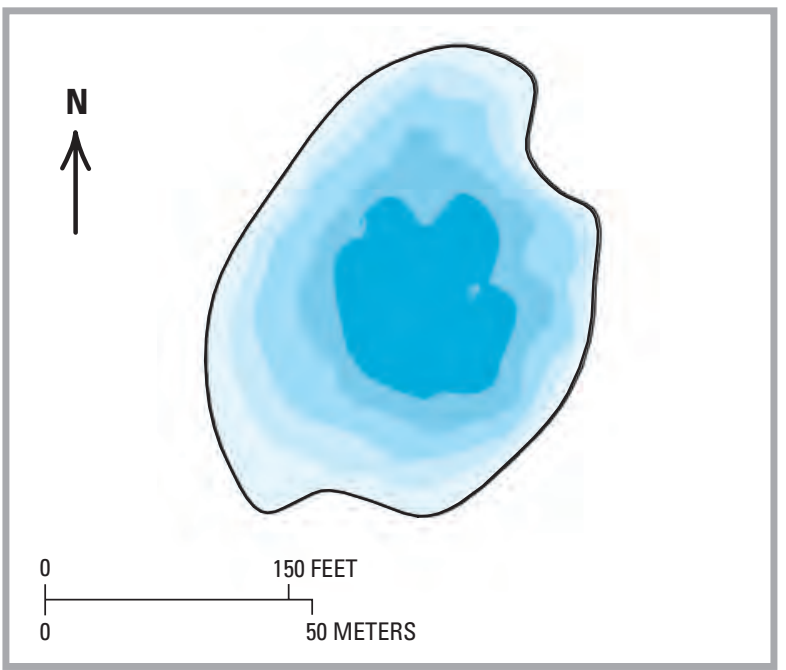

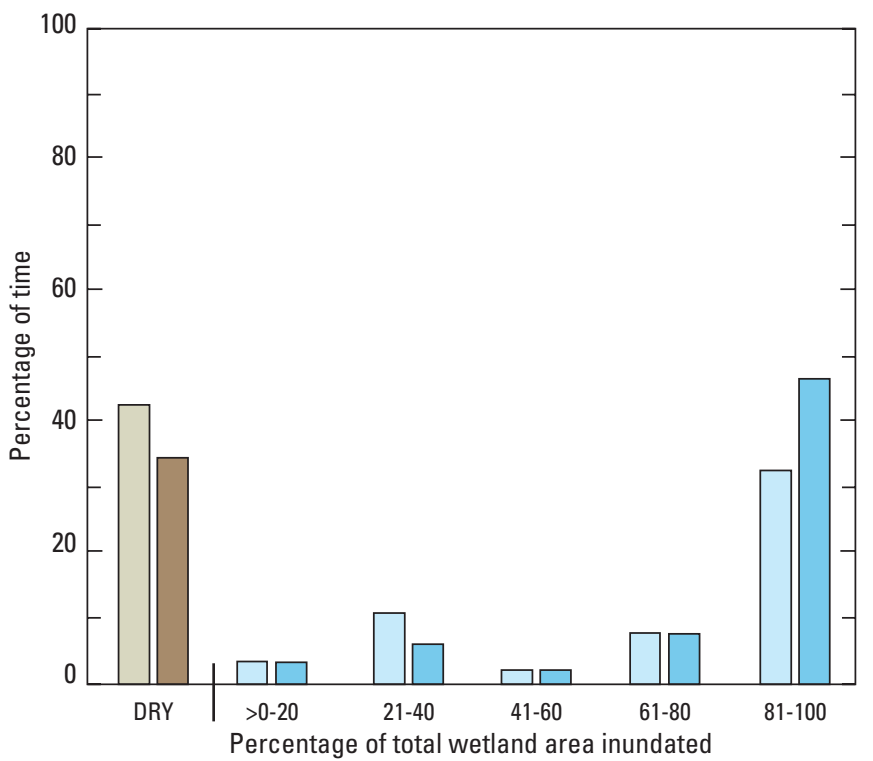

\section{B. W-16 Marsh, Cypress Creek well field}

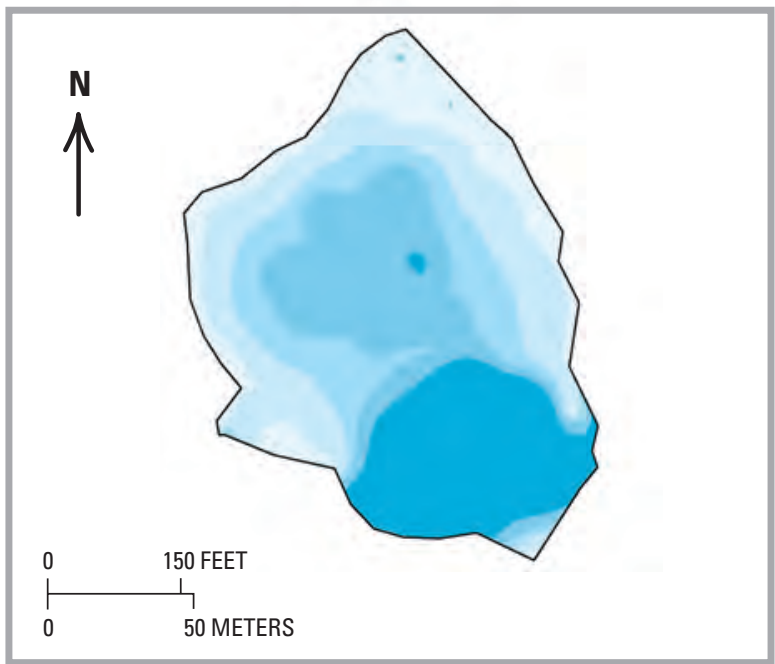

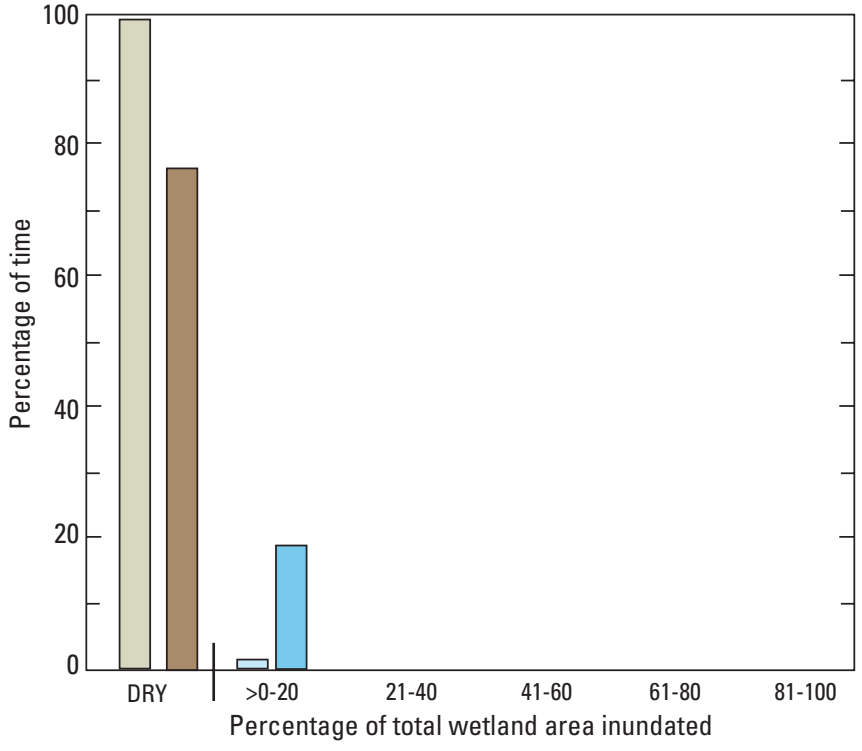

EXPLANATION

Flooded area, in percent of total wetland area

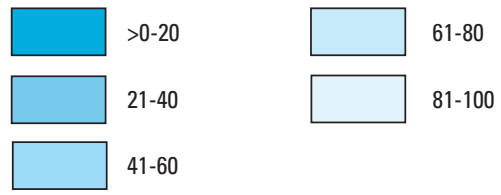

Flooded area duration

Dry during 1989-2002 (before groundwater reductions)

Dry during 2003-2009 (after groundwater reductions)

Flooded at a percent area interval during 1989-2002 (before groundwater reductions)

Flooded at a percent area interval during 2003-2009 (after groundwater reductions)

Figure 30. The shape of flooded areas at different levels of inundation, and duration graphs showing duration of flooding prior to and after reductions in groundwater withdrawals at $A, \mathrm{~W}-33$ Cypress, and $B, \mathrm{~W}-16$ Marsh at the Cypress Creek well field. 
condition of an isolated wetland in a region regardless of size (Lee and others, 2009). Maps for four of the study wetlands show the distribution of the flooded area in 20 percent intervals, and the associated flooded-area duration graphs show the percentage of time that the wetland is contained within a particular flooded-area interval (figs. 29 and 30). The floodedarea duration graphs also show the percentage of time that each wetland was dry during a particular analysis period. These contrasting hydrologic conditions reflect the wetland's response to the seasonal wet and dry periods and the influence of groundwater withdrawals.

During the 19-year period (1989-2007) at Starkey well field, S-68 Cypress and S-44 Cypress wetlands were dry 37 percent and 45 percent, respectively, and in various stages of inundation during the remaining time (fig. 29A-B). During the inundated period, S-68 Cypress was most frequently inundated in the 41-60 and 61-80 percentile ranges (fig. 29A), whereas $\mathrm{S}-44$ Cypress was most frequently inundated in the 0-20 percentile range (fig. 29B).

During a 2-year period (2008-09), the groundwater withdrawals from wells surrounding S-68 Cypress were reduced from 4.4 to about $1 \mathrm{Mgal} / \mathrm{d}$ (fig. 27) and the wetland was inundated 53 percent of the time, with almost equal intervals in the 21-40, 41-60, and the 81-100 percentile ranges (fig. 29A). Although S-68 Cypress was dry a greater percentage of time in 2008-09 than in the preceding 19 years (47 and 37 percent, respectively), the increase was probably due to the rainfall deficit during 2007-08 (fig. 2B).

The flooded area of S-44 Cypress increased during 2008-09, and the wetland was dry only 22 percent of the time. The wetland was most frequently inundated in the $>0-20$ and $21-40$ percentile ranges (fig. 29B). The increase in flooded area at S-44 Cypress was the result of the reduction in groundwater withdrawals near the wetland (from 6 to $2 \mathrm{Mgal} / \mathrm{d}$; fig. 27), and a resulting increase of about $1 \mathrm{ft}$ in the potentiometric surface for the Upper Floridan aquifer below the wetland bottom. The flooded area of S-44 Cypress during 2008-09 remained mostly within the deepest part of the wetland ( $>0-20$ percent range), where karst depressions are located, but also extended outward to the $21-40$ percent range, indicating an increase in the overall area of inundation. In addition, there was a slight increase in the $81-100$ percent range for S-44 Cypress (fig. 29B).

During a 14-year period (1989-2002) when groundwater withdrawals averaged about $26 \mathrm{Mgal} / \mathrm{d}$ at the Cypress Creek well field (fig. 5C), the minimally impacted W-33 Cypress was dry 43 percent of the time and was most frequently inundated in the 81-100 percent range (fig. 30A). In contrast, the severely impacted W-16 Marsh was dry 99 percent of the time and was only inundated in the $>0-20$ percentile range (fig. 30B). W-16 Marsh was inundated only in February and March 1998 (fig. 28D) during the 1997-98 El Niño event (National Oceanic and Atmospheric Administration, 2010). The groundwater withdrawals surrounding W-16 Marsh were much greater than at W-33 Cypress, averaging about 16 and $6 \mathrm{Mgal} / \mathrm{d}$, respectively (fig. 27). In addition to the large withdrawals that occur near W16 Marsh, four sinkholes located along the wetland bottom in 1982 likely influenced the downward leakage potential for this wetland (Rochow, 1983c).

During a 7-year period (2003-09) when groundwater withdrawals were reduced from an annual rate of 26 (1998-2002) to about $15 \mathrm{Mgal} / \mathrm{d}$ (2003-09) at Cypress Creek well field (fig. 5C), the inundation period for W-33 Cypress increased from 57 to 66 percent, and the wetland was again most frequently inundated in the 81-100 percent range (fig. 30A). Withdrawal rates from wells near W-33 Cypress were reduced by about $2 \mathrm{Mgal} / \mathrm{d}$ during this period (fig. 27). Due to this reduction, the potentiometric surface of the Upper Floridan aquifer rose by about $2 \mathrm{ft}$ beneath the wetland bottom (fig. 26). The increase in the potentiometric surface of the Upper Floridan aquifer beneath the wetland bottom (fig. 26) helped reduce the potential for downward leakage from this wetland.

Even though the groundwater withdrawals from individual wells surrounding W-16 Marsh were reduced by almost half (from 16 to $9 \mathrm{Mgal} / \mathrm{d}$ ) during 2003-09 (fig. 27), the wetland remained dry 77 percent of the time and was inundated only 23 percent of the time (fig. 30B). The wetland was inundated only twice during the post groundwater-reduction period (2003-09), and only during extreme rainfall events (fig. 28D). The first flooding event occurred during August 2003, following a year when rainfall was over 20 in. above average. Because of the cumulative rainfall, the wetland remained about 64 percent inundated for several weeks. The second flooding event occurred during September 2004 after several tropical storms and hurricanes passed through the area, and following a year when rainfall was over 23 in. above average (fig. 28D). Consequently, over 63 percent of $\mathrm{W}-16$ Marsh was inundated for several months in late 2004. After both of these flooding events, the water level in the wetland quickly receded, indicating the interconnection between the wetland and underlying aquifer. Following the reductions in groundwater withdrawals, the median 5-ft increase in the potentiometric surface of the Upper Floridan aquifer below the wetland bottom (fig. 26) has not reduced the downward leakage potential at this wetland, indicating the influence of karst subsidence.

\section{Ranking of Factors Influencing the Hydrologic Recovery of Wetlands}

Ranking of factors that influence the hydrologic recovery of wetlands was used to determine the relative recovery potential of water levels in study wetlands following reductions in groundwater withdrawals. The total ranking was determined by summing the rank assigned to each factor. Ranking for three of the four factors (topographic setting, permeability of sediments underlying wetlands, and depth to the potentiometric surface of the Upper Floridan aquifer below the wetlands) was based on whether each factor had a positive influence, a neutral influence, or a negative influence (ranking 
numbers 1, 2, and 3, respectively). Ranking for the remaining factor (karst feature near or underlying wetland) was based on whether karst features were absent, near, or underlying the study wetland (ranking numbers as 1, 2, and 3, respectively). A wetland with a minimum total rank of 4 indicated that the wetland is positively influenced by all the factors and is in good hydrologic condition. In contrast, a maximum total rank of 12 indicated that water levels in the wetland were not likely to recover under current conditions. This ranking system can be used as a preliminary tool to help make more informed decisions about wetland water-level recovery at other wetlands in the study area using available information. Although qualitative, rankings are an informative and practical tool for comparing the influence of multiple factors on wetland hydrology.

Based on this ranking system, S-68 Cypress at Starkey well field has the lowest possible total rank of 4, indicating the good hydrologic condition of this wetland. The wetland is positively influenced by its low-lying topographic setting where surface-water connections can be made easily to nearby Cross Creek Branch, intact low-permeability layers below the wetland, a lack of karst features, and a relatively shallow depth of the potentiometric surface of the Upper Floridan aquifer below the wetland bottom (about $7 \mathrm{ft}$ ) (table 5 and fig. 31).

W-33 Cypress at Cypress Creek well field, with a total rank of 6, has good potential for hydrologic recovery because of the thick, low-permeability sediment layers underlying the wetland that are not influenced by karst subsidence. This wetland is neutrally influenced by other factors; the relatively high topographic setting compared to surrounding wetlands (fig. 9), and a large median depth (about $16 \mathrm{ft}$ after the reduction in groundwater withdrawals) to the potentiometric surface of Upper Floridan aquifer - the greatest depth below any of the study wetlands (fig. 26). During the groundwater withdrawal reductions of 2003-09, there was a median 2-ft increase in the potentiometric surface of the Upper Floridan aquifer below W-33 Cypress, resulting in an increase in duration of the hydroperiod and flooded area of the wetland (fig. 30A). Even with the relatively large depth to the potentiometric surface of the Upper Floridan aquifer below this wetland after the reductions in groundwater withdrawals (fig. 26), this analysis indicates that the downward leakage potential is substantially reduced for wetlands in areas where the underlying sediments are thick, impermeable, and are not influenced by karst subsidence.

W-56 Cypress, located in the Cypress Creek well field, was assigned a total rank of 7 (table 5). Sediments at this wetland are more permeable than those at W-33 Cypress, and there are no apparent karst features underlying or near this wetland. Neutral factors were the topographic setting (fig. 9) and median depth (about $11 \mathrm{ft}$ ) to the potentiometric surface of Upper Floridan aquifer below the wetland (fig. 26). During the groundwater withdrawal reductions of 2003-09, there was a median 5-ft increase in the potentiometric surface of the Upper Floridan aquifer below this wetland. As a result, the flooded duration at W-56 Cypress increased from 28 to 34 percent, and the flooded area of the wetland increased mostly in the 81-100 percent inundation range.

The six remaining study wetlands (Grass Prairie, Starkey Central, S-44 Cypress, Cypress Bridge 01, W-12 Cypress, and $\mathrm{W}-16 \mathrm{Marsh}$ ) are affected by adjacent or underlying karst features, and were assigned total ranks ranging from 7 to 12 (table 5). The karst features provide pathways for downward leakage, and the extent of wetland recovery when withdrawals were reduced was dependent on how deep the potentiometric surface of the Upper Floridan aquifer was below the study wetland.

For example, because of karst subsidence at S-44 Cypress, the wetland bottom is about $5 \mathrm{ft}$ deeper than a typical cypress wetland in several areas. The controlling factor in the recovery of this wetland is the shallow depth to the potentiometric surface of the Upper Floridan aquifer below the wetland (fig. 26). As the potentiometric surface approached land surface below this wetland, as a result of reductions in groundwater withdrawals during 2008-09, the duration of flooding increased, and the flooded area expanded from mostly in the $>0-20$ percent area (where karst features are located) into the 21-40 percent inundated area. For S-44 Cypress, the presence of the karst features did not affect the hydrologic recovery of the wetland because the elevation of the potentiometric surface of the Upper Floridan aquifer was about equal to the wetlandbottom elevation, limiting the downward leakage potential.

W-12 Cypress and W-16 Marsh, assigned total ranks of 10 and 12, respectively, are both located in the region of Cypress Creek well field where large groundwater withdrawals are concentrated, and both have reported sinkholes or subsidence beneath or near the wetlands. Prior to groundwater development, both wetlands were located in groundwater discharge areas where the potentiometric surface of the Upper Floridan aquifer was either at or slightly above land surface (fig. 23). Prior to reductions in groundwater withdrawals, the median depth of the potentiometric surface of the Upper Floridan aquifer was about 14 to $16 \mathrm{ft}$ below the wetland bottoms (fig. 26). Despite a median 5-ft increase in the potentiometric surface of the Upper Floridan aquifer after groundwater reductions (2003-09), these two wetlands have remained mostly dry, except during the high-rainfall events in 2003-05.

During these inundation periods at W-16 Marsh during 2003-05, the wetland water levels receded after 1 to 2 months, indicating a good interconnection with the underlying aquifers (fig. 28D). W-12 Cypress retained surface water for longer periods during 2003-05 compared to W-16 Marsh. W-12 Cypress may benefit from its relatively low topographic setting, which facilitates inflow from other surface-water features during high-water periods (fig. 9). In addition, karst subsidence is not as severe at $\mathrm{W}-12$ Cypress wetland compared to $\mathrm{W}-16$ Marsh, where several karst features are present in the wetland bottom. W-16 Marsh also is about $0.06 \mathrm{mi}$ from a production well that affects water levels beneath this wetland. 
Table 5. Ranking of the study wetlands based on the factors that influence the hydrologic recovery of wetlands in the Northern Tampa Bay area.

\begin{tabular}{|c|c|c|c|c|c|}
\hline \multirow[b]{2}{*}{ Study wetland } & \multicolumn{5}{|c|}{ Factors that influence the hydrologic recovery of wetlands } \\
\hline & $\begin{array}{l}\text { Topographical } \\
\text { setting of } \\
\text { wetland }^{1}\end{array}$ & $\begin{array}{l}\text { Permeability of } \\
\text { sediments } \\
\text { underlying } \\
\text { wetland' }^{1}\end{array}$ & $\begin{array}{l}\text { Karst feature } \\
\text { near or underlying } \\
\text { wetland }^{2}\end{array}$ & $\begin{array}{l}\text { Depth to the } \\
\text { potentiometric surface } \\
\text { of the Upper Floridan } \\
\text { aquifer below } \\
\text { wetland }\end{array}$ & Total \\
\hline \multicolumn{6}{|c|}{ Starkey well field } \\
\hline S-68 Cypress & 1 & 1 & 1 & 1 & 4 \\
\hline Grass Prairie & 1 & 2 & 3 & 1 & 7 \\
\hline Starkey Central & 2 & 2 & 2 & 1 & 7 \\
\hline S-44 Cypress & 2 & 2 & 3 & 1 & 8 \\
\hline \multicolumn{6}{|c|}{ Cypress Creek well field } \\
\hline W-33 Cypress & 2 & 1 & 1 & 2 & 6 \\
\hline W-56 Cypress & 2 & 2 & 1 & 2 & 7 \\
\hline W-12 Cypress & 1 & 3 & 3 & 3 & 10 \\
\hline W-16 Marsh & 3 & 3 & 3 & 3 & 12 \\
\hline \multicolumn{6}{|c|}{ Cypress Bridge well field } \\
\hline Cypress Bridge 01 & 3 & 2 & 3 & 1 & 9 \\
\hline
\end{tabular}

'Ranking of hydrologic factor: 1, positive influence; 2, neutral influence; 3, negative influence.

${ }^{2}$ Ranking for karst features: 1 , no evidence of karst features; 2 , karst features near wetland; 3 , karst features underlying wetland.

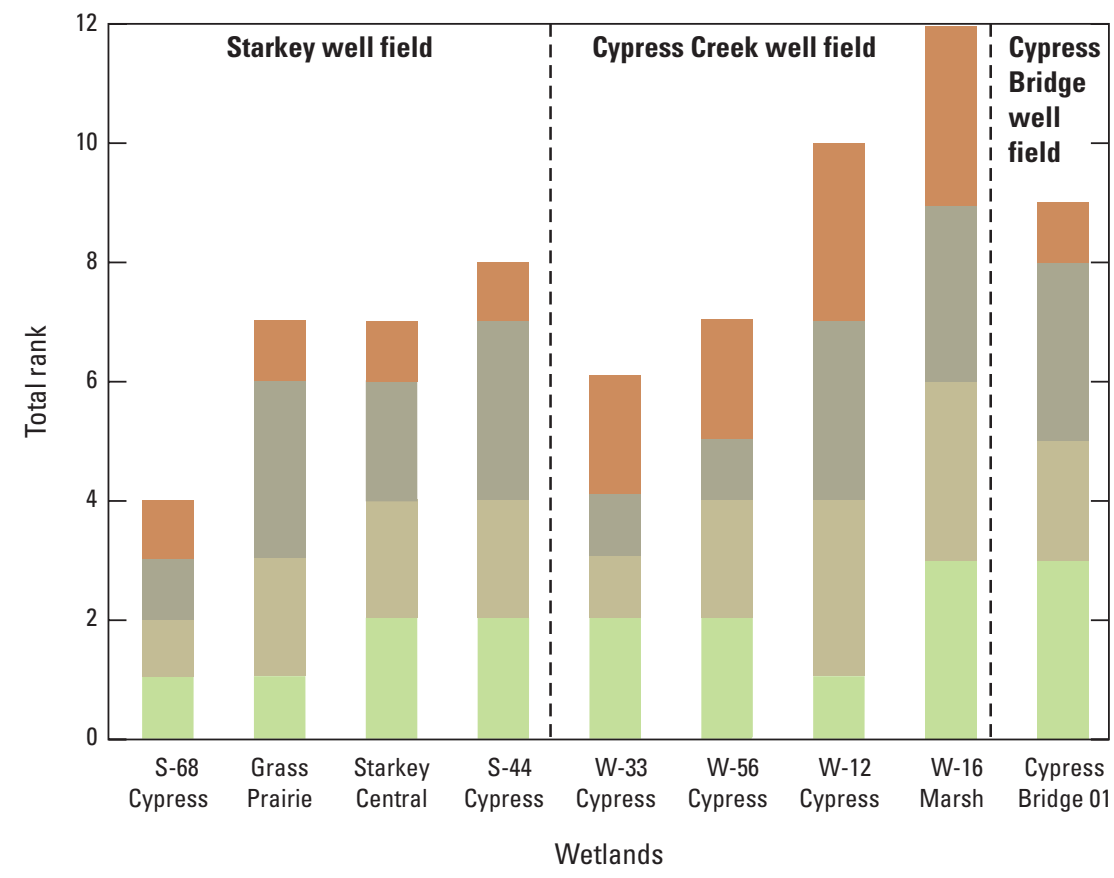

EXPLANATION

Depth to the potentiometric surface - Of the

Upper Floridan aquifer underlying wetland.

Karst features - Located near or underlying wetland.

Permeability of sediments - Underlying wetland.

Physical setting of wetland

Figure 31. Total ranking of factors that influence the hydrologic recovery of wetlands in the Northern Tampa Bay area. 
Because of karst subsidence at both $\mathrm{W}-12$ Cypress and W-16 Marsh, wetland water levels will not recover if the potentiometric surface of the Upper Floridan aquifer remains at its current depth of about 9 and $11 \mathrm{ft}$ below the wetland bottom, respectively. Both wetlands retain water for only several months during high rainfall periods when groundwater withdrawals are reduced and the potentiometric surface of the Upper Floridan aquifer increases.

Based on these rankings and the response of study wetlands to reductions in groundwater withdrawals, two factors primarily limited the hydrologic recovery of wetlands: the presence of recent karst activity below or near the wetlands, and the depth to the potentiometric surface of the Upper Floridan aquifer below the wetlands. Breaches and breaks in the near-surface sediment layers or the intermediate confining unit due to sinkhole activity beneath the wetlands provide pathways for downward leakage, and the leakage potential increases when the depth to the potentiometric surface of the Upper Floridan aquifer is substantially below the wetland most of the time.

Low-permeability layers and the absence of adjacent or underlying karst features improve a wetland's ability to recover if groundwater withdrawals are reduced. In this setting, intact subsurface layers help retain water within and beneath the wetland and limit the downward leakage potential, even when water levels in the Upper Floridan aquifer are lower.

A relatively low topographic setting was found to influence wetlands during high-water periods because it facilitates surface-water connections to other wetlands and other surface-water bodies through low-lying surface-water channels. Wetland hydroperiods were longer during wet conditions for wetlands in low topographic settings compared to wetlands in higher topographic settings.

\section{Summary}

More than 33,000 wetlands are located throughout the Northern Tampa Bay area in Florida, with the majority (81 percent) consisting of freshwater wetlands. The numerous wetlands in the study area are widely distributed, relatively small, and are typically isolated. In the rapidly developing area of Northern Tampa Bay, anthropogenic impacts such as wetland losses, agricultural and urban development, construction of roadways and ditches, and the influence of groundwater withdrawals have provided challenges to maintaining the hydrologic and ecologic functions of this resource. Long-term groundwater withdrawals from well fields, along with a series of extended droughts in the Northern Tampa Bay area, have lowered the potentiometric surface of the Upper Floridan aquifer, which has induced downward leakage from the surficial aquifer and wetlands in areas within and around the well-field boundaries. Water-level declines in these wetlands have reduced the wetland hydroperiod, and in some cases, caused a series of side effects including replacement of wetland-dependent plant species with upland species, introduction of invasive plant species, drying and compaction of wetland-bottom sediments, tree fall, intense fires, and loss of habitat for aquatic or water-dependent wildlife.

A reduction in groundwater withdrawals from the Northern Tampa Bay well fields was initiated in mid-2002 to improve the hydrologic condition of local wetlands by allowing groundwater and wetland water levels to recover to previously higher levels. The groundwater reductions began in late 2002 and 2007 for Cypress Creek and Starkey well fields, respectively. As a result of this reduction, the potentiometric surface of the Upper Floridan aquifer in 2009 has risen at two study well fields, with the median rise ranging from about 2 to $5 \mathrm{ft}$ at Cypress Creek well field and 0 to $5 \mathrm{ft}$ at Starkey well field. In response to the reduction in groundwater withdrawals, water levels in some long-term monitored wetlands have recovered, while others have not recovered as expected.

To understand why some wetland water levels have not recovered, an unimpacted wetland and eight wetlands affected to varying degrees by well field pumping were examined at Starkey, Cypress Creek, and Cypress Bridge well fields. The study wetlands were examined based on four factors known to influence the hydrologic condition of the wetlands in west-central Florida, including the topographic setting, the permeability of underlying sediments, recent karst activity, and the depth to the potentiometric surface of the Upper Floridan aquifer beneath the wetland bottom. This analysis provided an indication of the hydrologic condition of each wetland, and which of the four factors could be limiting the recovery of wetland water levels.

When all other factors that influence the hydrologic condition of wetlands are the same, wetlands in a low-lying topographic setting have a greater potential to recover when groundwater withdrawals are reduced. Comparison of the physical setting of wetlands in the study area indicated that a low-lying topographic setting relative to the surrounding area benefited the hydrologic condition of isolated wetlands. Compared to wetlands in higher areas, those in lower areas had longer hydroperiods partly because of their greater ability, during wet conditions, to establish surface-water connections to other isolated wetlands and surface-water bodies through low-lying surface-water channels. Relatively low-lying wetlands surrounded by uplands have a greater potential to be in either a groundwater discharge or flow-through setting and benefit from greater groundwater inflow or reduced leakage than wetlands in higher topographic settings.

The continuity and the permeability of the sediments underlying the study wetlands substantially affected the hydrologic condition of the wetlands. The absence of karst features below or near the wetland and low permeability sediments underlying the wetland both improved the ability of wetlands to recover when groundwater withdrawals were reduced. Several aspects of the geologic framework helped maintain the hydrology of shallow depressional wetlands in the study area, including: (1) a thin clay layer in the nearsurface wetland-bottom sediments that slows the downward 
movement of water from the wetland; (2) a clay or hard-pan layer that lies about 5 to $10 \mathrm{ft}$ below the wetland bottom that retards the downward movement of groundwater underlying the wetland; and (3) an intact or thick clay layer of low permeability, referred to as the intermediate confining unit, that slows the movement of water between the wetland/surficial aquifer and the Upper Floridan aquifer.

Recent karst subsidence activity underlying or near the wetlands facilitated the hydrologic decline of several of the study wetlands. Several aspects of the karst geologic framework enhance the connection between the wetland/surficial aquifer and the underlying Upper Floridan aquifer, including (1) sinkholes or depressional piping features that have formed in the wetland bottom and extend through the clay or hardpan layer underlying the wetlands; (2) sinkholes or depressional piping features that have formed near the perimeter of the wetland; and (3) an intermediate confining unit that contains breaches or is thin, absent, or is highly permeable. Breaches or breaks in the underlying surficial layers or in the intermediate confining unit due to karst subsidence activity provide pathways for downward leakage to the underlying Upper Floridan aquifer, especially when wetlands are located in recharge areas.

Six of the nine wetlands examined in this study had varying degrees of localized karst subsidence underlying or near them based on bathymetric and ground-penetrating radar surveys, water-level data, and topographic analysis. The most severely impacted wetland (W-16 Marsh) was found to have karst subsidence features along the wetland bottom, in addition to a large vertical separation (median $15 \mathrm{ft}$ ) between the potentiometric surface of the Upper Floridan aquifer and the wetland-bottom elevation. However, wetlands that had both karst subsidence in the wetland bottom and a shallow depth to the potentiometric surface, such as S-44 Cypress, had longer periods of inundation during the groundwater reduction period. At this wetland, the presence of karst features did not affect the hydrologic recovery of the wetland because the elevation of the potentiometric surface of the Upper Floridan aquifer was about the same as the wetland-bottom elevation, limiting the downward leakage potential.

The increase in the potentiometric surface of the Upper Floridan aquifer below the wetland-bottom elevation was the primary factor affecting the hydrologic recovery of the study wetlands, especially those affected by karst subsidence. Two study wetlands affected by karst subsidence (W-12 Cypress and $\mathrm{W}-16 \mathrm{Marsh}$ ), remained mostly dry during the period of groundwater withdrawal reductions (2003-09), despite a median 5 - $\mathrm{ft}$ increase in the potentiometric surface of the Upper Floridan aquifer below the wetlands. Both wetlands are located in an area of the well field where large groundwater withdrawals are concentrated, and during the last 20 years of water-level data collection (1989-2009), both were inundated only during periods of extreme rainfall. During these inundation periods, the wetland water levels receded after 1 to 2 months, indicating good interconnection with the underlying aquifers. Because of this interconnection, water levels for these wetlands and other wetlands impacted by karst subsidence in this region will not recover if the potentiometric surface of the Upper Floridan aquifer remains at the current (2009) median depth of about $10 \mathrm{ft}$ below the wetland-bottom elevation. 


\section{References Cited}

Aucott, W.R., 1988, Areal variation in recharge to and discharge from the Floridan aquifer system in Florida: U.S. Geological Survey Water-Resources Investigations Report 88-4057, 1 sheet.

Bailey, J.J., 1994, Assessing long-term impacts of ditching and grazing using GIS and undisturbed reference wetlands: Master's thesis presented to the University of Florida, Center for Wetlands, Gainesville, 94 p.

Barr, G.L., 1993, Applications of ground penetrating radar methods in determining hydrogeologic conditions in a karst area, west-central Florida: U.S. Geological Survey WaterResources Investigation Report 92-4141, 26 p.

Berryman and Hennigar, Inc., 2000, Soil subsidence annual report (water year 1998): Clearwater, Fla., Report prepared for Tampa Bay Water, $77 \mathrm{p}$.

Bidlake, W.R., Woodham, W.M., and Lopez, M.A., 1996, Evapotranspiration from areas of native vegetation in westcentral Florida: U.S. Geological Survey Water-Supply Paper $2430,35 \mathrm{p}$.

Biebighauser, T.R., 2007, Wetland drainage, restoration, and repair: Lexington, Ky., The University Press of Kentucky, $241 \mathrm{p}$

Brown, M.T., Gettleson, C., Habercorn, J., and Roguski, S., 1991, The role and importance of depth and duration of flooding in the maintenance and conservation of wetland functions and values: Management implications and strategies: Prepared for the Southwest Florida Water Management District; Final Report, University of Florida, Center for Wetlands, Gainesville, 199 p.

Brown, M. T., Starnes, E.M., Diamond, C., Dunn, B., McKay, P., Noonan, M., Schreiber, S., Sendzimir, J., Thompson, S., and Tighe, B., 1983, A wetlands study of Seminole County: Identification, evaluation, and preparation of development standards and guidelines: Final Report to Seminole County; Technical Report 41, University of Florida, Center for Wetlands, Gainesville, 284 p.

Buono, Anthony, Spechler, R.M., Barr, G. L., and Wolansky, R. M., 1979, Generalized thickness of the confining bed overlying the Floridan aquifer, Southwest Florida Water Management District: U.S. Geological Survey WaterResources Investigations Open-File Report 79-1171, 1 sheet.

Carr, D.W., Leeper, D.A., and Rochow, T.F., 2006, Comparison of six biologic indicators of hydrology and the landward extent of hydric soils in west-central Florida, USA cypress domes: Wetlands, No. 26, p. 1,012-1,019.
Carter, V. 1986, An overview of the hydrologic concerns related to wetlands in the United States: Canadian Journal of Botany, v. 64, no. 2, p. 364-374.

Dahl, T.E., 1990, Wetland losses in the United States 1780s to 1980s: Washington, D.C., U.S. Fish and Wildlife Service report, $21 \mathrm{p}$.

Dahl, T.E., 2000, Status and trends of wetlands in the conterminous United States 1986 to 1997: Washington D.C., U.S. Fish and Wildlife Service report, $82 \mathrm{p}$.

Dahl, T.E., 2005, Florida's wetlands: An update on status and trends 1985 to 1996: Washington D.C., U.S. Fish and Wildlife Service report, $80 \mathrm{p}$.

Dahl, T.E., 2006, Status and trends of wetlands in the conterminous United States 1998 to 2004: Washington D.C., U.S. Fish and Wildlife Service report, 112 p.

Dooris, P.M., Dooris, G.M., Rochow, T.F., and Lopez, M., 1990, The effects on wetland vegetation and habitat value caused by altered hydroperiods resulting from groundwater withdrawals in central Florida: Brooksville, Southwest Florida Water Management District Environmental Section Technical Report 1990-1, 18 p.

Ewel, K.C., and Odum, H.T., eds., 1984, Cypress swamps: Gainesville, University Presses of Florida.

Ewel, K.C., and Wickenheiser, L.P.,1988, Effect of swamp size on growth rates of cypress (Taxodium distichum) trees: American Midland Naturalist, v. 120, p. 362-370.

Farnsworth, R.K., Thompson, E.S., and Peck, E.L., 1982, Free water surface exchange, 1956-70, map 3 of evaporation atlas for the contiguous 48 United States: National Oceanic and Atmospheric Administration Technical Report NWS 33, scale 1:5,000,000.

Frayer, W.E., and Hefner, J.M., 1991, Florida wetlands: Status and trends, 1970's to 1980's: Atlanta, Georgia, U.S. Fish and Wildlife Service report, $33 \mathrm{p}$.

Freeman, L.A., Carpenter, M.C., Rosenberry, D.O., Rousseau, J.P., and others, 2004, Use of submersible pressure transducers in water-resources investigations: U.S. Geological Survey Techniques of Water Resources Investigations, book 8, chap. A3, 52 p.

Fugro Earthdata, Inc., 2010, Lidar mapping fact sheet: 5 p., accessed January 10, 2010, at http://www.fugroearthdata. com/pdfs/FCT_Lidar-Educational_11-07.pdf.

Haag, K.H. and Lee, T.M., 2010, Hydrology and ecology of freshwater wetlands in central Florida-A primer: U.S. Geological Survey Circular 1342, 138 p. 
Haag, K.H., Lee, T.M., and Herndon, D.C., 2005, Bathymetry and vegetation in isolated marsh and cypress wetlands in the Northern Tampa Bay Area, 2000-2004: U.S. Geological Survey Scientific Investigations Report 2005-5109, 49 p.

Hancock, M.C., Rochow, T. F., and Hood, J., 2005, Test results of a proposed revision to the Wetland Assessment Procedure (WAP), October 2004, and development of the final wetland assessment methodology adopted in April 2005: Brooksville, Southwest Florida Water Management District report, $147 \mathrm{p}$.

Hutchinson, C.B., 1984, Hydrogeology of well-field areas near Tampa, Florida, Phase 2-Development and documentation of a quasi-three-dimensional finite difference model for simulation of steady-state ground-water flow: U.S. Geological Survey Water-Resources Investigations Report 84-4002, $174 \mathrm{p}$.

Hutchinson, C.B., 2003, Results of test-hole drilling in wellfield areas north of Tampa, Florida: U.S. Geological Survey Open-File Report 03-142, 38 p.

Johnston, R.H, Krause. R.E., and Meyer, F.W., Ryder, P.D., Tibbals, C.H. and Hunn, J.D., 1980, Estimated potentiometric surface for the Tertiary limestone aquifer system, southeastern United States, prior to development: U.S. Geological Survey Open-File Report 80-406, 1 sheet.

Kruse, S.M., Grasmueck, M., Weiss, M., and Viggiano, D., 2006, Sinkhole structure imaging in covered karst terrain: Geophysical Research Letters, v. 33, L16405, doi:10.1029/2006GL026975.

Lanesky, D.E., Logan, B.W., Brown, R.G., and Hine, A.C., 1979, A new approach to portable vibracoring underwater and on land: Journal of Sedimentary Petrology, v. 49 , p. $654-657$.

Lee, T.M., and Haag, K.H., 2006, Strength in numbers; describing the flooded area of isolated wetlands: U.S. Geological Survey Fact Sheet 2006-3118, 4 p.

Lee, T.M., Haag, K.H., Metz, P.A., and Sacks, L.A., 2009, The comparative hydrology, water quality, and ecology of selected natural and augmented freshwater wetlands in west-central Florida: U.S. Geological Survey Professional Paper 1758, $152 \mathrm{p}$.

Lee, T.M., Sacks, L.A., and Hughes, J.D., 2010, Effects of groundwater levels and headwater wetlands on streamflow in the Charlie Creek Basin, Peace River watershed, west-central Florida: U.S. Geological Survey Scientific Investigations Report 2010-5189, 77 p.

Marella, R.L., 2009, Water withdrawals, use, and trends in Florida, 2005: U.S. Geological Survey Scientific Investigations Report 2009-5125, 49 p.
McLain, D.H., 1974, Drawing contours from arbitrary data points: The Computer Journal, v. 17, p. 318-324.

Metz, P.A., Delzer, G.C., Berndt, M.P., Crandall, C.A., and Toccalino, P.L., 2007, Anthropogenic organic compounds in ground water and finished water of community water systems in the Northern Tampa Bay area, Florida, 2002-04: U.S. Geological Survey Scientific Investigations Report 5267, $48 \mathrm{p}$.

Metz, P.A., and Sacks, L.A., 2002, Comparison of the hydrogeology and water quality of a ground-water augmented lake with two non-augmented lakes in northwest Hillsborough County, Florida: U.S. Geological Survey Water-Resources Investigations Report 02-4032, 74 p.

Mitsch, W.J., and Gosselink, J.G., 2000, Wetlands: New York, Van Nostrand Reinhold, $920 \mathrm{p}$.

National Oceanic and Atmospheric Administration, 2010, What is an El Nino? Accessed January 11, 2010, at http:// www.pmel.noaa.gov/tao/elnino/el-nino-story.html.

Newton, J.G., 1986, Development of sinkholes resulting from man's activities in the Eastern United States: U.S. Geological Survey Circular 968, 54 p.

Pittman, C. and Waite, M., 2009, Paving paradise: Florida's vanishing wetlands and the failure of no net loss: Gainesville, University Press of Florida, 376 p.

Reiss, K.C., Hernandez, E., and Brown, M.T., 2009, Evaluation of permit success in wetland mitigation banking: A Florida case study: Wetlands, v. 29, no. 3 , p. 907-918.

Rochow, T.F., 1981, Cypress Creek hydrobiological monitoring: Brooksville, Southwest Florida Water Management District Technical Memorandum, February 18, 1991, $6 \mathrm{p}$. Also available at $h t t p: / / w w w 15 . s w f w m d . s t a t e . f l . u s /$ dbtw-wpd/exec/dbtwpub.dll.

Rochow, T.F., 1982, Biological assessment of the Jay B. Starkey Wilderness Park, 1982 update: Brooksville, Southwest Florida Water Management District Environmental Section Technical Report 1982-9, 76 p.

Rochow, T.F., 1983a, 1983 Photographic survey of the Jay B. Starkey Wilderness Park: Brooksville, Southwest Florida Water Management District Environmental Section Technical Memorandum 4-27-83, $56 \mathrm{p}$.

Rochow, T.F., 1983b, Vegetational monitoring at the Cypress Creek Wellfield, Pasco County, Florida, 1982 update: Brooksville, Southwest Florida Water Management District Environmental Section Technical Report 1983-2, 82 p. 
Rochow, T.F., 1983c, Sinkholes at the Cypress Creek well field: Brooksville, Southwest Florida Water Management District Technical Memorandum 83-1, $10 \mathrm{p}$. Also available at $h t t p: / /$ www15.swfwmd.state.fl.us/dbtw-wpd/exec/dbtwpub.dll.

Rochow, T.F., 1985a, Biological assessment of the Jay B. Starkey Wilderness Park, 1985 update: Brooksville, Southwest Florida Water Management District Environmental Section Technical Report 1985-4, 115 p.

Rochow, T.F., 1985b, Hydrological and vegetational changes resulting from underground pumping at the Cypress Creek Wellfield, Pasco County, Florida, Florida Scientist, v. 48, p. 65-80.

Rochow, T.F., 1998, The effects of water table level changes on freshwater marsh and cypress wetlands in the Northern Tampa Bay region-A review: Brooksville, Southwest Florida Water Management District Technical Report 1998-1, 60 p.

Rochow, T.F., and Bartos L.F., 1978, Biological assessment of the Jay B. Starkey Wilderness Park 1978 update with emphasis on water levels necessary to maintain biological conditions recommendations for preserving the present natural state during well field development: Brooksville, Southwest Florida Water Management District Environmental Section Technical Report 1978-4, 145 p.

Rochow, T.F., Bartos, L.F., and Schupp, E.W.,1976, Biological assessment of the Jay B. Starkey Wilderness Park with recommendations for preserving the present natural state during well field development: Brooksville, Southwest Florida Water Management District Environmental Section Technical Report 1976-4, 145 p.

Rochow, T.F., and K.R. Bradbury, 1978, Second year results of vegetational monitoring at the Cypress Creek Wellfield, Pasco County, Florida, 1976-77: Brooksville, Southwest Florida Water Management District Environmental Section Technical Report 1978-2, 85 p.

Rochow, T.F., and Rhinesmith, P., 1991, Comparative analysis of biological conditions in five cypress dome wetlands at the Starkey and Eldridge-Wilde well fields in southwest Florida: Brooksville, Southwest Florida Water Management District Environmental Section Technical Report 1991-1, $76 \mathrm{p}$.

Shepard, F.P., 1954, Nomenclature based on sand-silt-clay ratios: Journal Sedimentary Petrology, v.24, p. 151-158.

Shock, E.L., and Wilson, W.L., 1996, Sinkhole development in Hillsborough County, Florida: Subsurface Evaluations, Inc., 56 p., 3 app., 1 disk.
Sinclair, W.C., 1974, Hydrogeologic characteristics of the surficial aquifer in northwest Hillsborough County, Florida: Tallahassee, Florida Bureau of Geology Information Circular 86, $98 \mathrm{p}$.

Sinclair, W.C., 1982, Sinkhole development resulting from ground-water development in the Tampa area, Florida: U.S. Geological Survey Water-Resources Investigations Report $81-50,19 \mathrm{p}$.

Southeastern Geological Society, 1986, Hydrogeological units of Florida: Tallahassee, Florida Bureau of Geology Special Publication 28, 9 p.

Southwest Florida Water Management District, 1993, Computer model of groundwater flow in the Northern Tampa Bay area: Brooksville, Southwest Florida Water Management District report 249 p.

Southwest Florida Water Management District, 1996, Northern Tampa Bay water resources assessment project, volume 1: Surface-water/ground-water interrelationships: Brooksville, Southwest Florida Water Management District report, $468 \mathrm{p}$.

Southwest Florida Water Management District, 1999a, Northern Tampa Bay Phase II scope of work: Brooksville, Southwest Florida Water Management District report, 51 p.

Southwest Florida Water Management District, 1999b, Section 3.1 Palustrine Cypress Wetlands, in Report of the scientific peer review panel on the data, theories, and methodologies supporting the minimum flows and levels rule for the Northern Tampa Bay Area, Florida, August 3, 1999, 165 p.

Southwest Florida Water Management District, 1999c, Establishment of recovery levels in the Northern Tampa Bay area: Brooksville, Southwest Florida Water Management District report, $237 \mathrm{p}$.

Southwest Florida Water Management District, 2004, U.S. Fish and Wildlife Service, National Wetland Inventory data: Accessed July 1, 2007, at http://www.swfwmd.state.fl.us/ data/gis/libraries/physical_dense/nwi.htm

Southwest Florida Water Management District and Tampa Bay Water, 2005, Wetland Assessment Procedure (WAP) instruction manual for isolated wetlands, March 2005: Brooksville, Southwest Florida Water Management District report.

Southwest Florida Water Management District, 2008, The field identification guide to plants used in the Wetland Assessment Procedure (WAP), April 2008, (3d ed.): Brooksville, Southwest Florida Water Management District report, 57 p.

Southwest Florida Water Management District, 2009, Alternative water sources: Accessed February 10, 2010, at http://www.swfwmd.state.fl.us/publications/files/currents_ alternative.pdf. 
Southwest Florida Water Management District, 2010, Agricultural frost/freeze protection: Accessed April, 2010, at http:// www.swfwmd.state.fl.us/frost-freeze/Frost-Freeze-FAQs.pdf.

Stewart, M.T., and Parker, J., 1992, Localization and seasonal variation of recharge in a covered karst aquifer system, Florida, USA: International Contributions to Hydrogeology, v. 13, Springer-Verlag, p. 443-460.

Stewart M.T., and Stedje, D., 1990, Geophysical investigation of cypress domes, west central Florida: Report prepared by the University of South Florida, Department of Geology for the Southwest Florida Water Management District, Brooksville, January, 1990, 103 p.

Sumner, D.M., 2001, Evapotranspiration from a cypress and pine forest subjected to natural fires, Volusia County, Florida, 1998-99: U.S. Geological Survey Water-Resources Investigations Report 01-4245, 56 p.

Sumner, D.M., 2006, Adequacy of selected evapotranspiration estimates for hydrologic simulation: Journal of the American Water Resources Association, v. 42, no. 3, p. 699-711.

Tampa Bay Water, 2000, Environmental Management Plan for the Tampa Bay Water Central System well fields, Clearwater, Florida, 6 p.

Tampa Bay Water, 2004, Optimized regional operations plan annual report July 2004: Clearwater, Report prepared for Southwest Florida Water Management District, 36 p.

Tampa Bay Water, 2010a, Population: Accessed February 10, 2010, at http://www.tampabaywater.org/about/.

Tampa Bay Water, 2010b, Water-supply allocations: Accessed February 10, 2010, at http://www.tampabaywater.org/ supplies/.

Tihansky, A.B., 1999, Sinkholes, west-central Florida, in Galloway, D., Jones, D.R., and Ingebritsen, S.E., eds., Land Subsidence in the United States: U.S. Geological Survey Circular 1182, 177 p.

Tiner, R.W., 1984, Wetlands of the United States-Current status and recent trends: Washington, D.C., U.S. Fish and Wildlife Service Report, 59 p.

Tiner, R.W., 1999, Wetland indicators: A guide to wetland identification, delineation, classification and mapping: New York, Lewis Publishers.
U.S. Census Bureau, 2002, Florida: Population of counties by decennial census: 1900-1990, Forstall, R.L., ed.: Accessed September 29, 2004, at http://factfinder.census. gov/servlet/DatasetMainPageServlet?_lang=en\& $t s=114525133172 \& \_d s \_\% 20$ name $=\overline{D E C} \% 201990$ STF1_\&_program $=$.

Vecchioli, J., Tibbals, C.H., Duerr, A.D., and Hutchinson, C.B., 1990, Ground-water recharge in Florida-A pilot study in Okaloosa, Pasco, and Volusia Counties: U.S. Geological Survey Water-Resources Investigations Report 90-4195, $16 \mathrm{p}$.

Verdi, R.J., Tomlinson, S.A., and Marella, R.L., 2006, The drought of 1998-2002: Impacts on Florida's hydrology and landscape: U.S. Geological Survey Circular 1295, 34 p.

Watson, J., Stedje, D., Barcelo, M., and Stewart, M.T., 1990, Hydrogeologic investigation of cypress dome wetlands in well field areas north of Tampa, Florida: Proceedings of Focus Eastern Conference, Springfield, Massachusetts, October 17-19, 1990, National Water Well Association, Dublin, Ohio, p. 163-176.

Wentworth, C.K., 1929, A scale of grade and class terms for clastic sediments: Journal Sedimentary Petrology, v. 30, p. 377-392.

Wilson, W.L., and Garmen, M.K., 2002, Identification and delineation of sinkhole collapse hazards in Florida using ground penetrating radar and electrical resistivity imaging: Tampa, Florida, Subsurface Evaluations Inc., technical report: Accessed August 15, 2006, at http://www.dot.ca.gov/ hq/esc/geotech/gg/geophysics2002/114garman_sinkhole4. $p d f$.

Winter, T.C., Harvey, J.W., Franke, O.L., and Alley, W.M., 1998, Ground water and surface water: A single resource: U.S. Geological Survey Circular 1139, 79 p.

Yobbi, D.K., 2002, Testing the sensitivity of pumpage to increases in surficial aquifer system heads in the Cypress Creek well field area, west-central Florida-An optimization technique: U.S. Geological Survey Water-Resources Investigations Report, 20 p. 


\section{Appendixes 1-3}




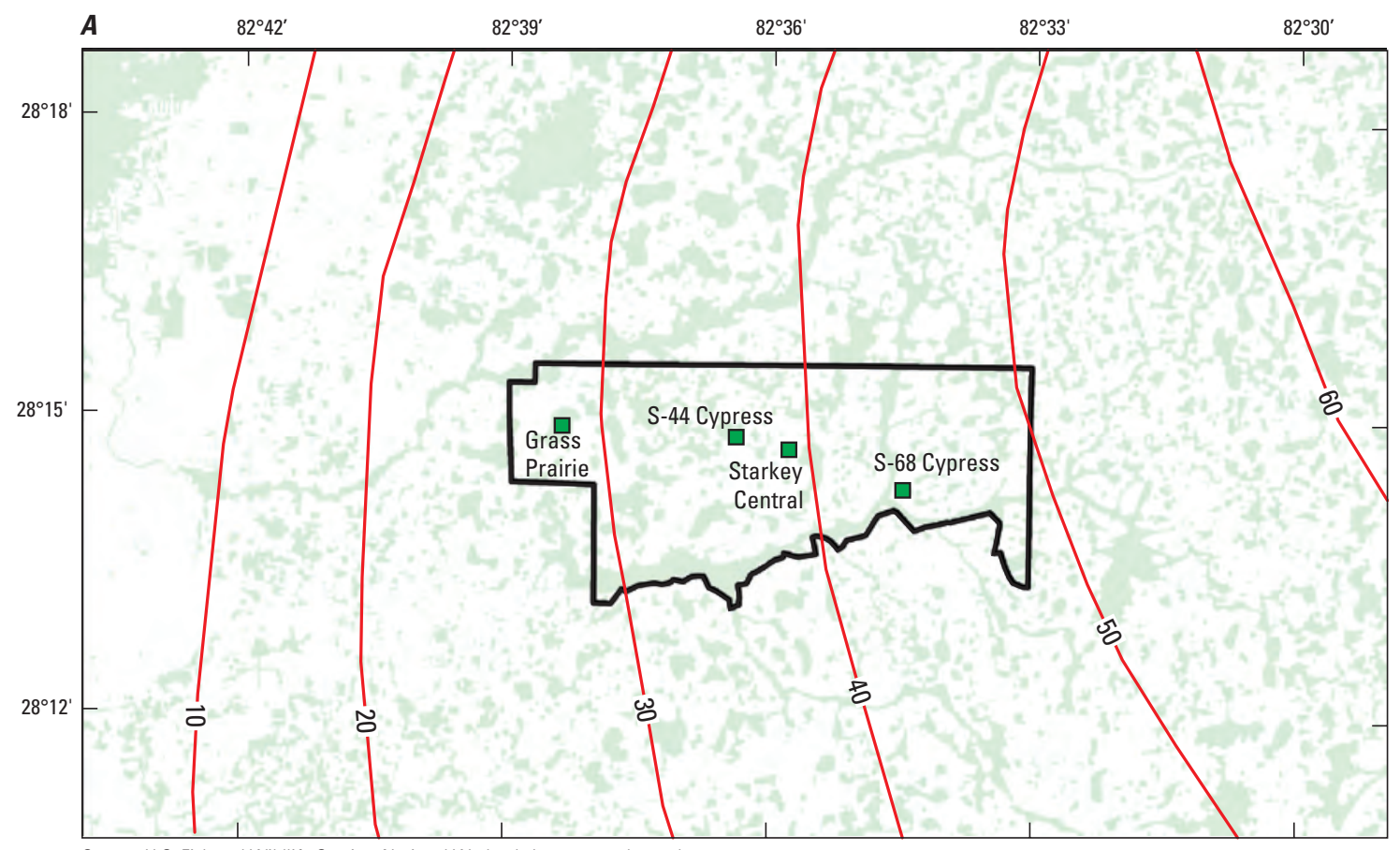

Source: U.S. Fish and Wildlife Service, National Wetlands Inventory polygon data, March, 2004; Universal Transverse Mercator projection, zone 17

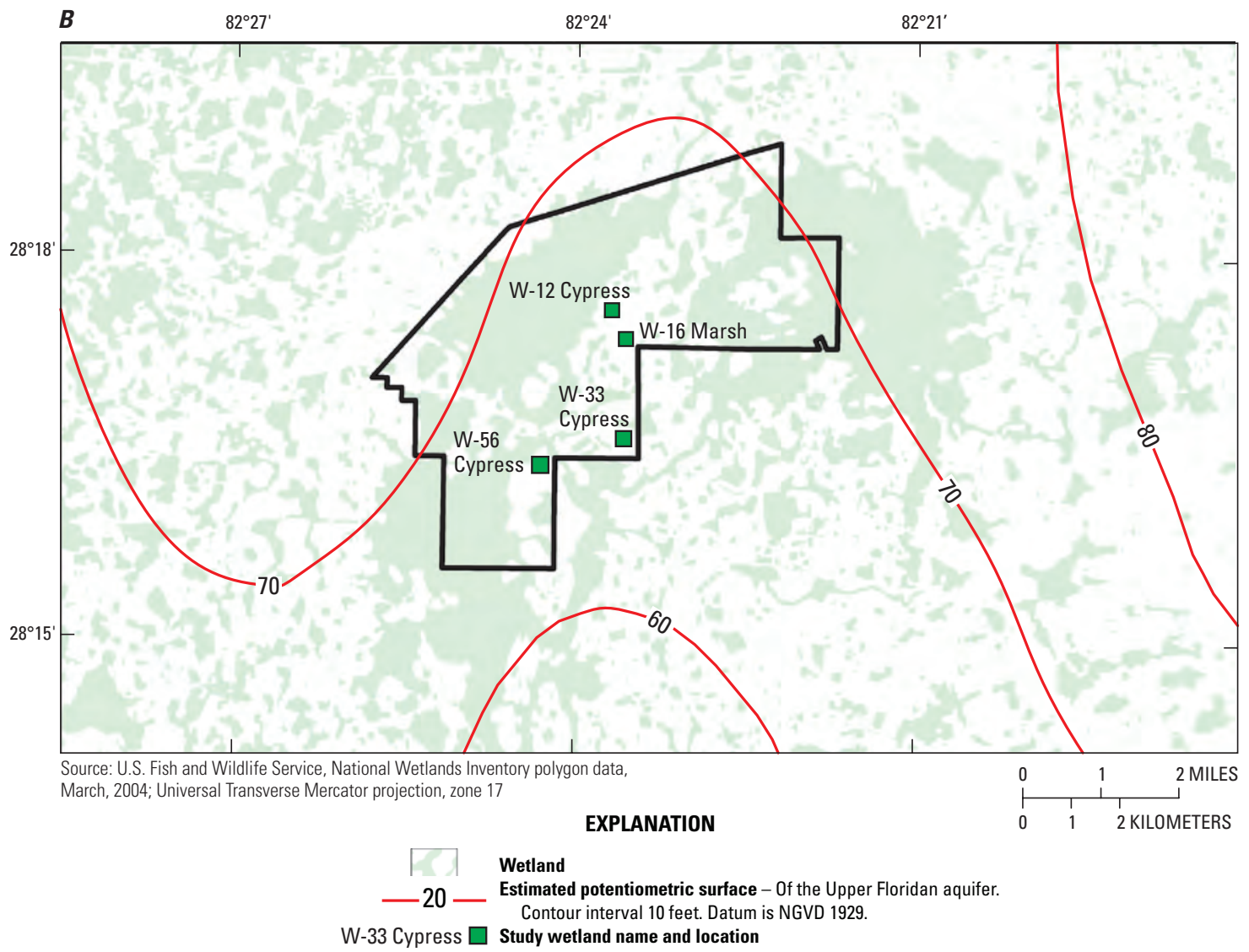

Appendix 1. Potentiometric surface map of the Upper Floridan aquifer prior to development at the $A$, Starkey, and B, Cypress Creek well fields. Modified from Johnston and others (1980). 

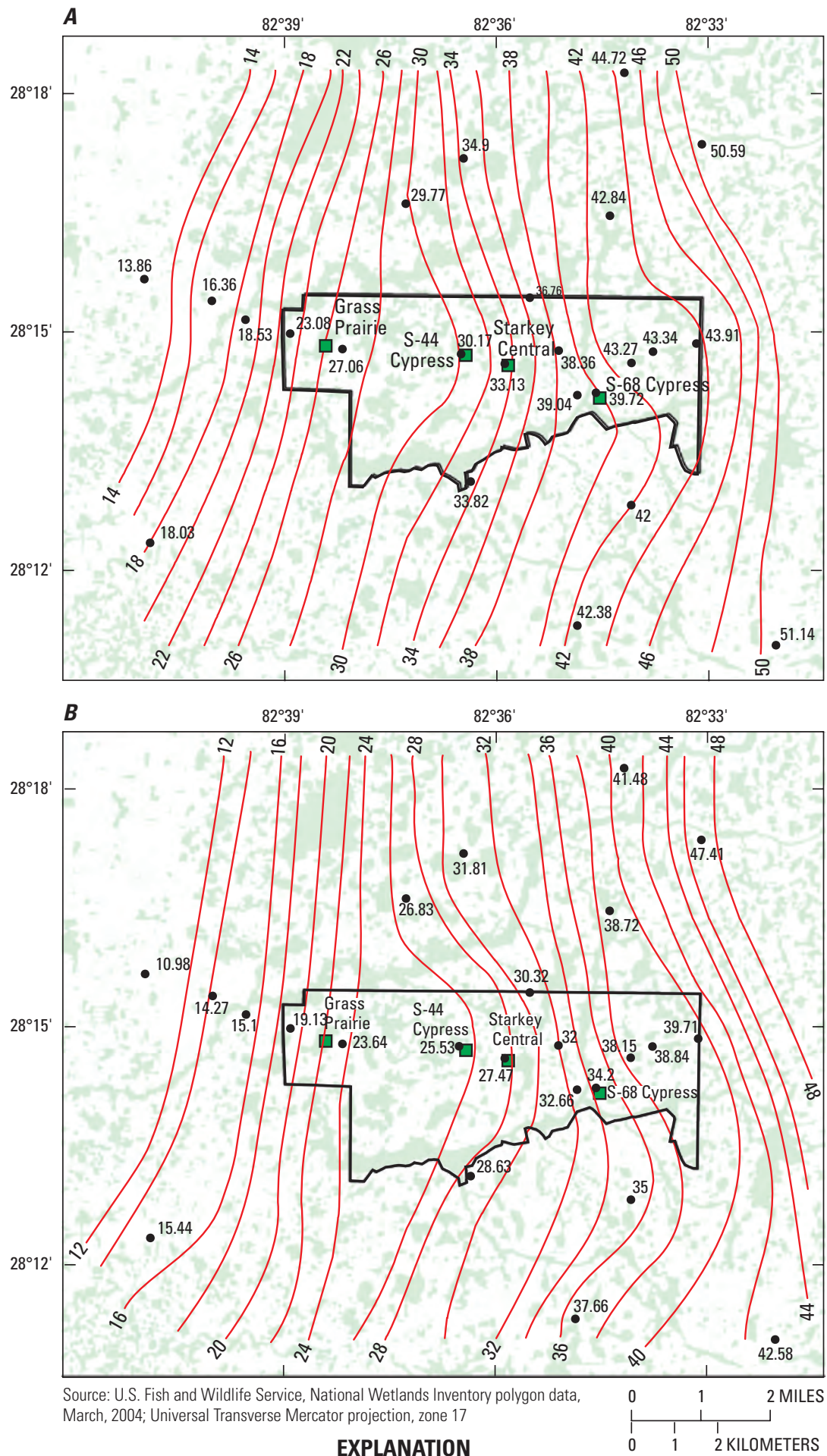

Well field

Well-field boundary

- 20- Potentiometric contour - Shows altitude at which water would have stood in tightly cased wells. Contour interval 2 feet. Datum is NGVD 1929.

15.440 Observation well and value

S-68 Cypress $\square$ Study wetland name and location

Appendix 2. Potentiometric surface map of the Upper Floridan aquifer at the Starkey well field for $A$, September 2008 and B, May 2009. 

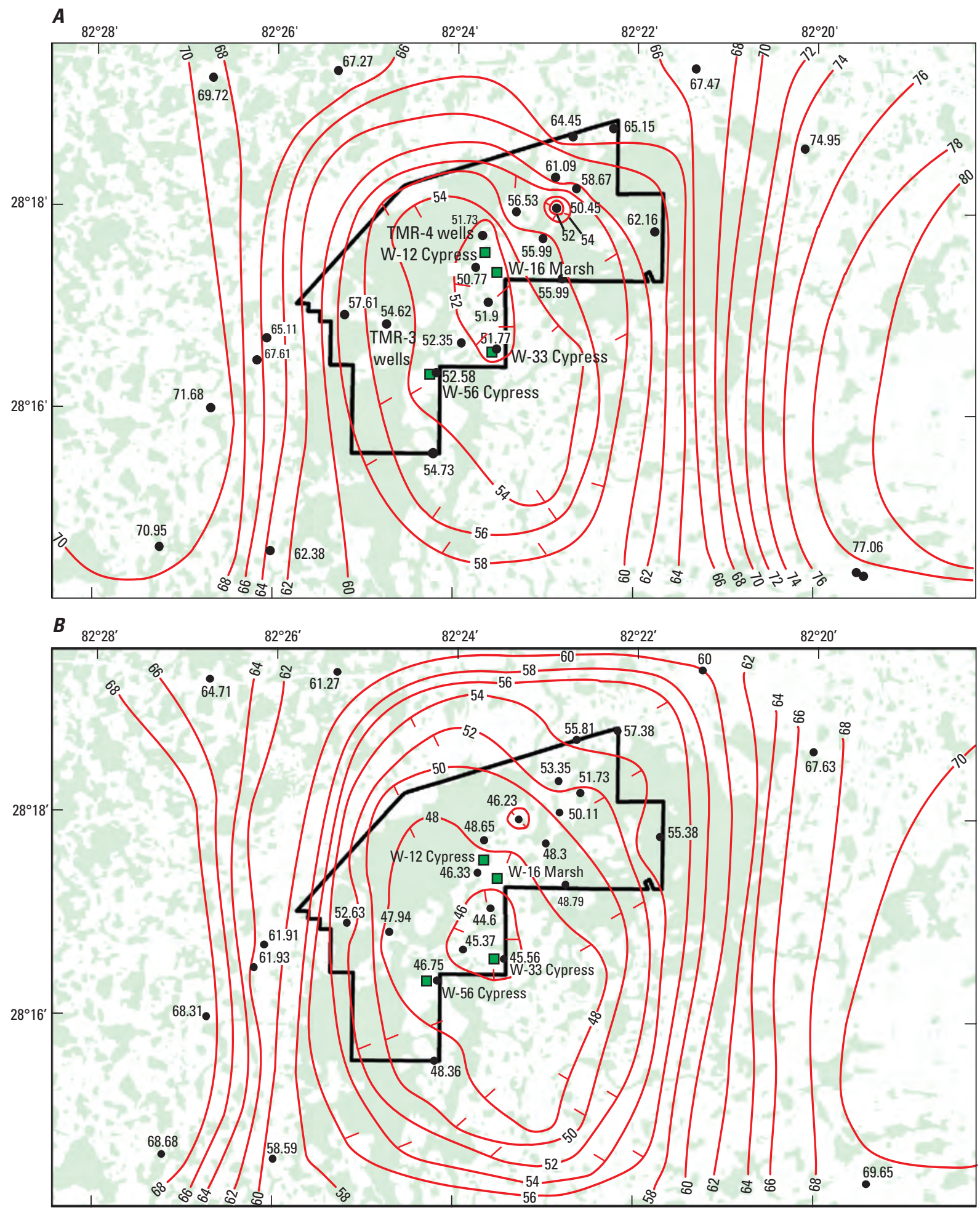

Source: U.S. Fish and Wildlife Service, National Wetlands Inventory polygon data, March, 2004; Universal Transverse Mercator projection, zone 17

EXPLANATION

- 20- Potentiometric contour - Shows altitude at which water would have stood in tightly cased wells. Hachures indicate depressions. Contour interval 2 feet. Datum is NGVD 1929.

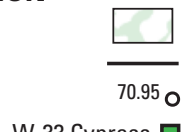

Well field

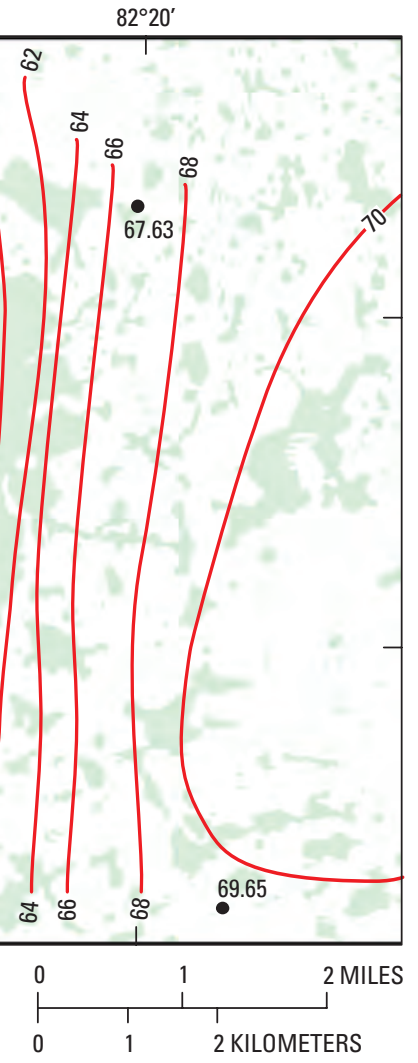

Well-field boundary

Observation well and value

W-33 Cypress $\square$ Study wetland name and location

Appendix 3. Potentiometric surface map of the Upper Floridan aquifer at the Cypress Creek well field for $A$, September 2008 and B, May 2009. 
Prepared by:

USGS Science Publishing Network

Raleigh Publishing Service Center

3916 Sunset Ridge Road

Raleigh, NC 27607

USGS publishing staff:

Mike Deacon, Editor

Ronald S. Spencer, Illustration assistance

For information regarding this publication, contact:

Director

USGS Florida Water Science Center

10500 University Center Dr., Suite 215

Tampa, FL 33612

http://fl.water.usgs.gov/ 
